$$
\text { USP - Universidade Estadual de São Paulo }
$$

Faculdade de Educação

Aldo Nascimento Pontes

\title{
A EDUCAÇÃO DAS INFÂNCIAS NA SOCIEDADE \\ MIDIÁTICA: DESAFIOS PARA A PRÁTICA DOCENTE
}

\section{Parte I}

São Paulo - SP 
USP - Universidade Estadual de São Paulo

Faculdade de Educação

Aldo Nascimento Pontes

\section{A EDUCAÇÃO DAS INFÂNCIAS NA SOCIEDADE \\ MIDIÁTICA: DESAFIOS PARA A PRÁTICA DOCENTE}

Tese de Doutorado apresentada à Faculdade de Educação da Universidade de São Paulo como requisito para obtenção do grau de Doutor em Educação - Área: Didática, teorias de ensino e práticas escolares.

Orientadora: Profa. Dra. Heloisa Dupas Penteado.

São Paulo - SP 


\section{Banca examinadora}

Profa. Dra. Elsa Garrido - FE-USP

Prof. Dr. Ismar de Oliveira Soares - ECA-USP

Profa. Dra. Tânia Maria Esperon Porto - UFPEL

Profa. Dra. Miriam Darlene Seade Guerra - UFMS

São Paulo - SP

2010 


\section{DEDICATÓRIA}

Ao encontro, porque como diz Gilles Lipovetsky (2009):

"Não há paixão sem encontros.

É essa situação que cria a paixão."

Especialmente à Prof ${ }^{a}$. Dra. Heloisa Dupas Penteado, pela oportunidade de beber da mesma fonte; e aos meus pais, Francisca e Luiz Pontes por, mesmo nas situações mais adversas, terem persistido em legar-nos a melhor educação que podiam. 


\section{AGRADECIMENTOS}

Tenho muito a agradecer e a muitas pessoas. Assim, não cito nomes para não correr o risco de ser injusto.

Agradeço ao glorioso pai Oxalá, aos guias e mensageiros de luz, às minhas duas famílias, daqui e de lá, às professoras e demais colaboradores da escola onde a pesquisa foi realizada, aos velhos e novos amigos que colaboraram direta ou indiretamente para a realização deste sonho, aos companheiros de jornada, alunos e professores que passaram por meu caminho, aos professores-pesquisadores que gentilmente fizeram a apreciação deste trabalho.

Com o tempo a gente aprende que a vida é mais fácil quando outros caminham ao nosso lado.

Em nome de minha gratidão, a todos vocês, ofereço as palavras a seguir...

\section{Das Utopias}

"Se as coisas são inatingíveis... ora Não é motivo para não querê-las... Que tristes os caminhos, se não fora A presença distante das estrelas!" (Mário Quintana) 


\section{EPÍGRAFE 1}

"Nuestro pensamiento nos ata todavía al pasado, al mundo tal como existía en la época de nuestra infancia y juventud. Nacidos y criados antes de la revolución electrónica, la mayoría de nosotros no entiende lo que ésta significa. Los jóvenes de la nueva generación, en cambio, se asemejan a los miembros de la primera generación nacida en un país nuevo. Debemos entonces reubicar el futuro. Para construir una cultura en la que el pasado sea útil y no coactivo, debemos ubicar el futuro entre nosotros, como algo que está aquí, listo para que lo ayudemos y protejamos antes de que nazca, porque de lo contrario sería demasiado tarde."

(MARGARET MEAD,1972). 


\section{EPÍGRAFE 2}

“Toda La televisión, todas las televisiones 'educan' aunque no se lo propongan.” "A La escuela no le queda alternativa; o entabla una alianza estratégica con la televisión y La asume intencionada y críticamente en todos los niveles, ámbitos y modalidades, 0 sucumbe como institución educativa." (GÓMEZ, 2001, p. 63 - 106). 


\section{EPÍGRAFE 3}

\section{O menininho 1}

Era uma vez um menino. Ele era bastante pequeno e estudava em uma grande escola. Mas, quando o menininho descobriu que podia ir à sua sala, caminhando, passando pelas portas, ele ficou feliz. E a escola não parecia mais tão grande quanto antes.

Uma manhã, quando o menininho estava na Escola, a professora disse:

- Hoje nós iremos fazer um desenho.

- Que bom! Pensou o menino. Ele gostava de fazer desenhos. Ele podia fazê-los de todos os tipos: leões, tigres, galinhas, vacas, barcos, trens; e ele pegou sua caixa de lápis e começou a desenhar. Mas a professora disse:

- Esperem! Ainda não é hora de começar. E ele esperou até que todos estivessem prontos.

- Agora - disse a professora - nós iremos desenhar flores.

- Que bom! Pensou o menininho. Ele gostava de desenhar flores. E começou a desenhar com seu lápis cor de rosa, laranja e azul. Mas a professora disse:

- Esperem! Vou mostrar como fazer. E a flor da professora era vermelha com caule verde.

- Assim! - disse a professora - Agora vocês podem começar.

Então ele olhou atentamente para a sua flor. Ele gostava mais de sua flor do que a da professora, mas não podia dizer isto. Ele virou o papel e desenhou uma flor igual à da professora. Ela era vermelha com caule verde.

Num outro dia, quando o menininho estava em aula, ao ar livre, a professora disse:

- Hoje nós vamos fazer alguma coisa com barro.

- Que bom! Pensou o menininho. Ele gostava de barro.

Ele podia fazer todos os tipos de coisas com barro: elefantes, camundongos, carros e caminhões. Ele começou a juntar e amassar a sua bola de barro. Mas a professora disse:

\footnotetext{
${ }^{1}$ Fizemos algumas adaptações à tradução encontrada na Internet no sentido de melhorar a sua coesão e coerência textuais. Versão original disponível em:

<http://revistaensinosuperior.uol.com.br/textos.asp?codigo=11137>. Acesso: 19/05/2009.
} 
- Esperem! Não é hora de começar. E ele esperou até que todos estivessem prontos.

- Agora! - disse a professora - nós iremos fazer um prato.

- Que bom! Pensou o menino. Ele gostava de fazer pratos de todas as formas e tamanhos. Porém a professora disse:

- Esperem! Vou mostrar como se faz. E ela mostrou a todos como fazer um prato fundo.

- Assim! - disse a professora. - agora vocês podem começar.

O menininho olhou atentamente para o prato da professora. Então olhou para o seu próprio prato. Ele gostava mais de seu prato do que o da professora. Mas não podia dizer isso. Então, ele amassou o seu barro numa grande bola novamente, e fez um prato igual ao da professora. Era um prato fundo.

Dessa maneira, muito cedo, o menininho aprendeu a esperar e a olhar, e a fazer as coisas exatamente como a professora. E muito cedo, ele não fazia mais as coisas por si próprio.

Então aconteceu que o menino e sua família mudaram-se para outra casa, em outra cidade, e o menininho tinha que ir para outra escola. E no primeiro dia em que ele estava lá, a professora disse:

- Hoje nós faremos um desenho.

- Que bom! Pensou o menininho. E ele esperou que a professora dissesse o que fazer. Mas a professora não disse. Ela apenas andava pela sala. Até que veio até ele e falou:

- Você não quer desenhar?

- Como posso fazer isso? Perguntou o menininho.

- Da maneira que você gostar. Disse a professora.

- De que cor? Perguntou o menininho.

- Se todo mundo fizer o mesmo desenho e usar as mesmas cores, como eu posso saber quem fez o quê? E qual o desenho de cada um?

- Eu não sei. Disse o menininho.

Foi então, que ele começou a desenhar uma flor vermelha com caule verde... (Helen E. Buckley) 


\section{RESUMO}

Neste estudo que compartilhamos com outros pesquisadores que reivindicam a urgência de uma educação, aos meios de comunicação e através da escola, sobretudo quando desenvolvida por meio de uma Pedagogia da Comunicação que, a partir de uma prática pedagógica mediadora e rica em comunicação escolar, seja potencializadora e possibilitadora de ações educativas dessa natureza. O contexto ao qual nos detemos é o da Educação Infantil. Isso se justifica por acreditarmos ser a infância o momento mais propício para que seja dado início a a educação para a mídia. Partindo dessas afirmações, a presente pesquisa tem por objetivo delinear saberes que possibilitem, aos professores da Educação Infantil, a construção de um conhecimento pedagógico (teórico-metodológico) que Ihes ofereça mecanismos para promoção de uma educação com, para e através de mídias já nessa modalidade de ensino, com as crianças pequenas. A natureza da pesquisa foi conduzida por uma pesquisa-intervenção, na modalidade pesquisa-ensino, com a qual buscamos, a princípio, identificar as concepções de infância dos sujeitos (professores) e posteriormente as possíveis influências da televisão na educação das crianças; subsequentemente, nos empenhamos em identificar saberes teóricos e metodológicos que poderiam contribuir para a formação desses professores, no sentido de uma educação com, para e através de mídias, em um processo de formação continuada. Os resultados dessa investigação evidenciaram, no início da pesquisa, que os professores - sujeitos da investigação - tinham dificuldade de conceber as crianças como produtoras de cultura, como sujeitos sociais agentes, com direito a voz e a participação social; não cultivavam uma cultura de planejamento eficaz de sua ação docente; manifestavam dificuldade de estabelecer uma intenção pedagógica clara em suas práticas docentes; e apresentavam uma carência significativa de saberes docentes que viabilizassem uma educação com, para e através de mídias conforme esboçamos. Ao final do processo de intervenção, uma vez oferecida a formação continuada, os professores desenvolveram habilidades para compreender as múltiplas representações da realidade, editaram mídias; passaram a atentar mais para a importância de se ter uma intenção pedagógica clara em sua prática pedagógica com, para e através de mídias; passaram a planejar melhor e oferecer atividades educativas ricas em comunicação escolar e com a participação ativa dos alunos; e por fim, sentiam-se seguros para formar indivíduos mais participativos, críticos e com um olhar mais sensível e vivencial da sociedade tecnológico-midiática na qual estão inseridos.

Palavras-chave: SOCIEDADE MIDIÁTICA, INFÂNCIA CONTEMPORÂNEA, CULTURA, EDUCAÇÃO INFANTIL, FORMAÇÃO DE PROFESSORES. 


\begin{abstract}
In this study we share with other researchers who claim the urgency of an education, to media and through school, especially when developed through a Pedagogy of Communication, from a pedagogical practice mediator and rich in communication school, is potentiate and an enabler of educational activities of this nature. The context in which we stop is the Early Childhood Education. This is justified because we believe childhood is the best time to be initiated this media education. Based on these assumptions, this research aims to delineate knowledge which enable teachers of early childhood education, construction of a pedagogical knowledge (theoretical and methodological) that provides them with mechanisms to promote an education for and through media that have type of education, with small children. The nature of the study was conducted by a research intervention, the research-teaching mode, with which we look, at first, identify the concepts of childhood subjects (teachers) and subsequently the possible influences of television in education of children, in a second, we strive to identify theoretical and methodological knowledge that could contribute to the training of these teachers, to an education, to and through media, in a process of continuous formation. The results of this investigation showed at the beginning of the research, teachers - research subjects - had difficulty conceiving children as producers of culture, as social agents, with voice and social participation, not cultivated a culture of effective planning of their teaching, demonstrating the difficulty of establishing a pedagogical intention clear in their teaching practices, and had a significant lack of teacher knowledge that ensure an education for and through the media as outlined. At the end of the intervention process, continuing education offered, teachers had developed skills to understand the multiple representations of reality, they edited media, began to attend more to the importance of having a pedagogical intention clear in their teaching practice, to and through media, began to plan better and offer richer educational activities in school and communication with the active participation of students, and finally felt safe to make subjects more participative, critical and a more sensitive and experiential society technology-media in which they belong.
\end{abstract}

Key-words: MEDIA SOCIETY, CHILDHOOD CONTEMPORARY, CULTURE, EARLY CHILDHOOD EDUCATION, TEACHER TRAINING. 


\section{ÍNDICE DE FIGURAS}

Figura 1: Retrato de três meninas

Figura 2: As meninas

Figura 3: Retrato do Príncipe Felipe Próspero

Figura 4: Retrato do príncipe Louis Joseph

Figura 5: A escada da vida humana ou As idades de vida

Figura 6: Dança camponesa

Figura 7: Festa de casamento 34

Figura 8: Os provérbios de Netherlandish ou o casaco azul 35

Figura 9: Nos jardins de Luxemburgo 35

Figura 10: $O$ balanço 36

Figura 11: O Biaro 39

Figura 12: Crianças brasileiras ficam mais de 19h na Internet /mês 39

Figura 13: Crianças americanas em loja da Rede Mc Donald's .... 40

Figura 14: Menina no subúrbio de Porto Príncipe 40

Figura 15: Adolescentes chineses dormem em sala na China ... 40

Figura 16: Crianças inglesas 40

Figura 17: Imagem da Campanha do refresco em pó Tang 56

Figura 18: Imagem da Campanha Internacional Semana Desligue a tevê . 68

Figura 19: Emei $A$ 105

Figura 20: Imagem aérea de localização da Emei A 106

Figura 21: Organograma Secretaria Municipal de Educação de Campinas-SP 107

Figura 22: Sala de aula 108

Figura 23: Secretaria, sala de tevê 108

Figura 24: Refeitório 108

Figura 25: Crianças brincando no Playground 109

Figura 26: Crianças brincando no Playground 109

Figura 27: Banheiro coletivo 109

Figura 28: Área onde guardam as mochilas 109

Figura 29: Área onde escovam os dentes 109

Figura 30: Disposição do playground, escola cercada pelo alambrado 109

Figura 31: Disposição do playground, escola cercada pelo alambrado 109

Figura 32: Encontro de formação pedagógica um 112

Figura 33: Conversa com a Profa . Dra. E. G. G 112

Figura 34: Conversa com a Prof ${ }^{a}$. Dra. E. G. G 
Figura 35: Alguns membros da Comunidade escolar do CMEI X ..................... 112

Figura 36: Reprodução de uma das páginas do diário de bordo da Pro.1........... 129

Figura 37: Cenas da reportagem Crianças do programa Fantástico ................... 131

Figura 38: Fotos das mochilas dos alunos da Pro.1 e da Pro.2 ......................... 136

Figura 39: Jogos infantis .......................................................................... 141

Figura 40: O triângulo semiótico de C. Ogden e I. Richards .............................. 150

Figura 41: A ponte de Langlois de Arles ................................................... 150

Figura 42: O quarto de dormir em Arles. ....................................................... 150

Figura 43: O homem amarelo ……....................................................... 150

Figura 44: O homem amarelo …............................................................ 150

Figura 45: A atriz Alessandra Negrini em cena do filme Cleópatra ..................... 151

Figura 46: Cena do filme Cleópatra …...................................................... 151

Figura 47: Jogos infantis ................................................................ 151

Figura 48: Torre de Babel ...................................................................... 151

Figura 49: Fotos feitas pela Pro.1, Rua em frente à escola................................ 152

Figura 50: Fotos feitas pela Pro.2, Rua em frente à escola............................... 152

Figura 51: Fotos feitas pelo segurança, Rua em frente à escola......................... 152

Figura 52: Algumas possibilidades de olhar o signo-símbolo vaca...................... 157

Figura 53: Emília criada pela Pro.1................................................................ 159

Figura 54: Desenhos feitos pelas crianças - história do Saci Pererê..................... 163

Figura 55: Desenhos feitos pelas crianças - história do Lobisomem.................. 164

Figura 56: Detalhe de um dos desenhos - história do Lobisomem...................... 166

Figura 57: Imagem do curta-metragem de animação Maria Flor ........................ 174

Figura 58: Ilustração capa DVD Maria Flor ..................................................... 183

Figura 59: Crianças fazendo desenho - animação Maria Flor ............................. 186

Figura 60: Desenhos das crianças - animação Maria Flor ................................. 187

Figura 61: Crianças fazendo teatro - animação Maria Flor ................................. 190

Figura 62: Divulgação do filme Kiriku e crianças assistindo .............................. 195

Figura 63: Disposição das crianças para assistir filme ..................................... 196

Figura 64: Ilustração capa DVD Smillingüido .................................................. 202

Figura 65: Trabalho a respeito das diferenças ............................................... 203

Figura 66: llustração capa DVD comédia Norbit .............................................. 204

Figura 67: Crianças confeccionando roletas ............................................... 221

Figura 68: Atividades do desenho do Chico Bento ............................................ 222

Figura 69: Ilustração capa DVD Pica-Pau ......................................................... 229

Figura 70: Exemplo de jogos de regras do Pica-Pau ........................................ 237 
Figura 71: Crianças brincando com o jogo do Pica-Pau ................................. 238

Figura 72: Festa de aniversário coletiva ..................................................... 240

Figura 73: Visita ao Zoológico de Americana ............................................... 240

Figura 74: Cartas das crianças na Festa do Papai Noel .................................. 241

Figura 75: Crianças recebem brinquedos na Festa do Papai Noel .................... 242

Figura 76: Crianças apreciando o filme feito com elas atuando ......................... 244

Figura 75: Reunião de pais e mestres, apreciação das atividades feitas ........... $\quad 245$ 


\section{SUMÁRIO}

\section{INTRODUÇÃO}

\section{CAPÍTULO I}

\section{Fundamentação Teórica}

1. A criança e sua educação: da infância moderna às infâncias contemporâneas

1.1 A concepção moderna de Infância: a hegemonia de uma Infância burguesa ........ 27

1.2 A Infância na contemporaneidade: Infâncias e Culturas da Infância ........................ 39

1.3 Cultura erudita, Indústria cultural e Cultura escolar: tecendo a teia ...................... 52

1.4 As Infâncias contemporâneas, educação com, para e através de mídias e formação de professores

\section{CAPÍTULO II}

\section{Metodologia}

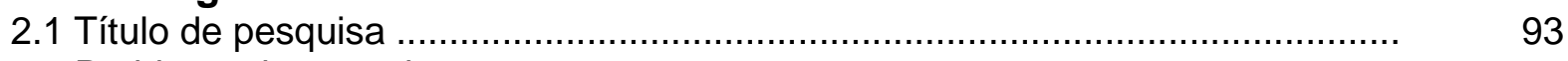

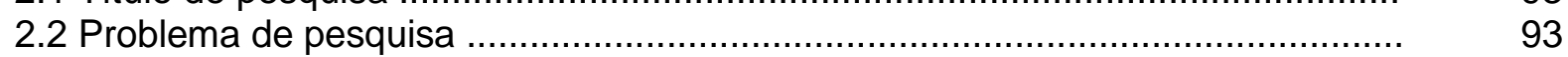

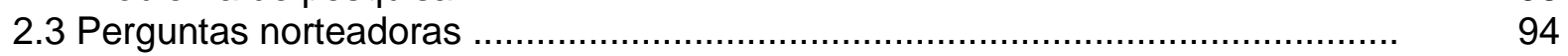

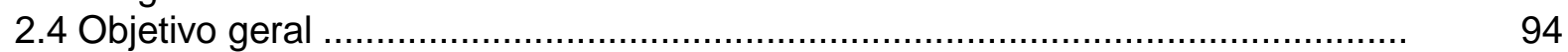

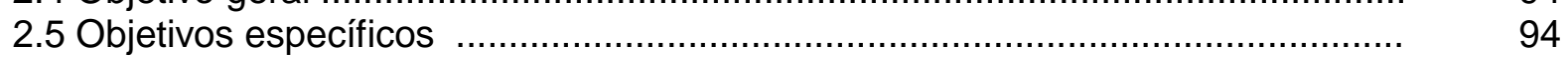

2.6 Instrumentos utilizados para coleta de dados ............................................... 95

2.7 Delimitação do local e dos sujeitos da pesquisa ................................................ 95

2.8 Procedimentos aplicados para coleta de dados ............................................ 96

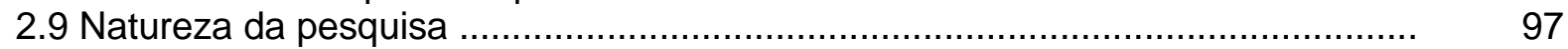

2.10 Caracterização do lócus da pesquisa ........................................................... 102

2.11 Caracterização dos sujeitos da pesquisa .................................................. 108

\section{CAPÍTULO III}

\section{Sobre os dados coletados}

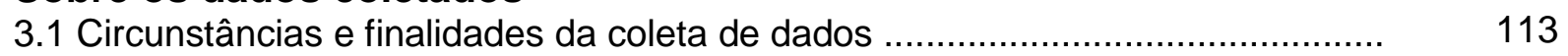

3.2 Quadro descritivo dos encontros realizados ............................................... 118

3.3 Natureza dos encontros ...................................................................... 121

\section{CAPÍTULO IV}

\section{Análise dos dados}

4 Exercício de ver, compreender e analisar: limites e perspectivas

4.1 Encontros de embasamento teórico e metodológicos

4.2 Encontros de construção de atividades pedagógicas

(sequências didáticas)

4.3 Encontros de avaliação

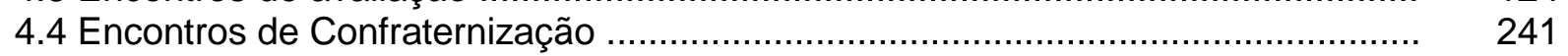

4.5 Encontros de Socialização . 
Considerações Finais

Referências

Anexos 


\title{
INTRODUÇÃO
}

Enfim, um individuo de ideias abertas.

\begin{abstract}
A coceira no ourido atormentava. Pegou o molho de chaves,
enfiou a mais fiminha na cavidade. Coscou de leve o pavilhaio, depois afundou no orificio enceradto. E rodou, virou a pontinha da chave em beatitude, a procura daquele ponto exato em que cessaria a coceira. Até que, traque, ouviu o leve estaloe, a chave enfim em seu encaixe, percebeu que a cabegal lentamente se abria.
\end{abstract}

(Xarina Colasanti, Contos de amor rasgados, 1986)

Escolhi apresentar a introdução desta pesquisa de doutoramento em primeira pessoa, e com esse pequeno conto de Marina Colasanti, em virtude representar para mim, com muita propriedade, a essência do exercício de certezas e incertezas que é o ato da pesquisa qualitativa.

A coceira que nos incomoda teve início ainda em nosso curso de formação inicial (Licenciatura em Letras - Universidade Federal do Pará - UFPA). Já naquele momento, enquanto muitos estavam preocupados em aprender e apreender os múltiplos sentidos da poesia, do conto, das literaturas, da linguagem, das artes..., sentia-me mais atraído pelas disciplinas da área de educação, como didática, história da educação, psicologia da educação etc. $O$ desafio de tornar-me professor em uma sociedade que se constitui cada vez mais complexa instigava-me um grande interesse pelos temas da educação.

Dentre os muitos temas da área educacional, acabei encontrando-me em dois: formação de professores e processos de ensino-aprendizagem. Esses me pareciam muito fascinantes, porém, com suas dimensões quase 'inabarcáveis', precisei buscar um ponto de encontro e diálogo entre eles, o que não foi muito difícil, pois comecei a observar como era 
comum a carência de diálogo entre os professores e (nós) alunos, fato que, muitas vezes, distanciava estes pares tão necessários à efetivação do processo educativo: faltava comunicação.

Foi com este olhar de quem acredita que quanto mais o professor proporcionar aos alunos situações que instiguem a trama das interações comunicacionais, mais educativa será sua prática pedagógica (KAPLÚN, 1999), que passei pela graduação, que fundamentei e dei início à minha prática pedagógica, que me especializei em didática da língua portuguesa e ingressei no mestrado em educação na Universidade Estadual de Campinas UNICAMP, onde meu interesse de investigação era verificar como se dava a formação de professores para o uso de tecnologias informáticas em sala de aula.

Ainda durante a realização da pesquisa de mestrado, também tive a oportunidade de iniciar minha carreira docente no ensino superior (2002), especificamente no curso de Pedagogia. Foi na vivência dessas duas experiências, uma de ser formado e outra de formar, que começou a se delinear o problema para o qual hoje busco respostas nesta pesquisa de doutoramento.

Isso se deu porque, enquanto no mestrado eu pesquisava o uso pedagógico de tecnologias informáticas pelos professores, cotidianamente os alunos do curso de pedagogia, especialmente nos trabalhos das disciplinas Educação e Comunicação e Informática na Educação, relatavam histórias ocorridas no interior da escola onde trabalhavam, da sala de aula, que frequentemente revelavam a dificuldade que eles (professores em formação inicial, alguns com o magistério médio) enfrentavam tanto em lidar com as influências que as crianças sofriam das mídias, principalmente da televisão, quanto em utilizar de forma pedagógica essa mídia na prática educativa. Situação que denunciava, às vezes inadvertidamente, sentimentos desta natureza:

"Sabe professor, eu acho que em alguns aspectos parece que a figura do professor não é tão atraente quanto a tevê. Lá as informações são rápidas e carregadas de imagens coloridas e atraentes, o que não acontece com a gente, né?! (professor). Há também o fato de que na tevê tudo vem pronto, não exige que a criança pense a respeito do que está sendo transmitido. Ah, eu é que não vou ficar dando atenção pra essas baboseiras que elas falam que viram lá. Dou minha aula, e pronto!".2

De início, isso me pareceu um tanto inusitado, pois entendia que em pleno século $\mathrm{XXI}$ as dificuldades dos professores em trabalhar com a programação e o consumo de tevê de forma pedagógica estivessem superadas. No entanto, com o tempo, verifiquei que isso era recorrente em outras turmas que vinham cursar as referidas disciplinas, e que apesar de todo o avanço tecnológico, e consequentemente das pesquisas a respeito da utilização de

\footnotetext{
2 Fala coletada em um dos encontros da disciplina Educação e Comunicação de uma instituição de ensino superior situada em Americana, 1ํ semestre de 2005.
} 
tecnologias na educação, o uso pedagógico da tevê e seus conteúdos na sala de aula ainda eram desafios para os professores, e mais ainda para os professorandos.

Com a finalização da pesquisa de mestrado e após cinco anos de observação dessas angústias dos professores que atuavam principalmente com as crianças da Educação Infantil, quando o assunto era a tevê como ferramenta educativa, resolvi me aprofundar, com olhos mais atentos, pelos caminhos que conduziam a pesquisar a relação educação e mídias ${ }^{3}$.

Das muitas histórias que ouvi durante aqueles anos, guardo até hoje algumas que foram extremamente impactantes na delineação de meu tema de pesquisa. A história do filho de 6 anos de uma aluna minha do curso de formação de professores que, estando em uma franquia do Mc Donald's, afirmou que ainda não sabia ler, mas sabia que seu nome (Matheus) começava com a mesma letra do nome daquela lanchonete; o fato ocorrido com o filho de 5 anos de uma aluna do curso de pós-graduação lato sensu que se mostrava orgulhosa por saber fazer um bom uso da tevê na educação, para provar sua habilidade, contava orgulhosa que diante da pergunta do filho sobre o que era sexo, não teve dúvida em colocá-lo sozinho para assistir a uma edição do Globo Repórter que tratou a respeito dessa temática, segundo ela, nunca se sentiu tão aliviada ao chegar em casa e a dúvida não mais existir; a da mãe que tirou a filha de 4 anos de uma escola pública municipal da Região Metropolitana de Campinas (RMC) porque a menina precisava de uma alimentação especial que não estava no cardápio das nutricionistas da escola: batatas Ruffles, biscoitos Trakinas e refrigerante Coca-Cola; a história da menina Amanda que aos seis anos vivia navegando por sites da Internet, sobretudo o da Barbie, e que ao ser solicitada que lesse o que estava escrito em uma caixa de biscoito, disse que só sabia ler e escrever no computador. Essas e muitas outras histórias só vieram comprovar uma suspeita levantada por Bucci (2002), Gómez (1990, 1997, 2001), Fischer (2007), Gonet (2004) quando afirmam que as crianças antes de irem para a escola já estão alfabetizadas pelas imagens veiculadas pelas mídias, em especial a televisão. Segundo esses autores, consumir, as crianças aprendem bem cedo, pois é sinônimo de ser alguém e ser feliz.

Essa experiência contribuiu decisivamente para que eu enveredasse por esta pesquisa. Nas últimas décadas, uma quantidade bastante expressiva de estudiosos das mais diversas áreas do conhecimento (educação, psicologia, filosofia, sociologia, psiquiatria...) vem se dedicando a compreender as implicações das mídias no processo educativo das crianças e adolescentes. O interesse desses estudiosos é comumente

\footnotetext{
3 Entendido neste trabalho como todo suporte de difusão da informação que constitui um meio intermediário de expressão capaz de transmitir mensagens. Assim, são meios de comunicação social de massas e interativos que abrangem os livros, o rádio, o cinema, a televisão, as revistas, os boletins, os jornais, o computador, o DVD, os celulares, o videocassete e outros (Houaiss, 2001).
} 
justificado pela ação cada vez mais ampla das mídias no cotidiano, influenciando crianças e adolescentes em diversos aspectos, inclusive em sua educação escolar.

Analisando parte das publicações que apresentam resultados dessas ações, é bastante recorrente os estudiosos apontarem a necessidade de uma educação com e para mídias na escola. Porém, a despeito dessa preocupação, o que chama a atenção nessas pesquisas é que, se por um lado alertam para a necessidade de os alunos do ensino fundamental e médio serem leitores e consumidores críticos da mídia, em particular a televisiva, por outro, poucos são os que dedicam suas pesquisas a pensar essa educação midiática já na Educação Infantil.

A impressão é de que se ignora aquilo que Gómez $(1997,2001)$ adverte quando afirma que, com a presença crescente e expansiva das mídias na vida cotidiana, instituições especificamente encarregadas da educação de crianças e jovens, como a família e a escola, são cotidianamente desafiadas a manterem-se significativas, pois: $O$ que se nos oferece $\mathrm{MCM}^{4}$ às crianças, independente do que consideremos valioso ou digno de ser oferecido a elas, está permitindo-lhes ter um conjunto de conhecimentos que Ihes são mais adequados para localizar-se e mover-se no mundo, em sua vida cotidiana (1997, p. 60). Essa suspeita é confirmada quando Gómez (1997), ao analisar pesquisas feitas a respeito da relação educação e comunicação, constata serem recorrentes resultados apontando que as crianças "[...] aprendem mais e mais rapidamente dos diversos meios de comunicação, e em especial da tevê, que do professor na escola". (p. 60).

Além disso, tem sido comum que os processos de formação de professores para esta ação, educação com e para mídias, ocorram sem levar em conta as concepções dos professores em relação às possíveis implicações das mídias na educação das crianças, o que acaba se constituindo em um grande equívoco, pois, ao serem considerados meros coadjuvantes, por vezes, nem são vistos como sujeitos, apenas "meros objetos de observação". Dessa forma, ao final desses processos de formação, poucas transformações são observadas no fazer pedagógico desses professores.

Isso se justifica pelo fato de os docentes pouco ou nada se sentirem tocados nos valores e crenças que trazem de suas vivências e experiências profissionais por esses processos de formação desenvolvidos com a intenção de melhorar a qualidade do trabalho docente, mas que, muitas vezes, além de estanques, limitam-se a validar aquilo que os professores já sabem.

Ao desconsiderar as concepções que os professores têm de infância, o que pensam sobre a função da escola na educação das crianças, como entendem as relações entre a criança, a escola, a sociedade e o seu processo de socialização, corre-se o risco de

\footnotetext{
4 Meios de Comunicação de Massa.
} 
contribuir para a legitimação de uma visão abstrata de criança e escola (MIRANDA, 1986). Agindo dessa maneira, a ação pesquisadora tende a cometer o equívoco de "[...] promover a integração de uma criança abstrata a uma sociedade harmônica, via processo de escolarização, essencialmente neutro." (p. 125). Assim, se o que se pretende é uma análise crítica da realidade, faz-se necessário atender para o caráter histórico e socialmente estabelecido tanto da infância como da educação oportunizada às crianças.

Entendo que em uma sociedade profundamente marcada pela ação de um processo de globalização capitalista que, em nome do consumismo, tende a naturalizar todos os aspectos da vida, inclusive a própria infância; e que tem as telas midiáticas como principal difusora e legitimadora de seus interesses, não há dúvida de que a escola precisa desenvolver uma educação com e para mídias que, por meio de uma Pedagogia da Comunicação, possibilite às crianças a participação ativa delas em seu processo de ensinoaprendizagem.

Educar, nesse contexto, constitui uma ação completamente diversa daquela que corriqueiramente encontramos em muitas escolas, nas quais, diante da ação da tevê no cotidiano das crianças, os professores acabam sendo obrigados a desenvolver atividades envolvendo a telinha sem nenhuma intenção pedagógica. Sendo assim, acabam fazendo uso da tevê de forma descontextualizada, utilizando-a apenas como uma ilustração de conteúdo previamente trabalhado ou simplesmente para 'matar o tempo', proporcionar lazer e relaxamento às crianças. Esse uso restrito ao instrumental dos meios na escola, além de estar distante do que se pretende com um processo educativo com e para os meios (MARTÍN-BARBERO, 2005), reafirma que, ainda hoje, a mídia televisiva é pouco aproveitada pelos professores em tarefas que permitam às crianças desenvolver um olhar vivencial, sensível e reflexivo a respeito do mundo que veem na tela dessa mídia.

Desconsidera a ação das mídias na educação escolar das crianças e negligenciar uma educação com, para e através das mídias na escola, além de uma atitude ingênua, tem consequências nocivas para própria instituição escolar:

\footnotetext{
Pode-se seguir tratando de desacreditar as aprendizagens realizadas fora da escola; pode-se legitimar os meios de comunicação como fontes reais de aprendizagem dos alunos; pode-se negar ou relativizar a influência deles, minimizá-la na fantasia e no discurso, e pode-se pretender ser mais 'poderoso' que eles; pode-se, enfim, repreender os alunos e seus pais por serem telespectadores tão adeptos e satanizar a TV, mas cabe perguntarse se essa é uma estratégia adequada para recuperar o lugar privilegiado (perdido?) na educação das crianças e jovens. (GÓMEZ, 1997, p. 63).
}

Essa indagação levantada por Gómez (1997) serve de advertência para um problema que certamente não será superado, condenando a escola e os professores. Afinal, antes de cobrarmos da escola e dos profissionais docentes uma educação com a para as 
mídias na escola, junto aos pequenos, precisamos averiguar se esses profissionais tiveram em sua formação inicial e/ou continuada acesso a saberes que lhes garantam fundamentos teóricos e metodológicos para uma educação dessa natureza.

É na perspectiva de contribuir para a superação dessa realidade mapeada até aqui que caminha esta tese de doutoramento. Cinco questões constituem nossa força movente:

1. Qual a concepção de infância dos professores de Educação Infantil?

2. Como esses compreendem possíveis influências da tevê, dentre outras mídias, na aprendizagem das crianças?

3. Que fundamentos teórico-metodológicos podem propiciar uma educação com e para mídia na Educação Infantil?

4. Como esses saberes teóricos podem contribuir para o desenvolvimento de metodologias que viabilizem uma educação nesse sentido?

5. De que forma uma educação com, para e através de mídias pode contribuir para o exercício da cidadania das crianças?

Aprendizagem, neste exercício de pesquisa, é compreendida com a base em uma abordagem construtivista sociocultural. À luz dessa abordagem, aprendizagem é um processo interno por meio do qual "[...] gradualmente compreendermos melhor o mundo em que vivemos e de sabermos melhor utilizar os recursos para nele agirmos." (ALARCÃO, 2003, p. 27). Caracterizada essencialmente como um processo de mudança de comportamento, a aprendizagem é imprescindível ao processo de construção do conhecimento, já que "[...] não há conhecimento sem aprendizagem" (p. 16). A aprendizagem é o engajamento transformador das formas de procedimento dos indivíduos.

Parto do suposto de que com os avanços tecnológicos verificados na atualidade, os processos comunicacionais merecerem outra leitura menos diretiva e mais complexa, passando a conceber a comunicação não mais como um processo linear caracterizado pela simples transmissão de informações de um sujeito (ativo) a outro (passivo), mas como transformação e construção cognitiva e emocional produzida por receptores e emissores com suas vidas inseridas no contexto social. Ainda hoje, e talvez mais do que nunca, penso que seria ingênuo pensar o consumo da tevê sem levar em consideração a ação exercida pela indústria cultural que está subjacente a ela, daí porque insistir na expressão influências da tevê sobre as crianças. Como bem alerta Penteado (1991, p. 49): "Em qualquer ordem social [...] o poder transformador da TV ocorre pelas contradições decorrentes dos interesses diversos dos agentes sociais compreendidos pela Indústria Cultural".

Ademais, uma educação escolar com e para mídias em muito pode contribuir para a superação de processos de socialização que segregam as crianças à condição de sujeitos passivos tanto na escola como na sociedade. Para isso, carecemos primeiro de um 
processo de formação que assegure ao professor saberes que possibilitem o entendimento de que, em primeiro lugar, "[...] 'a criança' não é uma categoria natural ou universal, determinada simplesmente pela biologia." (BUCKINGHAM, 2007, p. 19). Sendo assim, "O significado de 'infância' está sujeito a um constante processo de luta e negociação, tanto no discurso público (por exemplo, na mídia, na academia ou nas políticas públicas) como nas relações pessoais, entre colegas e familiares."

Em segundo lugar, resgatar o caráter dialógico do processo educativo por meio de uma Pedagogia da Comunicação no sentido de oportunizar, aos espaços escolares de comunicação e intercâmbio tanto entre professores e alunos, como entre os próprios professores e os próprios educandos, o diálogo entre esses sujeitos do processo educativo. Esse caminho é apontado por Penteado $(1999,2002,2006)$ que, com base nos estudos de Paulo Freire, fala-nos de uma prática pedagógica possibilitadora e potencializadora de ricas formas de socialização e participação ativa das crianças: a Pedagogia da Comunicação.

Com isso, centramos nossos esforços nesta tese em defender que, com professores capazes de compreender as múltiplas representações da realidade, editadas pelas mídias; estabelecer uma intenção pedagógica clara em sua prática pedagógica com, para e através desses meios; de planejar e oferecer atividades educativas com a participação ativa dos alunos; aptos a desenvolver uma prática docente que ressignifique a comunicação escolar restrita, uniltareal comumente praticada em sala de aula; pode-se em muito contribuir para a formação, já na Educação Infantil, de sujeitos mais participativos, críticos e com um olhar mais sensível e vivencial da sociedade tecnológico-midiática ora vivenciada,

A carta de navegação que nos orientou nesta jornada investigativa foi referendada pela abordagem da pesquisa-intervenção na modalidade pesquisa-ensino. Eleita como referencial por se tratar de uma metodologia em que o foco de investigação concentra-se no processo de ensino aprendizagem escolar; a ação interventora e investigadora se dá em um mesmo movimento; e se produz uma relação entre teoria e prática em que não há precedência de uma em relação à outra.

Os resultados deste trabalho de pesquisa são apresentados em cinco capítulos, os quais foram estruturados da seguinte forma:

No capítulo 1, busco delinear a Fundamentação Teórica em que me apoio. Nessa, tento abarcar a constituição da infância contemporânea, a educação escolar das crianças e a formação dos professores nessa sociedade. Além disso, conceituo o que entendo por educação com, para e através de mídias e, com base nos estudos de Penteado (1999 e 2002), a respeito da pedagogia da comunicação e da metodologia comunicacional de ensino, fundamentação teórica e metodológica para a construção de saberes que garantem a referida educação. 
O capítulo 2 dá lugar à Metodologia da Pesquisa. Nele trago os instrumentos e o percurso realizado para a coleta de dados, os objetivos e a natureza da pesquisa, a definição do lócus, a caracterização dos sujeitos da pesquisa e outros aspectos que concernem ao método que sustenta os procedimentos da pesquisa-intervenção.

Sobre os dados coletados é o título do capítulo 3, neste apresento as condições em que os dados foram recolhidos e o porquê desta escolha. Além de trazer um quadro síntese dos encontros realizados e um organograma indicativo da análise de dados.

Já o capítulo 4 dá lugar à Análise de dados, na qual concentro meus esforços em analisar os dados coletados à luz das ideias apresentadas na Fundamentação Teórica que traz os autores que orientam esta pesquisa.

Por último, apresento as Considerações Finais da Pesquisa que, mesmo consciente dos limites espaciais e temporais, buscou com seus resultados contribuir para as discussões a respeito da relação infâncias contemporâneas, formação de professores, pedagogia da comunicação e educação com e para mídias. Na sequência, elenco os livros e documentos que serviram de base e viabilizaram a pesquisa: a Bibliografia e os Anexos. 


\section{CAPÍTULO I}

\section{Fundamentação Teórica}

\section{A criança e sua educação: da infância moderna às infâncias contemporâneas}

Saiba: todo mundo foi neném Einstein. Freude Platão também Hitler, Bush e Saddam Hussein Quem tem grana e quem não tem Saiba: todo mundo teve infância Maomé já foi criança Arquimedes, Buda, Galileu. E também você e eu (Saiba - Arnaldo Antunes)

Ao iniciarmos este capítulo, que ousadamente busca pensar a infância e a educação das crianças ao longo dos tempos até os nossos dias, com letra tão habilidosamente composta por Arnaldo Antunes, o fazemos por ser uma canção que proporciona um questionamento chave para entendermos um pouco melhor o que é isto que identificamos como infância realmente. Pois, como diz a canção, por um lado, todos tiveram/têm infância; por outro, vale o questionamento ao se referir à infância em tempos, espaços, realidades e contextos diferentes: estamos falando sempre de uma mesma infância?

Tomamos esse questionamento como ponto de partida de nossa jornada, por estarmos convencidos de que compreender a infância hoje implica em conhecer os longos e complexos caminhos que ela percorreu ao longo dos tempos e espaços sociais. Assim, duas ressalvas nos parecem necessárias: primeiro a de que estamos conscientes dos limites de nosso tempo e olhar em busca de compreender o universo infantil; segundo, é que não 
buscamos, pretensiosamente, historiar a infância. Partindo dessas ressalvas, no intuito de atingir nossa meta de pesquisa, buscamos compreender alguns caminhos, acontecimentos, concepções e experiências chaves que implicaram/implicam diretamente na constituição desta categoria: infância.

Nossa incursão tem início na Idade Moderna. Isso se justifica por ser nesse momento que se deu a cisão entre o mundo adulto e o mundo infantil, condição imprescindível para o alicerçamento de um modelo de infância que perdurou ao longo dos tempos, e se tornou referência na atualidade para a compreensão da infância das crianças contemporâneas. Além disso, é nesse momento que indubitavelmente temos um modelo de infância com contornos bem definidos, condição relevante para este exercício de pesquisa.

\subsection{A concepção moderna de Infância: a hegemonia de uma Infância burguesa}

\footnotetext{
As sociedades centralizaram sempre o saber, porque o saber foi sempre fonte de poder, desde os sacerdotes egípcios aos monges medievais ou, atualmente, aos assessores dos políticos. Dos mosteiros medievais às escolas de hoje, o saber conservou esse duplo caráter de ser, ao mesmo tempo, centralizado e personificado em figuras sociais determinadas (XIRTIN-BARBERO, 2000, p. 54).
}

A consolidação de um sentimento moderno burguês de infância, que surgiu no final da Idade Média e início da Idade Moderna, sobretudo como consequência do surgimento da imprensa (por volta de 1439) e da quebra do monopólio do conhecimento por parte da Igreja, o que também possibilitou a popularização dos livros e o ressurgimento das escolas, gerou reações que desencadearam dois outros sentimentos em relação à infância: a "paparicação" e a sua "moralização". 


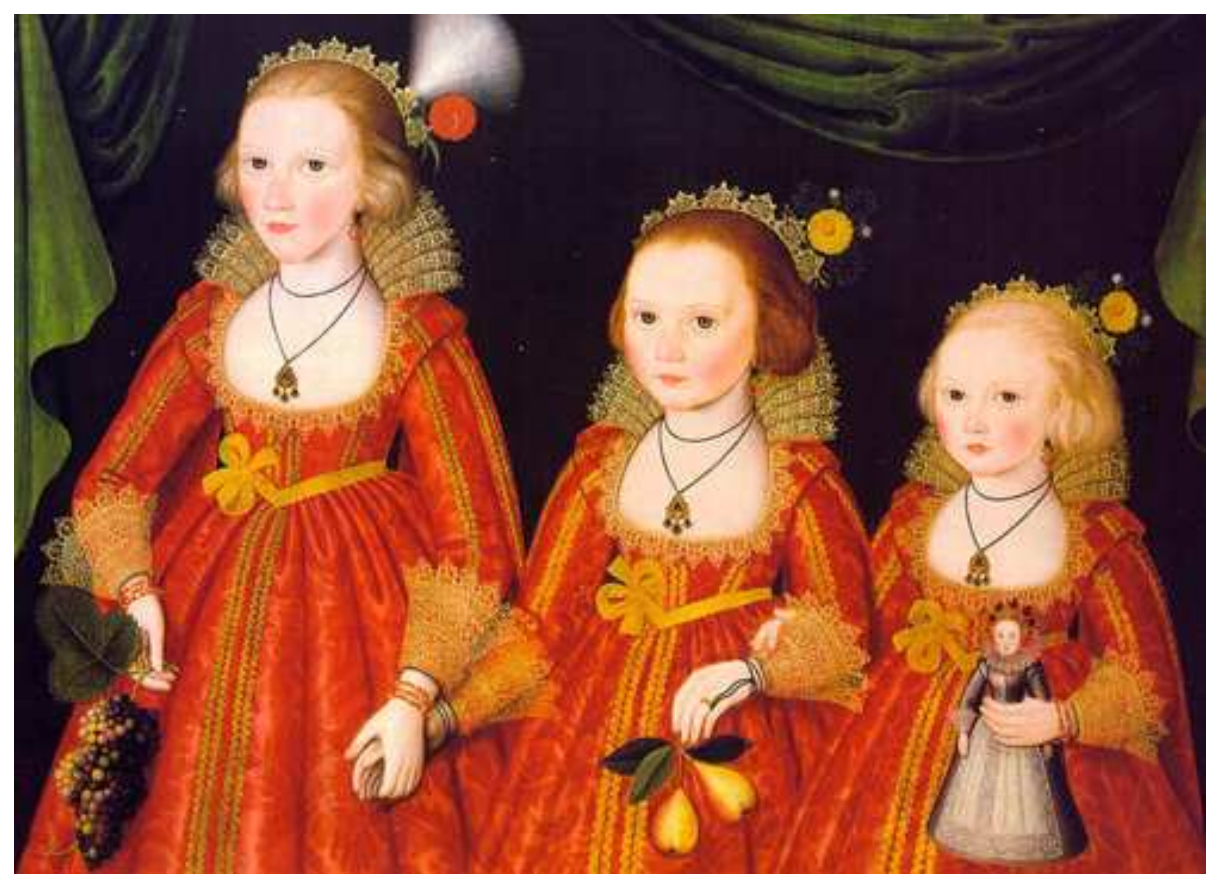

Figura 1: Uma representação de um mundo e um tempo em que não havia muito espaço para as crianças serem crianças. Na tela de Robert Peake, Retrato de três jovens meninas, do início do século XVII, os trajes e acessórios pouco ajudam a distinguir as crianças dos jovens e dos adultos. ${ }^{5}$

Inicialmente impregnada pelo sentimento infância vigente na época, a sociedade moderna burguesa, que paulatinamente convencia-se de que as crianças tinham natureza e necessidades diversas das dos adultos, passou a concebê-las como seres caracterizados pela ingenuidade, pela inocência, pela gentileza, pela singeleza, pela graça..., concepções que desencadearam o sentimento cunhado por Ariés (1981) de "paparicação". Esse autor ressalva que paparicar as crianças já era um hábito comum, mas somente entre as mães e/ou amas de leite. "De agora em diante, (na modernidade) porém as pessoas não hesitariam mais em admitir o prazer provocado pelas maneiras das crianças pequenas, 0 prazer que sentiam em 'paparicá-las'," "[...] fonte de distração e relaxamento para o adulto". (p. $158-101)$.

Um dos fatores que implicou sobremaneira para essa nova forma de conceber a infância foi o surgimento de outro sentimento de família diverso do experienciado na Idade Média e início da Idade Moderna, quando as crianças, mesmo recebendo alguns cuidados e sendo protegidas por seus pais, não encontravam na instituição familiar um sentimento fraternal que unisse emocionalmente aqueles que constituíam esta instituição.

Um bom exemplo desse sentimento é o que encontramos na tela As meninas de Velásquez:

\footnotetext{
${ }^{5}$ Disponível em: 〈http://aleyma.tumblr.com/post/1980840020/follower-of-william-larkin-three-young-girls〉. Acesso em: 12 mai., 2009.
} 


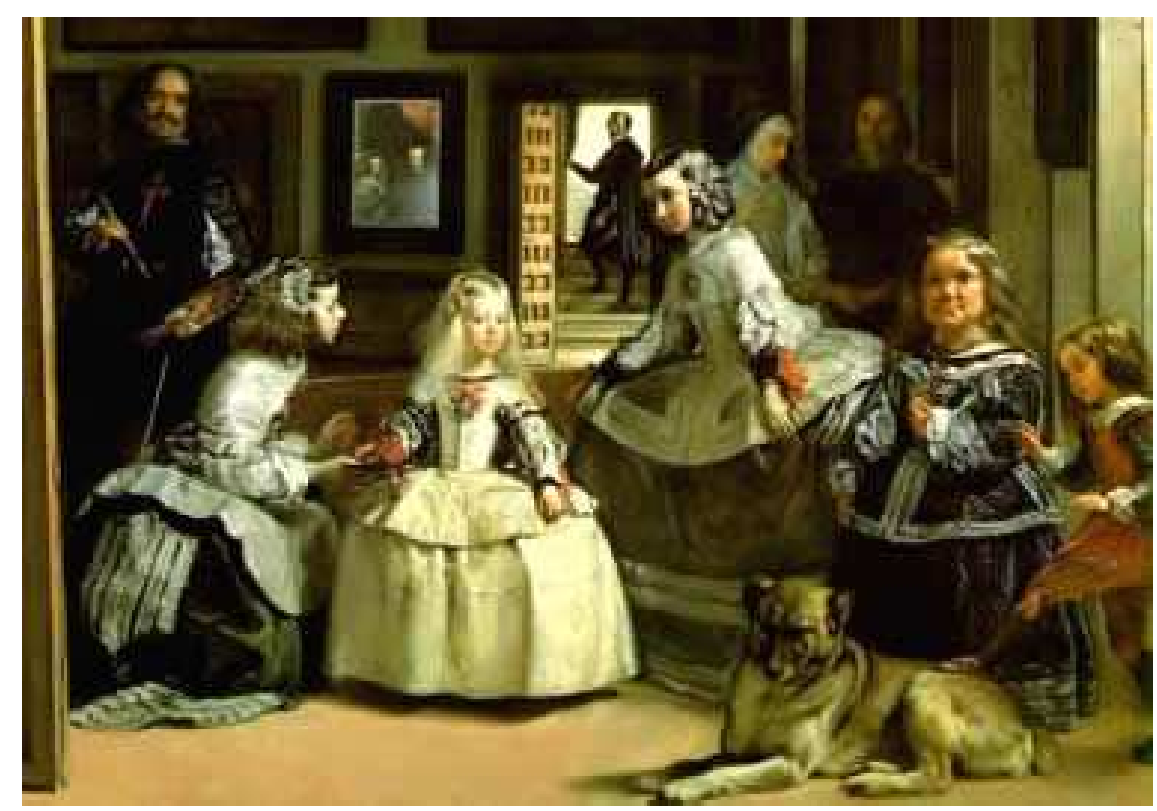

Figura 2: Tela As meninas (ao centro Infanta Margarita), Diego da Silva Velásquez, Madrid, 1656 - Uma possível representação do sentimento de paparicação, a família reunida em torno da criança. ${ }^{6}$

Porém, a concepção moderna burguesa de infância, que via a criança como um ser que merece paparicação, desencadeou também, por parte dos eclesiásticos legisladores (educadores moralistas da época, representantes da Igreja Católica), uma forte reação que resultou em outro sentimento em relação às crianças: um julgamento moral da infância. Esse outro sentimento execrava a paparicação dedicada a elas, pois, para os eclesiásticos, mais que seres encantadores, as frágeis, singelas e inocentes criaturas eram de Deus e que, por isto, precisavam ser preservadas, disciplinadas, educadas na moral e nos bons costumes pregados pela Igreja e pelo Estado. Desse modo, essas duas instituições acabaram reivindicando para si o controle da educação escolar pública infantil, ato que representou um primeiro passo para também controlar a vida privada do homem moderno.

Um olhar mais atento para essa maneira maniqueísta de conceber a infância: ora entendidas como anjos, ora como demônios, revelava já o início de um processo de naturalização da infância e a negação de sua constituição histórica e social. Para Miranda (1986), a negação da infância enquanto também uma constituição social e a sua percepção apenas como uma fase natural da vida, além de justificar as concepções comuns sobre a criança, acaba exercendo uma função ideológica, à medida que mascara a desigualdade social existente entre crianças e adultos. Sobretudo por ser essa última, um sujeito à margem do processo de produção, condição supervalorizada nas sociedades capitalistas. É essa ideia de infância, desprovida de fundamento histórico e contexto social identificada

\footnotetext{
${ }^{6}$ Disponível em: < http://www.sabercultural.org/template/obrasCelebres/AsMeninas.html>. Acesso em: 13 jan., 2008.
} 
pelo autor, que irá perdurar ao longo dos tempos e chegar aos nossos dias como uma concepção eterna, universal e natural.

O princípio da revelação da verdade, herdado da antiguidade clássica e da subordinação do pensamento filosófico ao ensinamento religioso cristão, praticado desde o início dos tempos medievais, foi a base da doutrina escolástica responsável pela educação e doutrinação das crianças, fundamento que perdurou por toda a Idade Média e boa parte da Idade Moderna. A respeito disso, Narodowski (2001, p. 50) considera em seus estudos que "[...] O corpo infantil, por sua vez, não adquire seus traços definitivos a não ser a partir da escolarização." Ademais, a educação escolar também passou a influenciar a duração da infância, conforme aprendemos com Ariés (1981, p. 191): "A criança, enquanto durava a sua escolaridade, era submetida a uma disciplina cada vez mais rigorosa e efetiva, e essa disciplina a separava da liberdade do adulto. Assim, a infância era prolongada até quase toda duração do ciclo escolar".

A respeito das formas de educar as crianças praticadas pelos representantes da Igreja, Veiga (2004) nos ensina que estas foram prescritas na direção dos "[...] castigos morais, da exposição, do vexame público e da formação do sentimento de vergonha. Outra orientação curricular praticada pelos educadores eclesiásticos era a formação das civilidades, condenando os "mimos", porque amolecem a alma e o corpo dos indivíduos" ( $p$. 46).

Até o final da Idade Média e início da Idade Moderna, a infância permaneceu sendo considerada uma fase de perdição e confusão: "[...] ela continua sendo o território primordial e essencial do erro, do preconceito, da crença cega, todos esses vícios do pensamento dos quais devemos nos libertar." (GAGNEBIN, 1997, p. 89). Dessa forma, era considerada uma fase infeliz da qual dever-se-ia livrar as crianças o quanto antes. O caminho para isso então era oportunizar a elas "[...] condições propícias ao crescimento rápido da luz natural da alma, do nous ${ }^{7}$ platônico, da razão cartesiana, para enfim tornarem-se adultos." (p. 90).

De acordo com Dornelles (2005), a nova concepção de infância que se edificou na modernidade trouxe em seu bojo uma série de práticas que visavam estabelecer ações de cuidado com o infantil. Com isso também legitimou a dependência das crianças e o controle dos adultos sobre elas. Consequentemente, pelas mãos dos eclesiásticos conservadores, as crianças foram sendo enclausuradas em instituições e cerceadas em sua liberdade característica do universo infantil.

\footnotetext{
7 De acordo com o Dicionário Houaiss (2001), nous platônico é a faculdade humana capaz de captar verdades fundamentais por uma via intuitiva, em oposição aos limites apresentados pelo pensamento meramente calcado na ciência e na discursividade; essa expressão é também sinônimo de intelecto.
} 
Nas palavras dessa autora:

Para com a criança nobre há uma exigência de docilidade que a educação escolar produzirá: um ser dócil que pode ser controlado, manipulado e domesticado. Toda a forma de atendimento às crianças, e não só à criança nobre, todo o controle e vigilância, ou seja, todas as formas de governo dos infantis que se produziram a partir daí, se constituem em condições de possibilidade para a institucionalização e escolarização massiva da infância no século XIX, transformando-a em uma criança razão. (DORNELLES, 2005, p. 33).

A emergência dessa outra ideia de infância aliada ao avanço das descobertas científicas e a consequente preocupação dos adultos com a higiene e a saúde física das crianças contribuiu decisivamente para a edificação de uma nova perspectiva em relação à vida, segundo a qual, a família-tronco que ocupava o espaço público e que vivia constantemente preocupada com perpetuação da linhagem (GÉLIS, 1998), dá lugar a um modelo burguês de família, a qual, enclausurada no espaço do privado, passa a organizarse em torno do universo infantil.
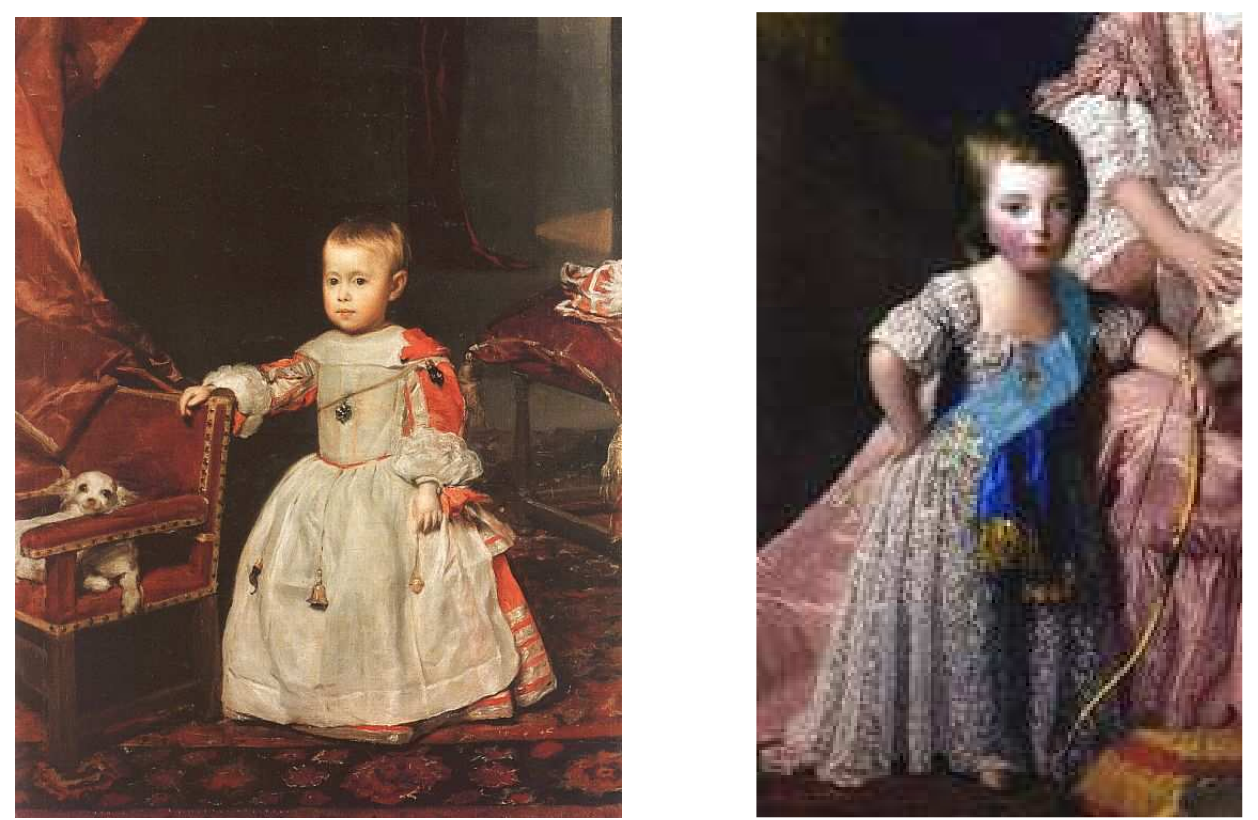

Figura 3: À esquerda: Tela Retrato do Príncipe Felipe Próspero, Diego da Silva Velásquez, 1659.8

Figura 4: À direita: Tela Detalhe do Retrato do príncipe Louis Joseph (Filho da Rainha Maria Antonieta), Elisabeth Vigée-Lebrun, 1787. - Representações da infância no espaço do privado. Na figura 3, a infância denunciada pelos guizos nas vestes do príncipe, pela cortina desarrumada e pelo cachorro sobre a poltrona, detalhes não aceitáveis a um adulto da época e condição social. Na figura 4, faixa azul e arco e flecha simbolizam a infância do príncipe Louis Joseph. ${ }^{9}$

\footnotetext{
${ }^{8}$ Disponível em: <

<http://upload.wikimedia.org/wikipedia/commons/f/fd/Retrato_del_pr\%C3\%ADncipe_Felipe_Prospero\%2C_by _Diego_Vel\%C3\%A1zquez.jpg>. Acesso em: 02 fev., 2008.

${ }_{9}$ Disponível em: < http://my.opera.com/Lux\%C3\%BAria/blog/?id=4339456>. Acesso em: 02 fev., 2008.
} 
Os ideais iluministas surgidos na França no século XVII, que propunham o predomínio do pensamento racional a respeito do teocentrismo e que inspiraram e suscitaram uma série de revoluções burguesas, que culminaram na Revolução Francesa (1789-1799), contribuíram decisivamente para o surgimento de leis que reconheciam as crianças como seres de direito e que careciam de proteção legal e cuidados específicos e diferenciados. Em decorrência disso, logo despontaram áreas profissionais especializadas no tratamento infantil, como a pediatria, a psicologia infantil, a puericultura, a pedagogia e outras. Além dos cuidados, essas áreas também passaram a estudar o comportamento infantil no sentido de compreender a criança como um todo. Vale o registro, cada uma com seus referenciais teóricos.

De acordo com Gélis (1998), a principal mudança nesse momento é a separação do corpo físico, individual, pessoal do corpo coletivo. Em outras palavras, reivindicava-se a individualidade de cada um. Isso traz mudanças significativas na relação dos adultos com as crianças. Os pais já não aceitavam mais com naturalidade a perda precoce de seus filhos, como ocorreu durante quase toda a Idade Média $^{10}$, recusando assim as doenças e cuidando melhor deles para que não perecessem.

Durante quase toda a idade Média, a mortalidade infantil foi vista como algo natural, era perfeitamente aceitável, tolerável, normal. Era comum a morte prematura. Acreditava-se que "[...] a terra-mãe estava na origem de toda forma de vida: era um viveiro inesgotável que assegurava a renovação das espécies. [...] Cada indivíduo [...] saía da terra através da concepção e a ela voltava através da morte." (GÉLIS, 1998, p. 319). Pistas deixadas por Ariés (1981), Gélis (1998), dentre outros pesquisadores, permitem inferir que, para o homem medieval, as crianças sequer tinham alma. Dessa forma, se um filho viesse a falecer, naturalmente seria substituído por outro que viria a nascer. A criança muito pequenina, demasiado frágil ainda para se misturar à vida dos adultos, "não conta" (ARIÈS, 1981, p. 99).

\footnotetext{
10 Quando predominava uma visão naturalista da vida: Do pó vieste, ao pó voltarás. Independia o tempo de vida que a pessoa vivesse, pois, acreditava-se que após a morte, logo o indivíduo voltaria em um novo corpo.
} 


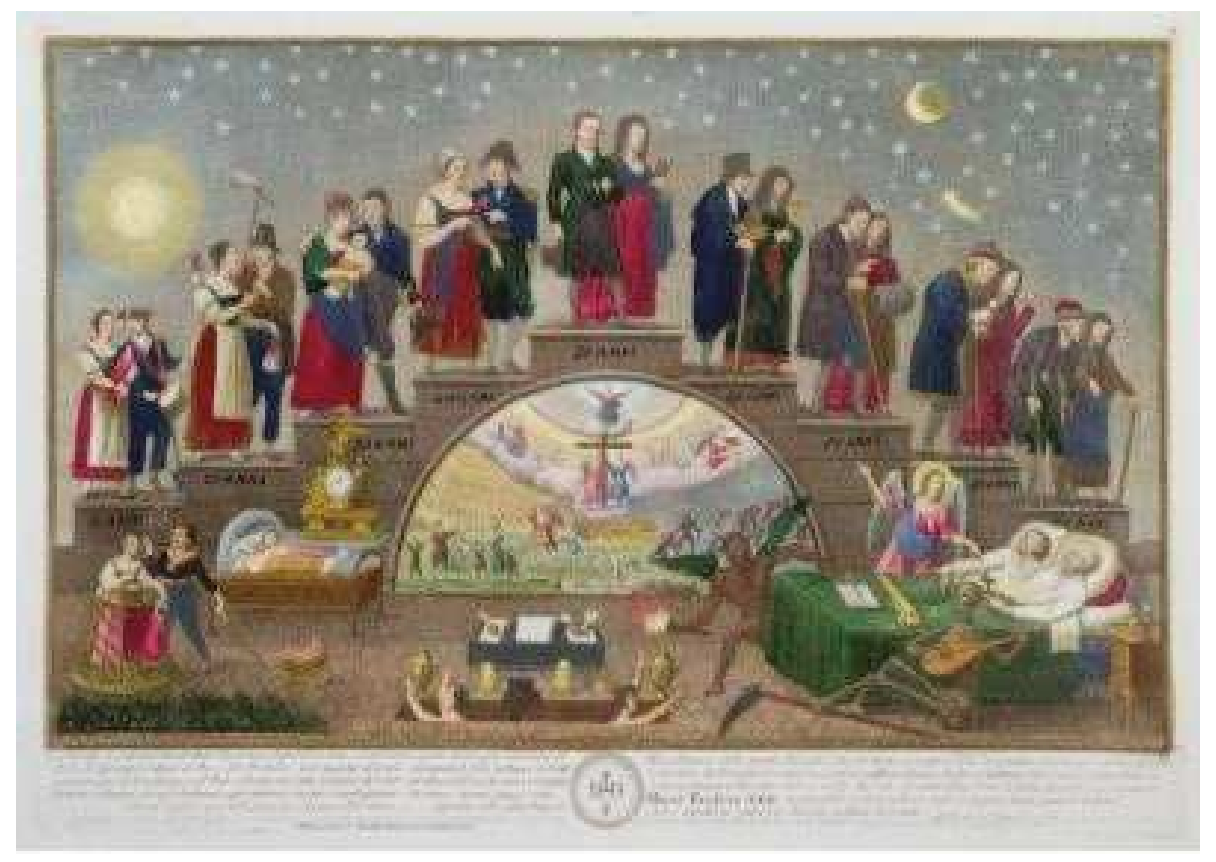

Figura 5: Representações de uma concepção naturalista da vida. A vida vista apenas como um ciclo que alimenta a linhagem, o corpo coletivo. Tela: A escada da vida humana ou As idades de vida, Gaetano Riboldi, $1790-1825.11$

Nas palavras de Gélis (1998, p. 317):

A fim de resolver da melhor maneira a contradição entre o desejo de viver e a vontade de perpetuar-se, os comportamentos familiares começaram a modificar-se. [...] No passado, os vínculos de dependência com relação à parentela eram vividos carnalmente; agora, eles se distendem: "meu corpo é meu" [...]. Esse arrancar simbólico do corpo individual ao grande corpo coletivo [...] permite compreender melhor por que a criança passa a ocupar um lugar tão importante entre as preocupações dos pais: é uma criança que ama por ela mesma e que constitui sua alegria de cada dia.

Gélis (1998) ressalta que estamos diante de uma mudança fundamentalmente cultural. Isso implica dizer que levou um tempo bastante considerável para sua efetivação. Além disso, como outras transformações culturais, isso não ocorreu de forma generalizada e concomitante em todos os lugares e camadas sociais. A preocupação de poupar as crianças dos males do mundo, característica do emergente sentimento moderno de infância, é um processo que logo se instaurou no seio das famílias burguesas concentradas nos grandes centros, porém que levou bastante tempo para atingir a alta nobreza e o povo que permaneciam movidos por padrões tradicionais.

11 Disponível em: <http://images.easyart.com/i/prints/rw/en_easyart/lg/3/0/The-Ages-of-Life-Italian-School305314.jpg>. Acesso em: 02 fev., 2008. 
Uma contribuição decisiva para o surgimento dessa concepção moderna de infância foi legada pelo francês Jean-Jacques Rousseau com o livro Emílio ou Da Educação. Nessa publicação, considerada um verdadeiro tratado da educação no mundo ocidental, esse filósofo suíço, profundamente influenciado por ideais iluministas, com base em suas experiências como mestre/preceptor e nas diferentes fases da vida, de forma romanceada, propôs uma forma de educar o Emílio (personagem fictício) desde o seu nascimento até os 25 anos de idade. Para ele (1995), desde o nascimento o homem começa a aprender, ele já está inserido em um processo de instrução, e isto antecede o desenvolvimento da fala e da audição.

Movido pela crença de que mesmo em uma sociedade corrupta o homem pode permanecer bom, sua condição natural, Rousseau responsabiliza a sociedade pela origem daquilo que é mau. Nela, então, cabia à educação desenvolver as potencialidades naturais da criança (ser boa) e seu afastamento dos males sociais inerentes. Fruto dessa concepção de indivíduo e sociedade, defendia que as necessidades individuais do desenvolvimento deveriam ser condutoras de toda a ação pedagógica infantil.

[...] o único hábito que devemos deixar que a criança pegue é o de não contrair nenhum. [...] Preparai à distância o reinado de sua liberdade e o uso de suas forças, deixando em seu corpo o hábito natural, colocando-a em condições de sempre ser senhora de si mesma e de fazer em todas as coisas a sua vontade, assim que a tiver. (ROUSSEAU 1995, p. 282).

Para muitos pesquisadores, a obra O Emílio ou Da Educação (publicada por volta de 1762) representa um testemunho de que outra concepção de infância estava se construindo naquele momento. Uma percepção da criança como um indivíduo que, como os adultos, também tinha as suas necessidades específicas. Uma prova disso é que nessa obra Rousseau manifesta sua grande preocupação com a educação inicial, e afirma, por exemplo, que nós adultos: "[...] nunca sabemos colocar-nos no lugar das crianças; não penetramos suas ideias, mas lhes emprestamos as nossas, seguindo sempre os nossos raciocínios. Junto com as cadeias de verdades acumulamos em suas cabeças apenas extravagâncias e erros." (1995, p. 210).

A infância, para esse autor, era uma fase que tinha seu caráter e suas especificidades. Foi um dos primeiros pensadores a dar o devido valor à condição infantil. $\mathrm{Na}$ sua concepção, o ser humano, ao nascer, depende essencialmente do adulto, pois nasce desprovido de tudo, com necessidade de assistência: "[...] nascemos estúpidos, precisamos de juízo. Tudo o que não temos ao nascer, e de que precisamos adultos, é nos 
dado pela educação. Essa educação nos vem da natureza ou dos homens ou das coisas." (ROUSSEAU, 1995, p. 10).

A emergência dessa nova forma de conceber a infância e a consequente necessidade de outra maneira de educar culminou com a paulatina retirada das famílias do espaço público-social (como ocorria na Idade Média) e estabeleceu limites entre o mundo infantil e o mundo dos adultos. Também resultou no enclausuramento da infância, seja nas casas de suas famílias (espaço do privado), seja nos espaços criados para recebê-las, a exemplo das escolas e internatos.

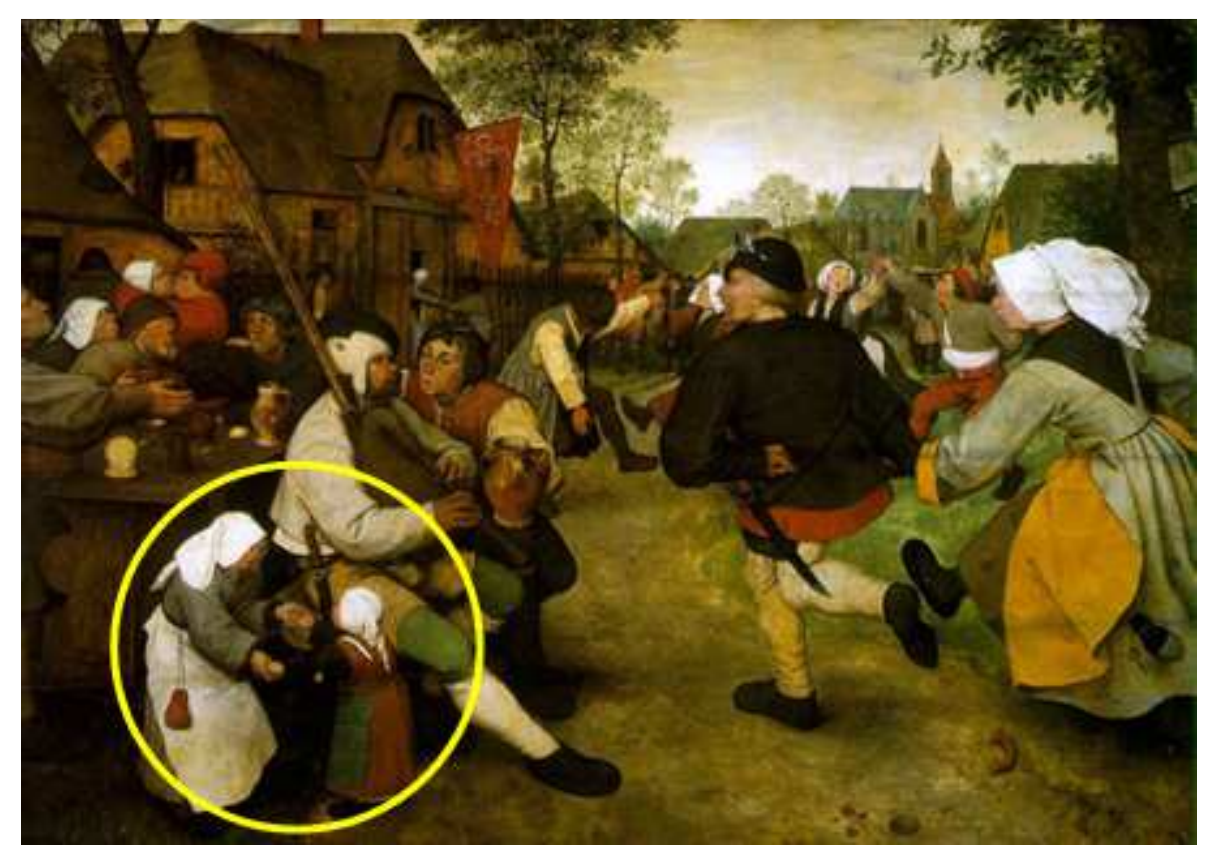

Figura 6: As dimensões do público e do privado. Crianças e adultos convivendo lado a lado em espaços abertos da sociedade flamenga (medieval), observada e representada por Pieter Bruegel, O Velho: Tela: Dança camponesa. ${ }^{12}$

12 Disponível em: <http://bruegelmortosdefama.blogspot.com/2008/08/dana-camponesa-1566-1567banquete.html>. Acesso em: 02 fev., 2008. 


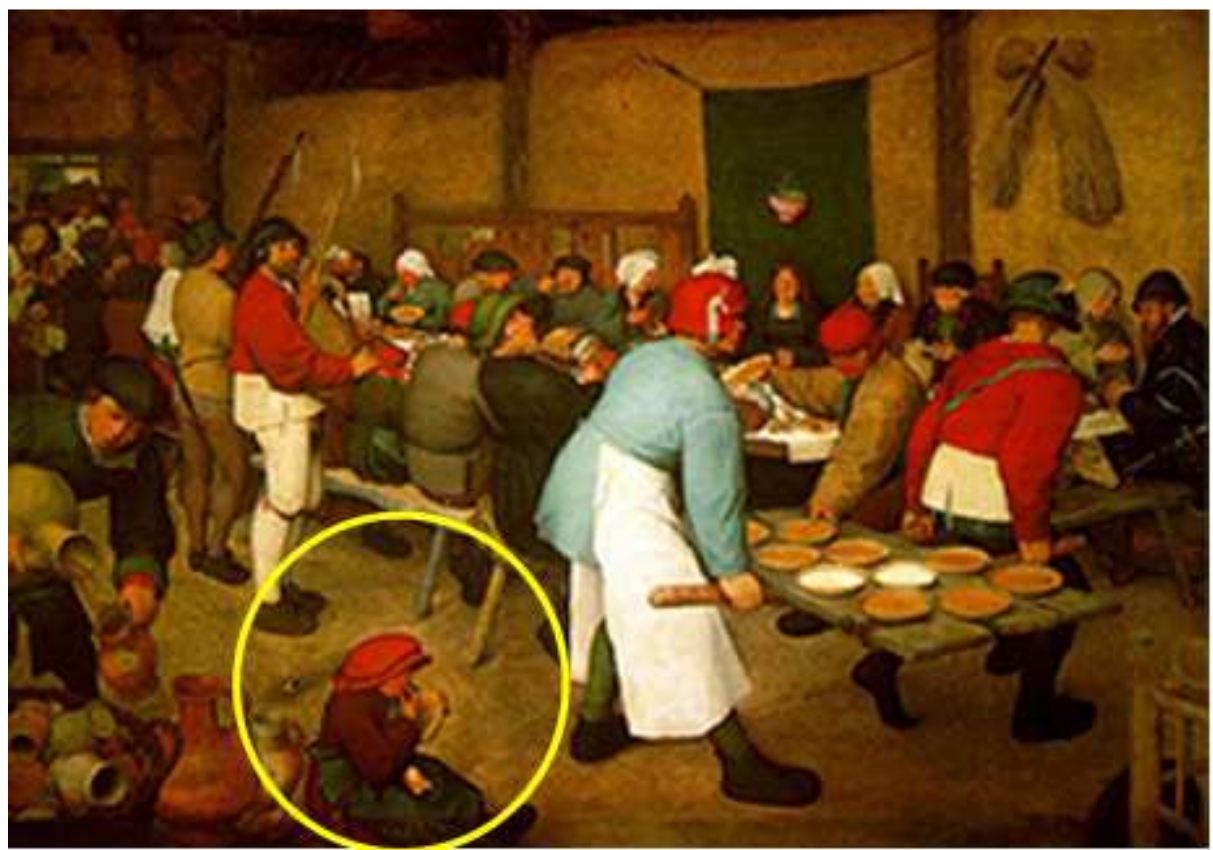

Figura 7: Já em espaços fechados da sociedade flamenga (medieval), ainda encontramos a presença infantil junto aos adultos. Pieter Bruegel, O Velho, Tela: Festa de casamento. ${ }^{13}$

Contrapondo-se ao universo medieval, quando crianças e adultos ocupavam em conjunto o espaço público, onde realizavam seus trabalhos, jogos, festas, brincadeiras etc., na modernidade, este espaço irá tolerar cada vez menos a presença de crianças nos domínios agora estatais. Dessa maneira, esses lugares são de permanência e trânsito dos adultos, diferente dos observados na Idade Média. Afinal, agora existiam as restrições estabelecidas pelo Estado Moderno que, movido por interesses capitalistas, logo cuidou de execrar o modelo de organização legado até então pela tradição e tornou hegemônicas formas de organização social que atendiam prioritariamente às necessidades de ordem capitalista. Consequentemente, a criança foi confinada dentro de casa, vez por outra, nos quintais e jardins cercados, já que os espaços públicos passaram a ser limitados ao uso dos adultos, sob o controle e a supervisão do Estado.

\footnotetext{
13 Disponível em: <http://ruvasa2a.blogspot.com/2008/07/1584-festa-de-casamento-bruegel-o-velho.html>.
} Acesso em: 02 fev., 2008. 


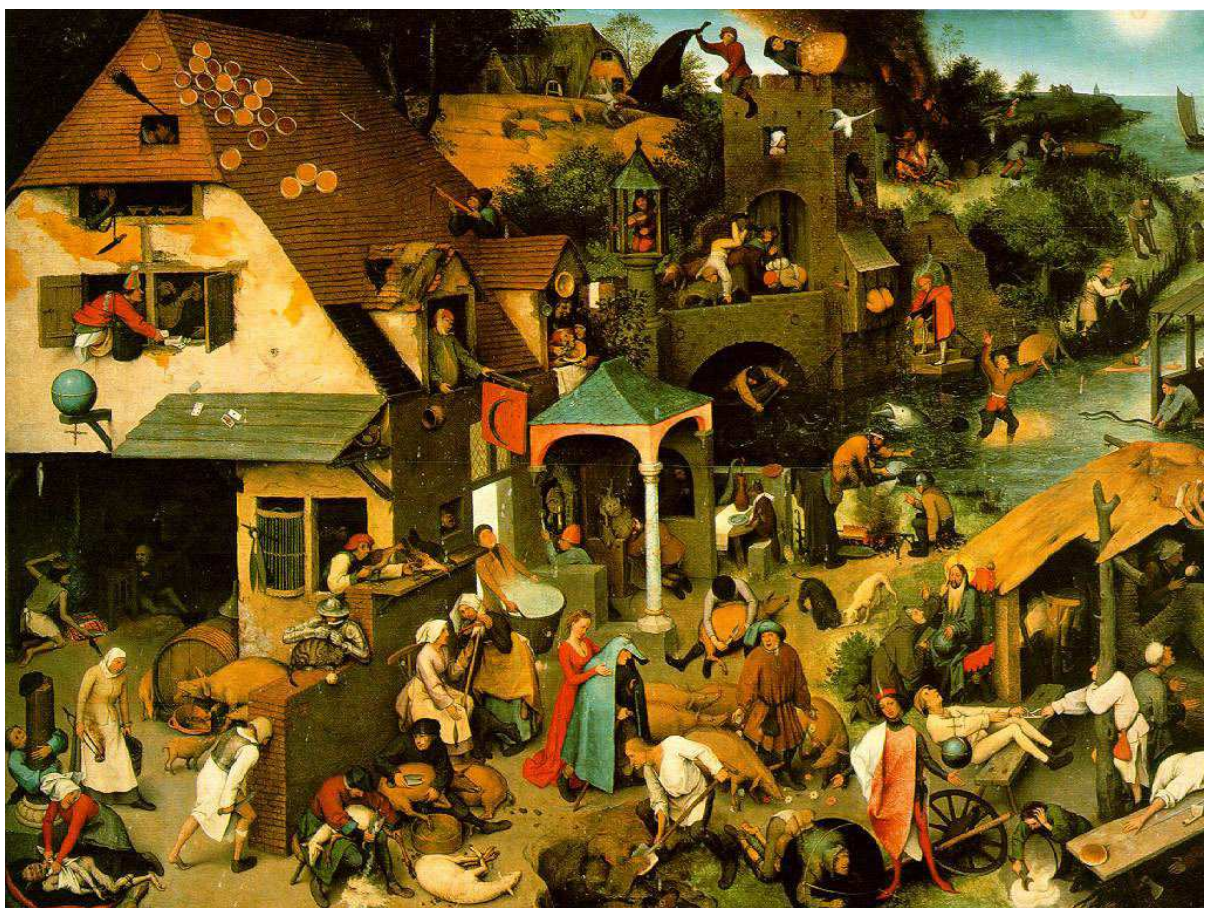

Figura 8: Permanência das pessoas nas ruas na Idade Média. A confusa relação entre o espaço público e o privado, característica daquele momento histórico, quando estas categorias não estavam bem definidas ainda. Tela: Os provérbios de Netherlandish ou o casaco azul, 1559, Pieter Bruegel, O Velho. ${ }^{14}$

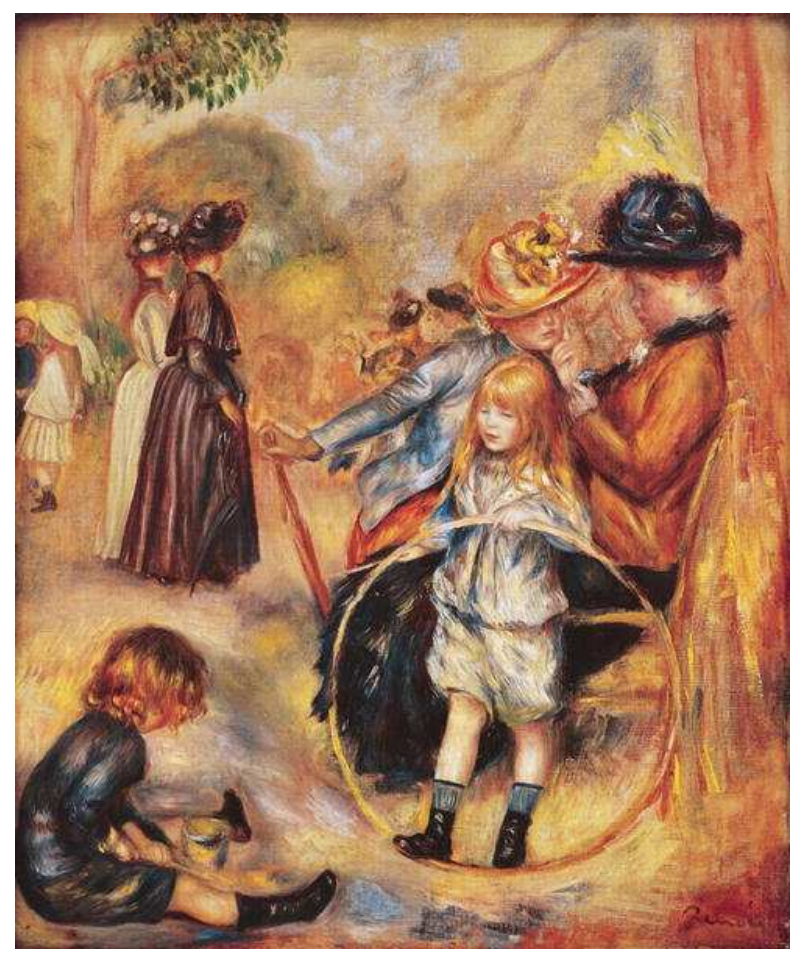

Figura 9: Tela: Nos jardins de Luxemburgo, Pierre Auguste Renoir, 1883. ${ }^{15}$

\footnotetext{
${ }^{14}$ Disponível em: < http://4.bp.blogspot.com/_vYCtUIcGHXI/R0fe9Jkiu1I/AAAAAAAAAuo/oJ_3C-1LgQ/s1600-h/proverbs.jpg>. Acesso em: 02 fev., 2008.

15 Disponível em: < http://dotempodaoutrasenhora.blogspot.com/2010_12_26_archive.html>. Acesso em: 02 fev., 2008.
} 


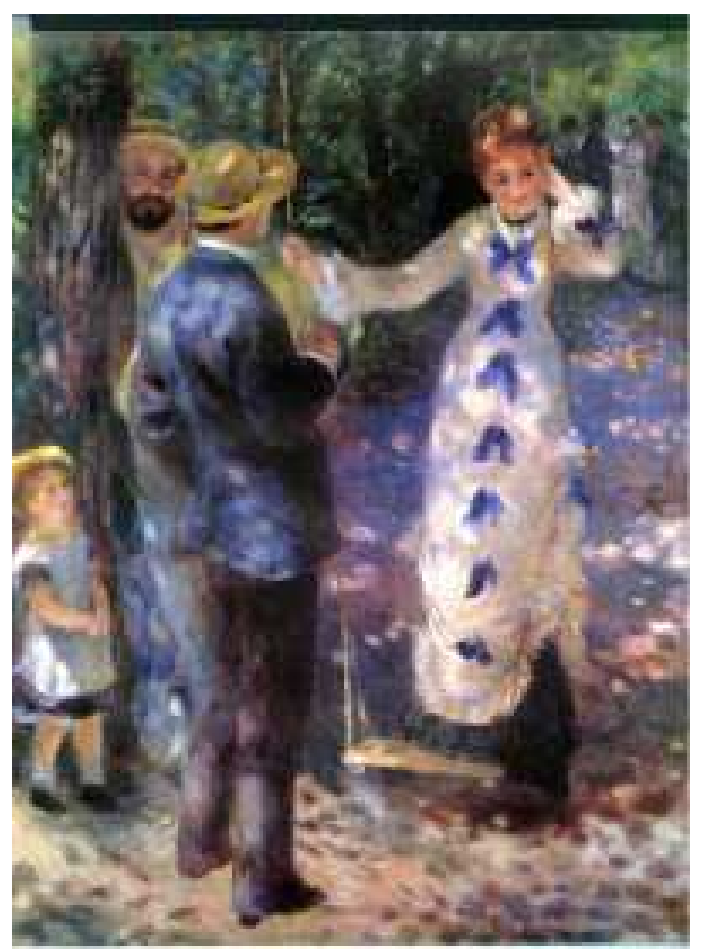

Figura 10: Tela: O balanço, Pierre Auguste Renoir, 1876. - O espaço público tolera cada vez menos a presença das crianças. Quando isso ocorre, essas geralmente estão sob a vigilância (controle) dos adultos. Na tela "O balanço", até mesmo os espaços, legítimos deles, são invadidos pelos adultos. ${ }^{16}$

A sociedade organizada dessa forma passa cada vez mais a viver sob a égide de um Estado capitalista forte que, definitivamente, começa a exercer controle tanto sobre a vida pública quanto sobre vida privada. Sarmento (2005) chama a atenção para o fato de que é a separação do mundo dos adultos e a institucionalização das crianças que vão sustentar a construção moderna da infância. Mais adiante, atesta que as escolas e creches foram as primeiras instituições criadas pelo Estado moderno para atender a esse outro grupo geracional. (crianças).

A separação das crianças do mundo dos adultos somada aos direitos a elas legados foram fundamentais para que elas não sofressem tanto a perversidade do trabalho nas fábricas com a Revolução Industrial desencadeada na segunda metade do século XVIII. Na eminência de tornarem-se trabalhadoras junto com suas mães, esses dois fatores deram condições legais para que a sociedade reagisse contra o trabalho infantil que os países industrializados perspectivavam explorar.

Também em consequência dessas transformações, a educação das crianças, que na Idade Média era feita pela família-tronco, em espaços abertos, públicos, o que acabava confundindo trabalho com educação, que também constituía uma forma de inserção na

16 Disponível em: <http://www.revistamoviola.com/2007/09/27/o-balanco/>. Acesso em: 07 abr., 2008. 
coletividade e perpetuação da linhagem, agora estaria especialmente a cargo das escolas, a maioria eclesiásticas e públicas que, além de integrar as crianças à comunidade e aos seus valores legitimados pela Igreja e pelo Estado, deveriam, considerando a concepção natural de infância, cuidar para que as crianças avançassem no seu processo de assimilação das normas e aplicar penalidades, por vezes, severas, àquelas que se recusassem a assimilalas. (MIRANDA, 1986). Com isso, buscava-se desenvolver nelas aptidões para assumirem sua função na engrenagem criada pelo Estado capitalista burguês.

Em vista disso, o Estado não encontrou muita dificuldade para assumir esse papel de direito de atuar como protetor das crianças. Registre-se que da mesma forma como havia ocorrido com a revolução da imprensa, que foi responsável sobremaneira pela consolidação do modelo moderno de infância burguês, ao possibilitar a propagação dos livros, condição indispensável à escolarização; no contexto da Revolução Industrial, muitas famílias agora eram convidadas a explorar a mão de obra de seus filhos, em nome do desenvolvimento e do orçamento familiar, ocasião propícia para a atuação do controle estatal sobre a instituição familiar.

\begin{abstract}
Nesse contexto de estrangulamento do político, de redução crescente do espaço público e da sua transformação em espaço social privado, governado por proprietários [...], ocorrerão mudanças fundamentais nas formas de conceber e organizar a infância. Como não poderia deixar de ser, a privatização das relações sociais alcança a cidadania infantil, fazendo também que as crianças e jovens se distanciem cada vez mais do que resta de vida pública, à medida que a ordem burguesa vai-se constituindo. Com a burguesia, pouco a pouco e à medida que a urbanização evolui, a infância passa a viver confinada nos espaços propriamente privados - os espaços domésticos - ou nesses híbridos, ao mesmo tempo sociais e privados - os espaços confinados especializados (escolas, internatos, creches e outros). (PERROTTI, 1990, p. 88).
\end{abstract}

A modernidade alargou a distância entre adultos e crianças, não apenas pela construção da infância como uma fase de dependência, mas também pela construção de uma imagem do adulto como um ser independente, dotado de maturidade psicológica, direitos e deveres de cidadania. (ELIAS apud DEBERT, 1998).

Frente a tais considerações, podemos inferir que a infância que conhecemos hoje se constitui como um fenômeno inerente à sociedade moderna e veio edificando-se ao longo desse tempo. Pode-se dizer que foi no século XIII que teve início a construção de uma concepção de infância que reconhecia a criança em sua especificidade; por volta do século XVIII, já era comum um olhar que compreendia crianças e adultos como indivíduos com necessidades diferenciadas; porém, foi somente em meados do século XIX, mais especificamente nos anos de 1850, que o conceito burguês de infância atingiu seu apogeu, 
o seu auge, pois a partir deste momento são legítimas e legitimadas as roupas, as brincadeiras, a linguagem e até uma psicologia inerente e característica ao mundo infantil.

Isso nos leva a entender a infância como uma construção social, histórica e cultural que se manifesta ao longo da história da humanidade por meio de trajes, de jogos e brincadeiras, da literatura, da educação e suas instituições, da arte, das relações familiares. Essa nova mentalidade da sociedade moderna fez com que surgisse outro conceito de infância em que a criança se diferenciava do adulto e passava a ser considerada portadora de características específicas. A partir desse momento, essa sociedade veio, incessantemente, definindo e distinguindo o "mundo da criança" do "mundo do adulto". De acordo com Cohn (2005), trata-se de uma ruptura que se estabelece entre essas duas experiências sociais: adulta e infantil, fomentada, sobretudo, pelo reconhecimento da particularidade da infância em relação ao mundo dos adultos.

Com a emergência da idade moderna, como ensina Hanna Arendt (1991), também se edifica um híbrido caracterizado essencialmente pela preponderância dos interesses privados sobre aquilo que é público. Tendo assumido essa configuração, como estratégia de controle e manipulação, a infância nos séculos seguintes será profundamente marcada pelo ideal positivista que insistirá na proposição de que ela deve ser vista de forma naturalizada, uma etapa para a vida adulta, em que a criança é concebida como um ser incompleto que carece do controle do adulto.

Veiga (2004) reforça essa indicação ao afirmar que:

[...] as relações entre infância e modernidade se estabeleceram no esforço de produção de uma tradição, o ser criança civilizada. Compreendendo o tempo da infância como produção sociocultural, entendo que a possibilidade do aparecimento de um tratamento distinto da criança em relação ao mundo adulto esteve associada à produção de lugares específicos a ela destinados, à produção de novas relações de autoridade e à elaboração de novas formas de comportamento. Esses elementos foram fundamentais para que o ser criança civilizada fosse universalizado como infância na modernidade, revelando-se como uma tradição. (p. 37).

Entre as críticas que podem ser feitas ao modelo de infância moderna burguesa que legamos, Oliveira (1989) denuncia que a especificidade da criança se fez por meio de uma ideologia orgânica e hegemônica da sociedade burguesa. Assim, esse outro conceito de infância faz parte de um processo ideológico de camuflagem, pois expressa uma igualdade abstrata entre as pessoas (crianças). Desconsideram-se as diferenças sociais, econômicas, políticas e culturais que se apresentam numa sociedade em que apenas uma classe social exerce um poder hegemônico e controlador a respeito das demais: "[...] no bojo dessa 
ideologia que a sociedade burguesa construiu e realizou essencialmente para as crianças das classes dominantes, desde o seu nascedouro, uma concepção de vida infantil se construiu e se fez aceita." (p. 118).

\subsection{A Infância na contemporaneidade: Infâncias e Culturas da Infância}

A infância, como qualquer outra etapa da vida, adquire em parte sua especificidade graças às experiências singulares que se tem nos diferentes contextos em que se vive e se participa durante essa etapa. As condições da infância são definidas por esses nichos, a singular interação entre eles e a particular forma de vida que possibilitam para cada sujeito ou grupos de sujeitos (crianças, de classe baixa ou classe alta, de contextos desenvolvidos ou subdesenvolvidos, que vivem em meios rurais ou urbanos, em diferentes culturas, etc.). Em sentido estrito, não existe infância no sentido abstrato, pois cada individuo vive a sua de forma particular. (SACRJSTÁN, 2005, p. 34).

$\mathrm{Na}$ concepção de Cohn (2005), o que hoje entendemos por infância no mundo ocidental foi sendo elaborado ao longo do tempo na Europa, simultaneamente com mudanças na composição familiar, nas noções de maternidade e paternidade, e no cotidiano e na vida das crianças, inclusive por sua institucionalização pela educação escolar. Adverte ainda que não podemos tomar a ideia de infância como naturalizada, universal como quer o Estado e a sociedade burguesa, pois em outras culturas e sociedades, a ideia de infância pode não existir, ou ser formulada de outras maneiras.

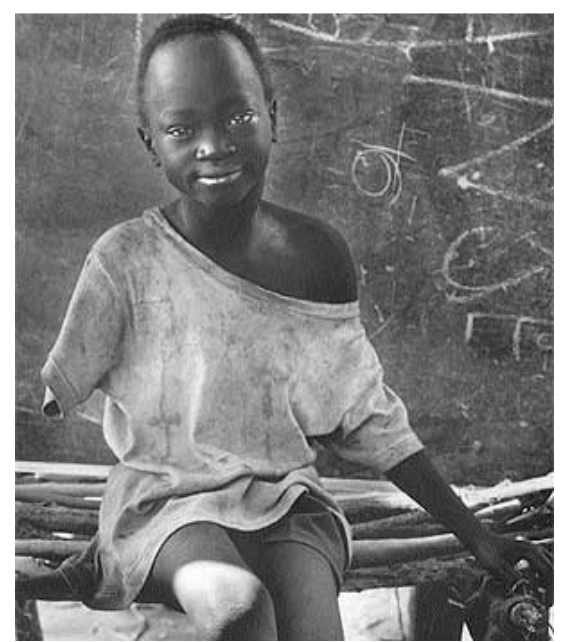

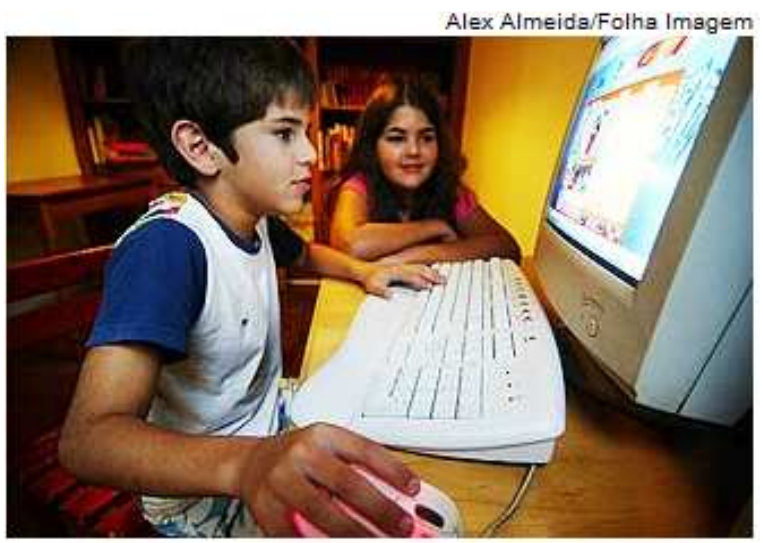

Figura 12: Foto de duas crianças brasileiras que ilustraram uma reportagem do Jornal Folha de São Paulo (30/08/2008) intitulada: Crianças brasileiras ficam 
Figura 11: Menino mutilado no campo para refugiados ruandeses, Zaire (atual Congo), Exposição Crianças da Guerra de Sebastião Salgado. Tela: O Biaro, $1997 .{ }^{17}$

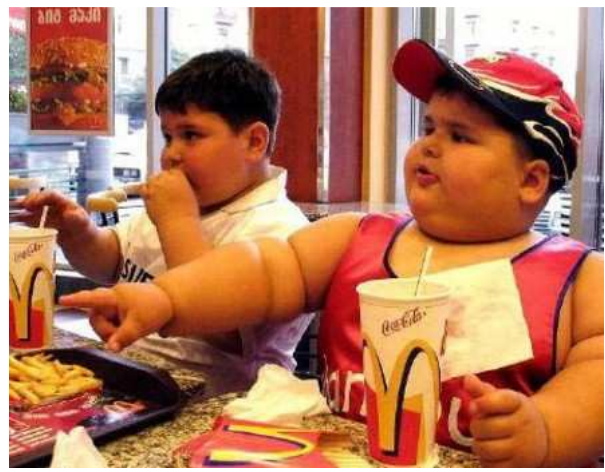

Figura 13: O consumo infantil. Crianças americanas em loja da Rede McDonald's. ${ }^{19}$

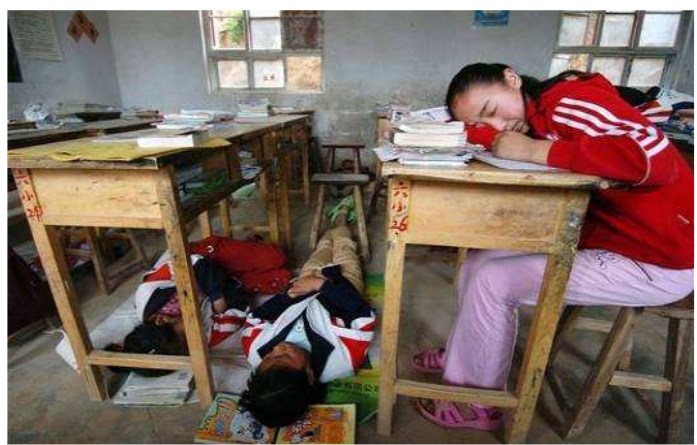

Figura 15: Foto ilustrativa da reportagem: Adolescentes chineses dormem em sala de aula de escola na zona rural de Ruicheng, no norte do país. O texto reporta a criação da lei (01.06.07) que assegura às crianças chinesas o direito de dormir e brincar. Devido à enorme pressão escolar, dormir e brincar até então eram privilégios para poucas das 300 milhões de crianças do país. ${ }^{21}$ mais de $19 \mathrm{~h}$ na Internet por mês. ${ }^{18}$

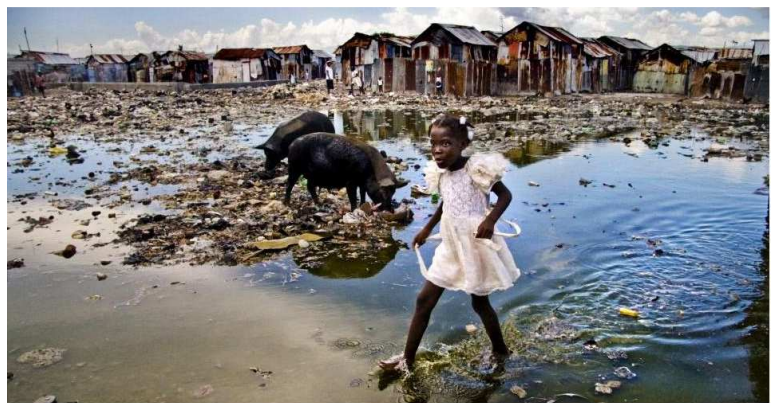

Figura 14: As muitas infâncias presentes na sociedade contemporânea. Menina no subúrbio de Porto Príncipe, fotografia de Alice Smeets, Haiti, 2007. Foto ganhadora do prêmio foto do ano promovido pela UNICEF. 20

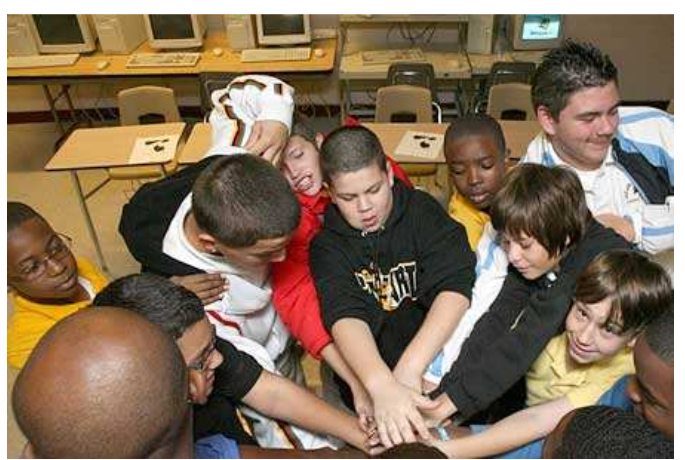

Figura 16: Crianças inglesas que participaram de um estudo da Universidade de Warwick, que mostrou que os alunos europeus de classe baixa têm piores expectativas e desempenho na escola que os seus colegas africanos ou asiáticos nas mesmas condições. ${ }^{22}$

Para Sarmento (2006, p. 17), trata-se de um fato consumado, o lugar da infância na contemporaneidade é um lugar em mudança. A modernidade estabeleceu uma norma da infância, em larga medida definida pela negatividade constituinte:

[...] a criança não trabalha, não tem acesso direto ao mercado, não se casa, não vota nem é eleita, não toma decisões relevantes, não é punível por crimes (é inimputável). Essa norma assenta num conjunto estruturado de

\footnotetext{
17 Disponível em: <http://www.unicef.org/salgado/>. Acesso em: 12/08/08.

18 Disponível em: <http://www1.folha.uol.com.br/folha/informatica/ult124u439545.shtml.> Acesso em: 12/08/08.

${ }^{19}$ Disponível em: <http://comus1.wordpress.com/2007/08/10/mcdonalds-e-consumo-infantil/> Acesso em: 05/01/08.

20 Disponível em: <http://www.alicesmeets.com/images/intro.jpg>. Acesso em: 07/01/09.

21 Disponível em: <http://g1.globo.com/Noticias/Mundo/0,,MUL45512-5602,00.html>. Acesso em: 03/02/09.

22 Disponível em: <http://www.sptimes.com/2007/11/22/images/tb_StewartBoys_450x300.jpg>. Acesso em: 03/02/09.
} 
instituições, regras e prescrições que se encarregam da "educação" da criança, especialmente a escola e a família.

Essas considerações que marcam nosso tempo são decisivas para Debert (1998) inferir que essa definição ideológica burguesa de infância contribui para o surgimento do que a autora entende como um processo de institucionalização do curso da vida. Para ela: "A padronização da infância, adolescência, idade adulta e velhice pode ser entendida como resposta às mudanças estruturais na economia, devido, sobretudo à transição de uma economia que tinha como base a unidade doméstica, para uma baseada em um mercado de trabalho". (p. 18-19).

Nessa perspectiva apontada por Debert (1998), o conceito de infância está suscetível às estruturas de poder que o manipulam, sendo a principal delas o Estado Moderno. Isso justifica a indicação de Steinberg e Kincheloe (2004) quando afirmam que a infância está sujeita a mudar de tempo em tempos em virtude das transformações sociais mais amplas que se manifestam no dia a dia.

Conforme as considerações de Arendt (1991), a manutenção dessa condição está garantida pela própria organização social a qual estamos submetidos. Em sua perspectiva, os homens são seres condicionados, até mesmo aqueles que condicionam o comportamento de outros se tornam condicionados pelo próprio movimento de condicionar. Uma das maneiras como isso ocorre é dada pelo contexto histórico em que vivemos, a cultura, os amigos, a família.

Em tempos configurados dessa forma, o ideal de infância e o tipo de arranjo familiar burgueses colaboram decisivamente para a manutenção do controle exercido pelo Estado sobre a sociedade, pois a concepção de infância moderna burguesa é construída a partir da relação que se estabelece entre a criança, o adulto e essa sociedade. O que acaba prevalecendo é o que todos esperam da criança, uma vez que a sociedade é organizada e condicionada primeiramente pelo adulto.

Sendo assim, quando falamos da concepção de infância no mundo contemporâneo, mesmo considerando o caráter ativo e dinâmico na relação da criança com o adulto, não podemos negar que o adulto exerce um poder significativo sobre ela na nossa sociedade. Em seus estudos a respeito das periodizações e fontes da História da Infância, Gouvêa (2008, p. 111) faz as seguintes considerações:

Mesmo sendo um sujeito ativo no processo de socialização, a criança tem uma peculiaridade advinda de seu lugar no mundo social. Nas interações com os adultos, mediadas por produtos culturais a ela dirigidos, a criança recebe, significa, introjeta e reproduz valores e normas, ou hábitos, tidos 
como expressões da verdade. A criança é depositária e destinatária dos discursos e práticas produzidos sobre a infância. Não existe um sujeito criança anterior ou externo a tal produção.

Isso leva-nos a deduzir que a concepção de infância burguesa é eminentemente produzida pelo e para o adulto e, ainda que a criança recuse ou conteste esta concepção, é ele quem irá definir os contornos e as nuances válidas de infância. Nessa relação, o adulto reproduz na sua relação com a criança a mesma estrutura dominante de autoridade que é exercida na sociedade.

Cada um de nós tem ideias a respeito dos menores baseadas em disposições e atitudes para vê-los e abordá-los de uma forma determinada que, sem dúvida, estão ligadas à experiência própria de termos sido crianças, por semelhança ou oposição ao que cada um foi. Dispomos de modelos culturais definidos [...] Aprendemos coletivamente a ser de uma forma determinada com as crianças, a cuidar, a disciplinar, a amar, a vê-los voltados para o futuro. (SACRISTÁN, 2005, p. 26). (grifo nosso).

Como outras instituições reguladoras da infância, a família é uma unidade de muito interesse para o Estado e para a sociedade burguesa, pois é no seio desta que a manutenção da opressão exercida por estas duas organizações (Estado e sociedade) se efetiva sobre ela.

Faz-se importante ressaltar, também, que não podemos condenar as famílias por esse ato, pois, como adverte Charlot (1986), o adulto não considera a autoridade que exerce sobre a criança como um ato social. Assim, por vezes, acaba definindo e concebendo a criança apenas a partir de sua natureza infantil, ou seja, cria e faz a manutenção de um conceito abstrato e universal de criança, sem considerar as desigualdades vivenciadas e a classe social a qual essa pertence.

Conforme Sacristán (2005, p. 26), são essas visões de infância partilhadas pelos adultos que vão determinar: "[...] a importância que damos a elas (crianças), o comportamento que temos com elas, os sentimentos que desenvolvemos em relação a elas, as atitudes pedagógicas com as quais trabalhamos para seu bem-estar, assim como o que consideramos que 'falta' e 'sobra' para elas." Para esse autor, as concepções do adulto a respeito da criança resultam de um conjunto de imagens que foram sendo construídas ao longo de sua formação social. Essa formação resultará em uma representação social do infantil.

Também com base nos estudos de Sacristán (2005), podemos observar que ao longo da história as concepções de infância são marcadas por duas condições: a primeira se refere à condição da criança como ser influenciável; já a segunda, é a crença de que as 
marcas que nela se imprimem perdurarão ao longo de suas vidas. Isso justifica o que afirma o autor quando diz que "[...] a humanidade esteve de acordo que os menores podem ser orientados, conduzidos, levados e corrigidos e foi coerente com essa ideia ao desenvolver as práticas correspondentes de guiar, impor e de educá-los." (p. 27).

Para Cohn (2005), um aspecto que merece atenção é que as crianças não são apenas produzidas pelas culturas, mas são também produtoras de culturas. E, ao que parece, isso não foi levado em conta quando elas tiveram seu mundo separado do dos adultos; simplesmente passaram a ser consideradas totalmente dependentes, tendo negado assim qualquer autonomia em relação ao adulto. Isso contribui para a imposição da cultura do outro - adulto dominante - e a perpetuação dessa dinâmica.

Ao alertar que as crianças também são produtoras de cultura, Cohn (2005) prenuncia a gênese de outra concepção de infância que tende a coexistir e talvez com o tempo, suplantar aquela herdada do ideário burguês. É cada vez mais recorrente os pesquisadores que se ocupam em investigar a infância levantarem suspeitas de que as mudanças pelas quais a sociedade veio passando da modernidade até a contemporaneidade desencadearam uma lenta, mas perceptível reconfiguração da ideia de infância, pois é claramente verificável que as características das infâncias vivenciadas hoje são outras bem diversas das que foram experienciadas há algum tempo atrás.

Alguns autores mais extremistas, como Postman (1999), por exemplo, até profetizaram o desaparecimento da infância. A partir de seus estudos, esse autor afirma que o fato de a família vir gradualmente perdendo o controle sobre a vida de seus filhos, sobretudo devido à crescente força que as mídias vêm ganhando na sociedade desde o surgimento da prensa de Gutenberg, contribui diretamente para o desaparecimento da linha divisória entre a infância e a vida adulta. $O$ que parece constituir um retorno ao que se observava na baixa Idade Média, quando as crianças também tinham acesso aos segredos dos adultos. Para ele, em um mundo letrado, ser adulto implica ter acesso a segredos culturais codificados em símbolos não naturais. E nesse mundo, as crianças acabam se transformando em adultos por também terem acesso a esses segredos, especialmente quando eles são alardeados pela telinha da tevê.

Considerando o estágio atual da sociedade contemporânea, que tem seu cotidiano definitivamente marcado pela ação da Indústria Cultural, efetivada pela ação das mídias, especialmente a televisão, Postman (1999) considera:

A televisão destrói a linha divisória entre infância e idade adulta de três maneiras, todas relacionadas à sua acessibilidade indiferenciada: primeiro, porque não requer treinamento para apreender sua forma; segundo porque 
não faz exigências complexas nem à mente nem ao comportamento, e terceiro porque não segrega seu público. (p. 94).

Apesar de concordar com esse autor de que existem implicações severas da ação da Indústria Cultural nos contornos e nuances dessa nova concepção de infância que emerge na contemporaneidade, consideramos que a teoria dele tende a simplificar um contexto que, ao que entendemos, constitui-se muito mais complexo.

Nosso entendimento fundamenta-se em estudos ainda recentes, oriundos de áreas do conhecimento como a psicologia social, a antropologia da educação e a sociologia da infância. Estudos produzidos nessas áreas têm reivindicado, de maneira bastante incisiva, a desconstrução do paradigma tradicional da infância, a ótica que a vê apenas como uma fase natural, abstrata e universal na vida do ser humano, o que relega as crianças à condição de entidades biológicas, meros objetos que os adultos podem manipular e socializar de acordo com sua ordem social, sua cultura de adultos.

Ressalte-se aqui que não negamos a importância dos aspectos biológicos na constituição das infâncias experienciadas no mundo contemporâneo. Porém, também não se pode contestar que "[...] o desenvolvimento biológico não corresponde a toda a realidade da criança. Mesmo porque o aspecto biológico sofre as determinações da condição social do indivíduo." (MIRANDA, 1986, p. 128). Pode-se depreender, então, que mesmo tendo sua constituição determinada em parte pelos aspectos biológicos, é na condição social que o homem se faz homem; que a mulher se faz mulher; que o velho se faz velho; que o adolescente se faz adolescente; e que a criança se faz criança.

Ao longo de grande parte da história da humanidade às crianças foi negado um estatuto social e uma autonomia existencial, o que as relegou à condição de simples seres biológicos, incompletos, incapazes de participação social, não detentores de práticas culturais próprias, autênticas (SARMENTO, 2004). Partindo disso, faz-se urgente e necessário que seja resgatada a condição de sujeito social ativo da criança, pois, conforme as palavras do professor William Corsaro (1997): "[...] as crianças são agentes ativos, que constroem suas próprias culturas e contribuem para a produção do mundo adulto." (p. 05).

Tem sido cada vez mais recorrente na sociedade contemporânea a produção de estudos e pesquisas que apontam essa ruptura com o processo de manutenção que perpetuava os lugares, os papéis e os saberes a respeito da universalização da infância legados e inerentes à modernidade.

No enfrentamento dessa realidade, pesquisadores, especialmente do campo da Sociologia da Infância, nos convidam a considerar as crianças como atores sociais plenos que, conforme lembra Corsaro (1997) não se limitam a apenas adaptar e internalizar os 
processos de socialização da cultura dos adultos. Na condição de atores sociais, também são capazes de construir seus processos de apropriação, reinvenção e reprodução.

\begin{abstract}
Esta noção de socialização na sociologia da infância estimula a compreensão das crianças como atores capazes de criar e modificar culturas, embora inseridas no mundo do adulto. Se as crianças interagem no mundo adulto porque negociam, compartilham e criam culturas, necessitamos pensar em metodologias que realmente tenham como foco suas vozes, olhares, experiências e pontos de vista. (DELGADO e MÜLLER, 2005, p. 353).
\end{abstract}

Essa forma de conceber a infância e as crianças implica em compreendê-las em contextos específicos, com experiências específicas e em situações da vida real (DELGADO e MÜLLER, 2005). Isso está plenamente justificado em virtude de a Sociologia da Infância entender a infância não apenas como uma fase biopsicológica, mas "[...] como uma categoria social do tipo geracional ${ }^{23}$ por meio da qual se revelam as possibilidades e os constrangimentos da estrutura social." (SARMENTO, 2005, p. 363).

Dentre os inúmeros fatores que contribuíram para que a infância passasse a ser considerada uma categoria social relevante, ao ponto de a Sociologia ter dedicado a ela uma vertente no sentido de desenvolver estudos para compreendê-la, podem ser elencados: "[...] as transformações relativas à família, à situação social da mulher, e ao estatuto da criança e do adolescente ocorridas no bojo das mudanças socioeconômicas das sociedades contemporâneas." (BELLONI, 2007, p. 63).

Retomando nosso diálogo com Postman (1999), consideramos mais sensato dizer que talvez estejamos mesmo presenciando um desaparecimento da infância, todavia não dessa como categoria, mas sim de um modelo de infância, da infância burguesa. Afinal, ao considerarmos a criança como um ator social, um agente ativo produtor de cultura, já não podemos considerar a existência de uma infância, mas a existência de muitas infâncias. Daí sim nos parece adequado afirmar que está desaparecendo uma infância, aquela que surgiu no início da idade moderna, que foi gestada e legada pela burguesia.

Nesse aspecto, tem todo sentido o que afirma Sarmento (2005) quando diz que: "a história da infância não se extingue com a modernidade tardia, nem as contradições sociais contemporâneas se estabelecem como horizonte temporal da "morte da infância" - como pretende Postman (1999) - "[...] pelo contrário, as encruzilhadas da infância contemporânea

\footnotetext{
23 Por categoria geracional, pode-se depreender dos estudos de Sarmento (2005) que se trata de uma categoria que muda a cada geração, ou seja, com o tempo, com o decorrer da história. É razoável entender, por exemplo, que os professores e alunos enfrentam conflitos geracionais em relação às infâncias vivenciadas.
} 
não fazem senão realçar a sua diferença como categoria geracional distinta, nos planos estrutural e simbólico." (p. 370).

Ao conceberem a infância como uma categoria etária, geracional e plural, os pesquisadores da Sociologia da Infância alertam para a complexidade que a abordagem desta categoria exige. Para eles, deve-se execrar definitivamente o entendimento da infância em uma perspectiva naturalista que nega à criança o seu estatuto social, relegandoa à condição de ser abstrato universal, abarcável exclusivamente por "fases de desenvolvimento", também universais.

Apesar do avanço dos estudos nessa perspectiva, ainda hoje nos deparamos com tratamentos dessa natureza, a qual em muitos se perpetua enquanto uma verdade canônica, imutável. "Em certos textos, essas etapas adquirem uma coloração normativa, pouco importando com a variedade dos contextos efetivos nos quais indivíduos concretos são chamados a se desenvolver." (JAVEAU, 2005, p. 382).

A crítica a essa compreensão da criança como objeto abstrato e à ideia que restringe a compreensão da infância à identificação da fase do desenvolvimento a qual a criança se encontra também tem ressonância na obra de Steinberg e Kincheloe (2004). Para essas autoras, o equívoco de se conceber a infância a partir de uma perspectiva dessa natureza, como uma espécie de herança do nascimento, encontrou solo fértil nos anos de $1900 \mathrm{com}$ a edificação de uma psicologia comportamental infantil moderna, tomada pelos saberes que circulavam naquele período.

Esse fato trouxe sérias consequências para o entendimento da infância, pois interpretações superficiais e usos pouco adequados dos saberes dessa área passaram a ser seguidos como dogmas. Um exemplo desse processo de tentativa de naturalização da infância foi o que ocorreu com a obra de Jean Piaget no início do século XX. Naquele momento, seus estudos a respeito da constituição genética da conduta infantil, inadvertidamente, passaram a ser generalizados para qualquer realidade, muitas vezes desprezando por completo as diferenças sociais, econômicas, históricas e culturais individuais ou grupo social infantil.

Polakow e Postman (apud STEINBERG e KINCHELOE, 2004, p. 12) apresentam um exemplo concreto de alguns dos problemas causados por essa generalização inadequada das teorias biopsicológicas da infância:

Considerando os estágios do desenvolvimento biológico da criança como fixos e imutáveis, professores, psicólogos, pais, assistentes sociais e a comunidade em geral viam e julgavam a criança através de uma classificação de desenvolvimento fictícia. As crianças que não "atingiam o 
padrão" seriam relegadas ao grupo de baixa expectativa e desempenho. As que "alcançavam a meta" descobririam que o seu privilégio econômico e racial seria confundido com capacidade.

Ao que nos parece, a superação dessa mentalidade veementemente combatida também pelos pesquisadores da Sociologia da Infância constitui apenas o início da superação de um equívoco com consequências desastrosas para a educação das crianças.

Assim, bem diverso de outros tempos, faz-se necessário pensarmos hoje não em uma infância única, como inadvertidamente buscou-se, e, em muitos casos, busca-se ainda hoje, encontrar/identificar no cotidiano das sociedades. Na contemporaneidade, é imprescindível abrirmos os olhos para o plural que essa categoria etária, geracional e plural exige. Dessa forma, os estudos da Sociologia da Infância têm apontado a necessidade de pensarmos não na infância, na criança, porém nas muitas infâncias, nas muitas crianças que estão espalhadas por aí: infâncias de crianças pobres; infâncias de crianças ricas; infâncias de crianças brancas; infâncias de crianças negras; infâncias de crianças amarelas; infâncias de crianças urbanas; infâncias indígenas; infâncias de crianças do campo, da lavoura, da roça; infâncias de crianças católicas; infâncias de crianças do candomblé e da umbanda; infâncias de crianças das periferias; infâncias de crianças da favela; infâncias de crianças do tráfico; infâncias de crianças da prostituição; infâncias de crianças da rua; infâncias de crianças que trabalham para ajudar a sustentar suas famílias; infâncias de crianças da revolução industrial; infâncias de crianças do pós-guerra; infâncias de crianças órfãs; infâncias de crianças, das muitas crianças que habitam o planeta terra.

Como bem ensina Sarmento (2005, p. 365, 366):

A infância é uma categoria historicamente construída, a partir de um processo de longa duração que lhe atribuiu um estatuto social e que elaborou as bases ideológicas, normativas e referenciais do seu lugar na sociedade. Esse processo, para além de tenso, e internamente contraditório, não se esgotou. É continuamente atualizado na prática social, nas interações entre crianças e entre crianças e adultos.

Entendida dessa maneira, não há dúvida de que ao longo dos tempos e nos diferentes espaços, as diferentes sociedades e civilizações experienciaram diferentes formas de infância e consequentemente de ser criança. De acordo com autores como Ariés (1981) e Cohn (2005), por exemplo, ao longo da história da humanidade, para muitas crianças essa categoria (infância) sequer existiu. São crianças excluídas de sua própria categoria. 
Pensando no nosso tempo, tem sido bem comum observarmos a indicação de que a infância hoje está cada vez mais curta. Um dos autores que compactuam com essa opinião é Postman (1999) que afirma que atualmente estamos nos desvencilhando da imagem bicentenária de criança, e adotando a imagem do jovem adulto. $\mathrm{O}$ intuito desse pesquisador é advertir que, na sociedade contemporânea, as crianças já não querem ser criança mas sim jovens adultos.

Ao que nos parece, esse posicionamento precisa ser visto com cautela, pois ao tentarem escapar dessa condição - ser criança - é provável que, mais uma vez, elas estejam sendo influenciadas pelos valores vigentes na sociedade na qual estão inseridas. Isso fica patente se considerarmos, por exemplo, que no mundo contemporâneo a juventude foi eleita como ícone maior, que impera uma supervalorização do ser jovem em detrimento a todas as outras categorias (criança, adulto, idoso). A legitimação disso está estampada cotidianamente na telinha da tevê, a qual não se cansa de mostrar que ser jovem é sinônimo de atitude. Sob essa ótica, ser criança ou não, não consiste em uma simples escolha das crianças, mas sim em uma implicação social.

Isso ocorre pelo fato de a infância ser uma categoria geracional24 que, caracterizada desta forma, tende a mudar de acordo com o tempo e as realidades em que se dá. "A infância é independente das crianças; estas são actores sociais concretos que em cada momento integram a categoria geracional; por efeito de variação etária desses actores, a 'geração' está continuamente a ser 'preenchida' e 'esvaziada' dos seus elementos constitutivos concretos." (SARMENTO, 2005, p. 364).

A compreensão da infância como uma categoria etária, geracional e plural também tem suas dimensões constitutivas e institucionalizadoras. Um mapeamento dessas dimensões foi feito por Sarmento (2004). Para isso, divide a modernidade em dois momentos: a primeira modernidade e a segunda modernidade.

Na primeira modernidade, as dimensões constitutivas da infância têm implicações de fatores como: criação das instâncias públicas de socialização (a escola pública, o ofício de aluno); a reorganização da família - família protetora (moderna, burguesa, nuclear); a formação de um conjunto de saberes e disciplinas a respeito da infância (pediatria, psicologia do desenvolvimento, pedagogia); a elaboração de um conjunto de procedimentos configuradores da administração simbólica da infância (alimentação, consumo, postura, aceitação em determinados espaços e outras normas de conduta adequadas ao infantil).

\footnotetext{
24 O conceito de geração ao qual nos referimos aqui tem sua referência nos estudos de Sarmento (2005) que o defende como uma variável independente, transhistórica, estando prioritariamente ligada aos aspectos demográficos e econômicos da sociedade (p. 364).
} 
A segunda modernidade é caracterizada por Sarmento (2004) como resultante de um conjunto de rupturas sociais que se inicia com a reestruturação das economias em seguida ao pós-guerra. Essa reconfiguração social, econômica, política e cultural do mundo tem por base algumas ideias fundadoras do espírito da modernidade, como "[...] a crença na razão, o sentido do progresso, a hegemonia dos valores ocidentais, a ideia do trabalho como base social." (p. 15). Para esse autor, essas mudanças implicaram em um processo de reinstitucionalização da infância. Isso ocorreu devido às dimensões constitutivas da infância da primeira modernidade também terem sofrido transformações que implicaram nesse processo de reinstitucionalização.

Em consequência de tal processo, a escola comumente apresenta dificuldade em dar conta da heterogeneidade e dos interesses de suas demandas; a família nuclear entra em crise com o surgimento de novos arranjos familiares; "os saberes e disciplinas sobre a infância" viram-se diante da complexidade de compreensão das novas relações das crianças com o cotidiano. A criação de produtos industrializados, especialmente para elas, ampliou a ação da Indústria Cultural que passou a desenvolver ações de propaganda e marketing com foco no consumo desse público. Isso fez com que grande parte dos saberes fosse convertida também em serviços comercializáveis a ele. Quanto aos "procedimentos configuradores da administração simbólica da infância", estes passaram a um constante paradoxo, pois que se de um lado defende-se o controle da infância e dos sujeitos crianças, de outro é constante a luta pela criação, manutenção e respeito pelos seus direitos.

Esse mar de incertezas que caracteriza a sociedade contemporânea leva à questão: afinal, qual o lugar da criança na sociedade atual? Em resposta a essa pergunta, Sarmento (2004) afirma que o lugar da criança é o lugar das culturas da infância, definidas pelo autor como "[...] modos sistematizados de significação do mundo e de acção intencional realizados pelas crianças, distintos dos modos adultos de significação e acção" (p. 20). Trata-se de um processo dinâmico que "[...] é continuamente reelaborado pelas condições estruturais que definem as gerações em cada momento histórico concreto." (p. 20).

Outro autor que contribui para o entendimento das culturas da infância é Corsaro (2002). Segundo ele, as crianças não apenas reproduzem as culturas dos adultos, como também são protagonistas, pois são capazes de produzir outras culturas (de infância), a partir daquelas. "As crianças apropriam-se criativamente da informação do mundo adulto para produzir a sua própria cultura de pares". E isso "[...] simultaneamente contribui para a reprodução da cultura adulta." (p. 114). A criatividade nessa forma de apropriação das crianças dá-se na medida em que tanto expandem a cultura de pares, como modificam as informações do mundo adulto conforme suas preocupações e de seus pares infantis. 
O reconhecimento de existência das culturas da infância é também o reconhecimento de que mesmo experienciada em tempos e espaços adversos, elas não se dissolveram/dissolvem na cultura dos adultos. Isso também não subtraiu das crianças a identidade plural e a autonomia de ação que garante a elas a condição de atores sociais. Nas palavras de Sarmento (2004), temos que "[...] a infância está em processo de mudança, mas mantém-se como categoria social, com características próprias. [...] há uma 'universalidade' das culturas infantis que ultrapassa consideravelmente os limites da inserção cultural local de cada criança." (p. 19 e 22).

Também nos estudos de Sarmento (2004), verificamos que existem dimensões que constituem e caracterizam essa categoria, contribuindo assim para a manutenção das culturas da infância, além de garantir sua perpetuação ao longo dos tempos e nos diferentes lugares. Para Sarmento (2004), quatro são essas dimensões: a morfológica, a sintática, a pragmática e a semântica:

$\checkmark$ Dimensão Morfológica: formas que assumem os elementos constitutivos das culturas da infância: os jogos, os brinquedos, os rituais, os gestos e as palavras.

$\checkmark$ Dimensão Sintática: regras de articulação entre os elementos simbólicos.

$\checkmark$ Dimensão Pragmática: regras e protocolos das relações de comunicação que se estabelecem entre pares.

$\checkmark$ Dimensão Semântica: referenciação e significação próprias das crianças.

O entendimento dessas dimensões constitutivas das culturas da infância ajuda-nos a compreender melhor que as crianças são seres sociais que, mesmo já nascendo inseridos em uma rede, um contexto social já estabelecido historicamente, por meio do desenvolvimento da comunicação, da linguagem e da interação com os outros (adultos e pares), constroem os seus mundos sociais próprios (CORSARO, 2002). Concebidas dessa forma, ainda com base nos estudos de Sarmento (2004), as culturas da infância também são sustentadas pelos seguintes pilares: a interatividade, a ludicidade, a imaginação do real e a reiteração.

$\checkmark$ Interatividade: A convivência com os pares promove nas crianças a partilha de tempos, ações, representações e emoções, necessária a um mais perfeito entendimento do mundo.

$\checkmark$ Ludicidade: as crianças brincam, contínua e abnegadamente. Contrariamente aos adultos, entre brincar e fazer coisas sérias não há distinção, sendo o brincar muito do que as crianças fazem de mais sério. 
$\checkmark$ Imaginação do real: transposição imaginária de situações, pessoas, objetos ou acontecimentos; fazer de conta é processual permite continuar o jogo da vida em condições aceitáveis para a criança.

$\checkmark$ Reiteração: o tempo da criança é um tempo recursivo. A criança constrói os seus fluxos de (inter)ação numa cadeia potencialmente infinita, na qual articula continuamente práticas ritualizadas ("agora diz tu, agora sou eu”), propostas de continuidade ("e depois...e depois...") ou rupturas que se fazem e são logo suturadas ("pronto, não brinco mais contigo...").

A despeito de os estudos da Sociologia da Infância apresentarem bases estruturadas consistentes que denunciam a urgência de se repensar as concepções de infância e criança, no sentido de legar-Ihes a condição que lhes é devida: uma categoria etária, geracional e plural movida por atores sociais concretos; isto não significa que na sociedade a institucionalização da infância herdada da idade moderna irá ceder espaço sem resistência às culturas infantis.

Essa expressão Culturas Infantis, enquanto legado dos estudos desenvolvidos na Sociologia da Infância, significa o entendimento de que as crianças ao estabelecerem interações sociais, processos de significação e interpretação do mundo em suas práticas cotidianas, desempenham um papel ativo no seu processo de socialização ${ }^{25}$. Contempla a compreensão de que as crianças mais que seres estereotipados, são sujeitos singulares tanto nas suas produções simbólicas como em seus artefatos infantis. (GOUVEA, 2008).

Conforme assinala Dornelles (2005), desde o momento em que a infância passou a ser diferenciada e individualizada, ela passou a ser alvo de intervenções econômicas, campanhas morais e de escolarização. Sarmento (2004) mapeia a existência de basicamente três formas criadas pelos adultos para regular e controlar as infâncias das crianças.

1 - A cultura escolar: códigos e conteúdos próprios, que estabelecem o recorte, seleção, incorporação, hierarquização de saberes e dispositivos de transmissão dos saberes e valores.

2 - A cultura erudita para as crianças: literatura infantil, dança, música clássica, voltadas para crianças.

3 - A Indústria cultural para a infância: literatura infantil, jogos e brinquedos, cinema, bandas-desenhadas, jogos vídeo e informáticos, sites e outros dispositivos da Internet,

\footnotetext{
25 A socialização é entendida neste trabalho como um processo pelo qual um ser humano desenvolve suas maneiras de estar no mundo e de relacionar-se com as pessoas e com o meio que o cerca, tornando-se um ser social. Constitui-se como um processo dinâmico que permite a construção, desconstrução e reconstrução de identidades. (DUBAR, 2005).
} 
serviços variados - de férias, de tempos livres, de comemoração de aniversário, de festas etc.

\title{
1.3 Cultura erudita26, Indústria Cultural e Cultura Escolar: tecendo a teia
}

\author{
É pedagogicamente imperativo que pais, \\ educadores e profissionais da cultura estejam atentos a como filmes (veiculados pela) \\ midia visual são usados e entendidos diferentemente por diversos grupos de crianças. (...) \\ isso sugere que nós desenvoluamos novas formas de aprendizado, de entendimento crítico \\ e leitura da midia visual eletronicamente produzida. Ensinar e aprendera cultura do \\ liuro não é mais a marca do que significa ser instruido. (GIROUX apud \\ STEONBERG e KONCHELOE, 2004, p. 105].
}

Desde o momento em que as crianças foram separadas do mundo dos adultos e limitadas ao espaço do privado, e que surgiu o sentimento moderno burguês de infância, uma série de produções culturais foram criadas para educar (controlar) as crianças. Isso ocorre porque "[...] sem poder brincar livremente pela cidade, a criança perdeu não apenas o espaço físico, mas sobretudo teve alteradas estruturalmente suas condições de produzir e de se relacionar com a cultura, com a sociedade, com a vida política." (PERROTI, 1990, p. 92).

Enclausuradas em suas casas ou em instituições, nos espaços 'do privado', observase a luta constante dos adultos para inserir nos pequenos os saberes legitimados pelas culturas adultas. Ao negar à criança a oportunidade de se relacionar ampla e livremente com o espaço público, "[...] o modelo cultural burguês propõe-lhe, em troca viver tais relações através de uma produção cultural preparada por adultos especialmente para ela, e a ser consumida com os referentes e nos limites dos espaços privados." (PERROTI, 1990, p. 98). Dessa maneira é que nos foi legada a prática que ainda hoje perdura cotidianamente, uma avalanche de produtos culturais, como livros infantis, música e dança clássica e popular, teatro para crianças etc., que é despejada no dia a dia para o consumo das crianças.

\footnotetext{
26 A expressão cultura erudita voltada para crianças é compreendida aqui como algo que abarca produtos culturais que propagam ideologias do que é politicamente correto na condição de criança em uma determinada sociedade. Instrumentos de manutenção de uma ideologia conveniente para o Estado e grupos hegemônicos do que é ser criança.
} 
Quanto ao teor dessa cultura erudita cuidadosamente pensada e oferecida ao consumo infantil, Oliveira (2008) afirma que esta tinha/tem objetivos claramente definidos. Quanto aos livros, por exemplo, sua função maior era incutir e propagar valores, ideais e normas de conduta. Dessa maneira, dos contos de fadas às cantigas de roda, das fábulas aos contemporâneos áudios-livro, são todos produtos culturais profundamente marcados por uma conotação moralizante que deve atuar diretamente na formação da criança.

Apesar de ter sido pensada como uma estratégia de fiscalização e controle infantil das crianças, a cultura erudita não atinge a todos com seus bens, pois o mundo das contradições culturais, políticas e econômicas é também o mundo das contradições sociais. Em outras palavras, a cultura erudita pensada pelos adultos para as crianças não é acessível a todas as infâncias, a todas as crianças. Consequentemente, às crianças menos favorecidas, excluídas dos bens dessa cultura para a infância, geralmente o que resta é a ilusão de acesso e pertencimento social promovida pela Indústria Cultural para a infância por meio das mídias, como a televisiva principalmente.

No plano das aparências, pode até parecer louvável a preocupação da Indústria Cultural com as crianças excluídas socialmente, porém é preciso atentar para a forma como os produtos da cultura erudita para crianças são apresentados nesse formato mais 'acessível'. Comumente, o que se apresenta é apenas um resumo, uma síntese, por vezes mal elaborada que mais vulgariza que acessibiliza a obra original aos pequenos. A exemplo do que falamos, enquanto as crianças com maior poder aquisitivo têm acesso a obras completas de Monteiro Lobato, as crianças pobres têm acesso apenas à versão televisiva.

Soares (1996), em seus estudos, contribui decisivamente para a compreensão dessa dinâmica em que a Indústria Cultural sorrateiramente ocupou o espaço e, em alguns casos, transformou radicalmente alguns produtos da cultura erudita produzida para crianças na sociedade contemporânea. Segundo ele:

\footnotetext{
A globalização da economia atinge de forma direta o mundo da cultura. Os bens simbólicos (difundidos através de filmes, programas de TV e de rádio, livros, revistas e jornais) já não escapam a uma subordinação inapelável à nova prática econômica, alimentando o imaginário da maior parte dos seres humanos de todas as raças, religiões e poder aquisitivo. (p. 10).
}

Afigurada dessa maneira, a um olhar mais atento, torna-se visível que na sociedade atual, profundamente marcada pela ação das mídias, alicerça-se uma tentativa de globalização da infância. Esse processo decorre das ações de marketing agressivo promovido pela Indústria Cultural na promoção/divulgação de produtos e serviços da cultura 
industrial para as infâncias do mundo inteiro. A dinâmica da Indústria Cultural em uma sociedade capitalista globalizada marcada por uma economia liberal, como é o nosso caso, é esclarecida em toda sua dimensão por lanni. (1999):

O que singulariza a grande corporação da mídia é que ela realiza limpidamente a metamorfose da mercadoria em ideologia, do mercado em democracia, do consumismo em cidadania. Realiza limpidamente as principais implicações da Indústria Cultural, combinando a produção e reprodução do capital; e operando decisivamente na formação de "mentes" e "corações", em escala global. (p. 17).

Dentre os meios utilizados para isso, o principal mecanismo é a tevê. Esse veículo de comunicação no Brasil atinge mais de $90 \%$ dos lares brasileiros. É tamanha sua importância e abrangência que a televisão tem em nosso país, que somamos mais aparelhos de tevê que a Argentina, o Canadá e o México juntos ${ }^{27}$. Temos, assim, um dos maiores sistemas de tevê aberta do planeta.

Soma-se a essa abrangência massificadora assumida por essa mídia no Brasil o fato de ainda sermos uma sociedade de analfabetos (reais e funcionais). Essa realidade foi verificada por uma pesquisa realizada em 2001, pelo Instituto Paulo Montenegro ${ }^{28}$, a qual mostrou que, em nosso país, apenas $26 \%$ das pessoas alfabetizadas sabem exatamente 0 que leem e o que escrevem; os demais, 74\% da população, ou não têm nenhuma noção de leitura e escrita ${ }^{29}$, ou são teoricamente alfabetizados, mas não compreendem o que leem. Com uma população caracterizada, as histórias que a tevê conta acabam atingindo a população quase que de forma universal, sem distinção social, racial, religiosa, cultural, muito menos etária.

Partindo disso, é razoável inferirmos que poucos espectadores dessa mídia compreendem com propriedade a dinâmica de funcionamento. Com isso, a televisão acaba exercendo um poder extraordinário sobre as decisões sociais, econômicas, culturais e políticas em nosso país, talvez também em todo o globo, passando a constituir uma espécie de poder paralelo. Na perspectiva de Martin-Barbero (2002, p. 11): "[...] atravesados por las lógicas del mercado los medios de comunicación constituyen hoy espacios decisivos de la visibilidad y del reconocimiento social. Pues más que a sustituir, la mediación televisiva ha entrado a constituir una escena fundamental de la vida pública".

\footnotetext{
27 De acordo com dados da PWC Consulting publicados no Jornal Valor Econômico.

28 Entidade criada pelo Ibope em parceria com a com a ONG Ação Educativa.

29 A Pesquisa Nacional por Amostra de Domicílios de 2005 (Pnad) mostrou que, em termos absolutos, havia 14,8 milhões de analfabetos em 2002, e em 2005 este número caiu para 14,6 milhões.
} 
Inserido nessa condição social, também o universo infantil não escapa dos apelos da Indústria Cultural e das ações que promove por meio dos meios de comunicação. A respeito dessa questão, alerta-nos Sarmento (2004, p. 18):

\begin{abstract}
Questão central é [...] a da constituição do mercado de produtos culturais para a infância (programas de vídeo, de televisão, cinema, desenhos animados, jogos informáticos, jogos de construção, literatura infanto-juvenil, parques temáticos, etc.). Estes produtos acompanham o incremento comercial de outros produtos de consumo para as crianças (moda infantil, fast-food, guloseimas, brinquedos, serviços recreativos, material escolar, mobiliário infantil, etc.), a ponto de constituírem um dos segmentos de mercado de maior difusão mundial, em torno do qual se estabelecem algumas das mais difundidas cadeias de franchising, que são mesmo, por vezes, recordes de investimento econômico (por exemplo: a Euro Disney).
\end{abstract}

Na perspectiva de Belloni (2007, p. 60): “Embora a criança seja, sem dúvida, um ator ativo e criativo em seu processo de socialização, não se pode minimizar ou praticamente ignorar [...] a ação sistemática e objetiva das instâncias de socialização [...]". Como exemplo dessas instâncias, a autora destaca as mídias que indelevelmente impregnam as culturas da infância na sociedade atual.

Em consonância, Penteado (1991), Martín-Barbero (2002), Sarmento (2004) e Belloni (2007) compactuam com a ideia de que essa hegemonia dos meios de comunicação, no meio social, leva a um conflito em que a educação das crianças, comprometida com os valores da cidadania, acaba sendo desvirtuada silenciosamente em nome dos interesses particularistas e mercadológicos da Indústria Cultural, das grandes emissoras e seus anunciantes, que buscam legitimá-los como interesses de um coletivo universal para um suposto bem estar da criança.

A estratégia de mercantilizar a infância por meio de produtos e serviços, alertada por Sarmento (2004), sinaliza o interesse da cultura industrial e da Indústria Cultural em tornar legítima uma única infância, mundial, consumidora, globalizada. Assim configurada, a produção em série e sua divulgação em massa não encontram fronteiras comerciais. Com isso, as crianças de segmentos sociais com poder aquisitivo maior, em todo o globo: "[...] coleccionam cartas Pokemon, veem desenhos animados dos estúdios japoneses, brincam nas consolas de jogos da Mattel, leem Harry Potter, calçam ténis Nike e vestem blusas da Benetton 0 a 12 ou da Chicco, alimentam-se do Happy Meal da Mac Donald's e veem pelo natal as super produções dos Estúdios Disney." (p. 18).

O processo de mercantilização da infância é tão insidioso que atinge a todas as crianças, independente do segmento social ao qual estão inseridas. Assim, atinge desde 
aquelas que têm poder aquisitivo para usufruir dos bens de consumo legitimados pela Indústria Cultural como válidos na sociedade, até aquelas que cotidianamente convivem com a escassez de recursos financeiros, em alguns casos, até mesmo aquelas que a sobrevivem abaixo da linha da pobreza.

Essa dinâmica é perfeitamente compreensível se considerarmos que com a sofisticação das ações da indústria cultural, potencializada pela propaganda e pelo marketing, "[...] mesmo quem não consome nenhum dos objetos alardeados pela publicidade como se fossem a chave para a felicidade, consome a imagem deles. Consome o desejo de possuí-los." (KEHL, 2004, p. 61). Esse desejo, em nações marcadas por uma economia liberal e por profundas desigualdades sociais, como é o nosso caso no Brasil, acaba gerando demanda e alimentando outro mercado, o paralelo, informal, que cada vez aprimora sua capacidade de produzir imitações de produtos originais, das marcas legitimadas como válidas pela mídia. Depreende-se então que, consumindo produto original ou pirata, o cidadão "Consome a identificação com o 'bem' (mercadoria), com o ideal de vida que eles supostamente representam." (KEHL, 2004, p. 61).

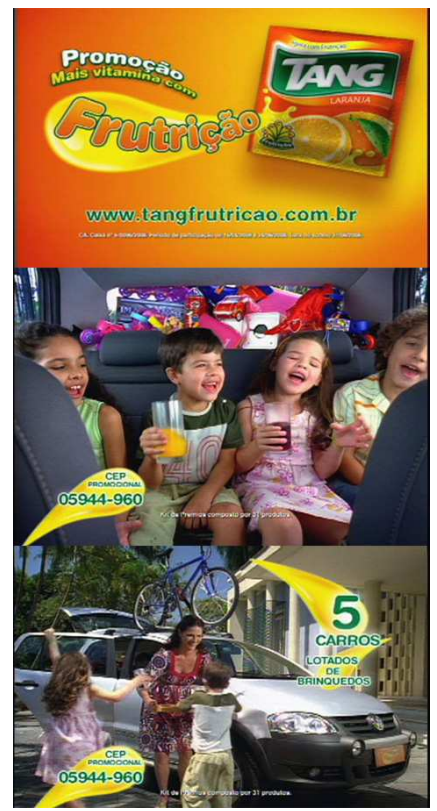

Figura 17: Imagem da Campanha do refresco em pó Tang que em 2008 fez uma promoção para dar carros cheios de prêmios. Com o slogan "Mais Vitamina com Tang Frutrição". A ação de marketing contou com peças para rádio, internet e TV. Na publicidade de TV, crianças tristonhas cantando a canção "Eu não tô aqui pra sofrer. Vou sentir saudade pra quê? Quero ser feliz. Bye bye, tristeza. Não precisa voltar". Recobravam sua alegria "de criança" ao tomarem o suco da marca Tang. A mensagem: só é feliz quem bebe refresco Tang. ${ }^{30}$

Pode-se observar nesse e em muitos outros exemplos que, como outros públicos, o público infantil também não escapa dessa dinâmica mercadológica midiática. A criação de

${ }^{30}$ Disponível em: <http://www.esquadraoverdetang.com.br/?gclid=CO316uvBmK4CFUWQ7QodyAyVLQ>. Acesso em: 03/02/09. 
um mercado que busca ardilosamente atender aos desejos infantis faz com que hoje as crianças logo cedo sejam convidas a gostar de determinadas marcas e dominar capitais culturais que geralmente são ignorados pela cultura dos adultos. Conforme adverte Sarmento. (2004, p. 366):

\begin{abstract}
A introdução dos jogos vídeos e informáticos alterou parcialmente o tipo de brinquedos e o uso do espaço-tempo lúdico das crianças, gerou novas linguagens e desenvolveu as apetências do consumo, que não podem deixar de ser consideradas na análise contemporânea das culturas e das relações de pares das crianças, nomeadamente pelos efeitos no aumento da assimetria do poder de compra e nas desigualdades sociais, com impactos na composição de uma "infância global", consumidora dos mesmos produtos, sobretudo os emanados da indústria cultural para a infância, mas com profunda heterogeneidade interna.
\end{abstract}

Mesmo concordando que a criança não é uma consumidora passiva da programação televisiva, pois caminhamos em consonância com Corsaro (2002) que defende que: "[...] as crianças não se limitam individualmente a interiorizar a cultura adulta que lhe é externa [...] as crianças tornam-se uma parte da cultura adulta [...] e contribuem para a sua reprodução através das negociações com adultos e da produção criativa de séries de culturas de pares com outras crianças." (p. 113).

Em se tratando do apelo da Indústria Cultural, sem uma ação mediadora da família, da escola, o encantamento pelo apelo publicitário ao consumo, massivamente veiculado pelo espetáculo televisivo, e recheado por produtos e serviços desenvolvidos e mostrados para as crianças, é quase inevitável.

O consumo da tevê torna-se mais convidativo ainda em uma sociedade, como a nossa, cada vez mais violenta, em que as brincadeiras comuns da infância, profundamente marcadas pelo lúdico, pela troca, pela socialização, pela criação, realizadas em espaços abertos como quintais, parques, praças etc., paulatinamente se tornam mais raras, dando lugar hoje a uma infância vivenciada em espaços fechados, cada vez mais marcada por artefatos eletrônicos: tevê, games, Internet, telefone celular, MP3, jogos em lan-house, chats eletrônicos etc. Uma infinidade de produtos diariamente massificados pela Indústria Cultural. Esses são hoje os ícones constitutivos dessa categoria: a infância. Para Chauí (1996), seguindo a dinâmica da sociedade capitalista, cabe aos meios midiáticos estimular de todas as formas possíveis o imaginário das crianças com a finalidade de introduzir nestes indivíduos a necessidade de consumo e transformá-los em crianças consumidoras. 
Sarmento (2004) também comunga dessas ideias apontando algumas consequências dessa ação: "O imaginário infantil tem vindo a ser profundamente influenciado e constituído pelo mercado de produtos culturais para a infância, mercado esse que entronca na globalização social e cultural." Mais adiante, alerta o pesquisador: "A colonização do imaginário infantil pelo mercado é um dado da sociedade contemporânea que não se pode ignorar." (p. 25).

Um exemplo disso encontramos em Giroux (2004) que, analisando a ação da Disney no contexto social infantil, adverte que as crianças experimentam da sua influência cultural em virtude da profusão de representações e de produtos encontrados em vídeos domésticos, shoppings, filmes "educacionais", bilheterias, programas populares de tevê, restaurantes familiares, e outras formas de extensão da marca. Guarnecidos dessas estratégias de divulgação massiva, os aparentemente inofensivos filmes de Disney sutilmente inspiram: "A autoridade e a legitimidade culturais para ensinar papéis, valores e ideais específicos, tanto quanto o fazem os locais mais tradicionais de ensino, como escolas públicas, instituições religiosas e a família." (p. 89).

Ainda a respeito das muitas ideologias que são impregnadas nos produtos destinados a crianças e adolescentes, Buckingham (2007) sinaliza que audiovisuais pueris como os filmes da Disney e de Spielberg, hoje consumidos em larga escala por famílias (adultos e crianças) de todo o mundo, "[...] podem ser vistos precisamente como formas de unir estes dois públicos. Eles contam a adultos e crianças histórias muito sedutoras a respeito dos significados relativos da infância e da idade adulta." (p. 23). Em outras palavras, por meio da linguagem imagética, atendendo aos interesses estatais e mercadológicos, a Indústria Cultural legitima modelos ensinando como ser adulto e como ser criança na sociedade contemporânea.

Outro aspecto que contribui para a constituição dessa infância consumidora dos produtos alardeados pela Indústria Cultural no espetáculo midiático televisivo é o fato de as principais instituições reguladoras, formadoras na infância, a família (independente de seu arranjo) e a escola, estarem distantes da realidade vivenciada pelas crianças, aos poucos deixando de ser referenciais para elas. A escola, presa a um currículo e/ou a um método de ensino, na maioria das vezes, tem dificuldade em abarcar essa complexa realidade social da vida infantil; a família, preocupada apenas em formar, em educar seus filhos para ter sucesso na vida adulta, também já não dispõe de tempo e espaço para oportunizar uma educação mais presente aos seus filhos. Configuradas dessa forma, essas instituições vêm progressivamente se distanciando do cotidiano da realidade vivenciada pelas crianças, deixando um vazio propício para o surgimento de uma nova e "competente formadora e socializadora": a televisão. 
De acordo com o que assevera Belloni (2007, p. 59), dentre os muitos fatores que levaram a mudanças profundas na família atual, e que implicaram diretamente no processo de socialização desempenhado por ela, destacam-se: "A maior participação da mulher no mercado de trabalho, as mudanças na estrutura familiar (divórcio, famílias recompostas, monoparentais) e a importância das mídias de massa". Essa indicação também é encontrada em Caparelli (2002) quando atribui ao surgimento dos meios de comunicação de massa o declínio da relevância da família e da escola como mediadoras do conhecimento. Mesmo sem saber dimensões exatas, esses e outros pesquisadores mostram que transformações ocorridas no processo de socialização desempenhado pela família contemporânea sofreram, inegavelmente, influência das tecnologias de informação e comunicação.

Lazar (1999, p. 102) também está em consonância com tal indicação. Segundo ela:

\begin{abstract}
Inicialmente a família era o lugar da transmissão dos saberes, do saber viver. A escola veio depois. Ela ofereceu à criança outro lugar de transmissão social, onde os valores não são exatamente os mesmos dos pais, onde os modos de interação não são os mesmos da família. $O$ aparecimento da televisão e de toda uma série de mídias destinadas às crianças aumentou ainda mais a complexidade da socialização.
\end{abstract}

A exemplo do que estamos vivenciando no campo da educação inicial das crianças atualmente, Fischer (2007, p. 297) afirma que "[...] crianças hoje se alfabetizam numa época em que as próprias tecnologias de informação e comunicação nos forçam a pensar de outra forma o que muitos filósofos e artistas já discutiram há pelo menos 30 ou 40 anos".

Ainda a respeito dessa questão, Martín-Barbero (2004) concorda com Belloni (2007), Lazar (1999) e Fischer (2007) em que a complexidade da dinâmica da sociedade atual, marcada por mudanças profundas nos valores e nas formas de socialização, contribuiu para um quadro educacional que merece muita atenção. Segundo ele, "[...] ni los padres constituyen ya el patrón de las conductas, ni la escuela es el único lugar legitimado del saber." (p. 45).

A ação da família na mediação do consumo de mídias é fundamental na medida em que isto implicará diretamente na capacidade que a criança terá de assimilar e avaliar o conteúdo dos filmes, não apenas no sentido moral, mas também no de sua compreensão da realidade social representada.

Desse modo, a ação educadora da família é imprescindível para que se garanta o exercício da cidadania das crianças. Não há dúvida do papel indispensável da escola, isto é indiscutível, porém, esta instituição "[...] não substitui a ação da família. As crianças 
precisam de atenção dos pais e familiares, da troca de afeto e de conhecimento, partilhando valores, crenças, costumes e tradições que dizem respeito às famílias e às comunidades nas quais se inserem." (CORSINO, 2005, p. 212). O enfrentamento do desafio da educação da infância na sociedade contemporânea implica então em uma ação conjunta dessas duas instituições que não raro encontram-se desarticuladas: família e escola.

É possível pensar que essa gradual saída de cena das famílias consista também em uma tendência resultante da massificação, por parte da Indústria Cultural, de uma infância globalizada, universal que, independente de tempo e lugar, necessita dos mesmos cuidados, ideologias, produtos e serviços. Assim, atendendo a esse apelo, conscientes ou não, as famílias das classes média e alta submetem seus filhos pequenos a rotinas estressantes que começam na segunda e invadem os fins de semana: balé, caratê, natação, escola, aula particular, campeonato disso, campeonato daquilo. Dessa forma, não há dúvida de que as crianças estarão preparadas para a vida adulta, para o competitivo mercado de trabalho da sociedade tecnológica globalizada, pois já na infância estão acostumadas com o estresse da constante corrida contra o tempo, típica da cultura dos adultos.

Atenta a essas relações, alerta Sayão (2009, p. 12): "Colocamos muito cedo na vida de nossas crianças o consumo e a noção de economia, a competição acirrada, a responsabilidade de fazer escolhas e de arcar com elas, a vida individual como valor máximo e outros aspectos de nossa cultura". A psicóloga também chama a atenção para o fato de que, geralmente, as crianças também não serem poupadas dos dramas e das pequenas e grandes tragédias que assolam nossa sociedade, sejam as restritas ao âmbito familiar ou àquelas cotidianamente noticiadas nos programas de tevê.

As crianças de classe baixa também são vitimadas pela escassez de tempo e espaço para ser criança. A diferença que se instaura é que, enquanto as famílias mais abastadas inserem uma agenda de atividades na educação de seus filhos, as crianças pobres são, muitas vezes, obrigadas a trabalhar e assumir responsabilidades precocemente, para assim contribuírem para a manutenção do arranjo familiar em que vivem: vendem balas no trânsito; catam papelão nas ruas; ajudam seus pais na roça; são responsáveis pelo serviço doméstico e por cuidar dos irmãos mais novos.

É nesse contexto que a programação da televisão acaba tendo uma ação marcante no cotidiano das crianças. Com Ferrés (1996, p. 79-80), aprendemos que "[...] a televisão produz seus maiores efeitos socializadores nas camadas sociais e culturais mais frágeis. Em consequência, as crianças são umas presas fáceis e influenciáveis do meio". A falta de uma educação mediadora por parte das famílias, escolas e outras instituições aumenta a 
possibilidade de manipulação, porque quanto menos educação, mais ócio incontrolado e, portanto, mais tempo de consumo desse meio.

Considerando a atual circunstância em que a infância contemporânea se insere, a educação das crianças hoje exige dos profissionais da educação infantil uma formação com sólidos fundamentos sociológicos, em conjunto com biológicos e psicológicos, que possibilitem ao profissional em exercício lidar com a criança enquanto um ser biopsicossocial real, que está inserido em grupo social e uma classe social. Trata-se de uma condição indispensável para a superação de práticas tradicionais de ensino, comumente massivas, diretivas e centralizadas.

$\mathrm{Na}$ dinâmica desse processo, muitas vezes inadvertidamente, priva-se a criança de dois fatores fundamentais para o desenvolvimento de sua autonomia: a brincadeira e o humor descompromissados, sem hora e tempo marcados, cronometrados. Vale retomar aqui as palavras de Kehl (2004), quando indica que a brincadeira floresce no tempo vazio. Mais ainda: floresce quando a cabeça está vazia. Ela chama a atenção para as muitas formas de repressão, castração e controle da brincadeira. De acordo com ela: "Cabeça vazia, oficina do diabo", diziam as avós de antigamente, conscientes de que para impedir uma criança de pensar bobagens, travessuras e aventuras, era preciso ocupá-la com alguma coisa. "Mas o diabo que se engendra numa cabeça vazia (de uma criança) é o capetinha do faz de conta, do devaneio, da pura alegria de viver". ${ }^{31}$

Brougere (1998), já há algum tempo, vem defendendo a cultura lúdica como algo inerente à infância. Ele define cultura lúdica como um conjunto de procedimentos que permitem tornar a brincadeira o jogo possível. Ao indicar ser própria da infância, afirma que dispor de uma cultura lúdica é dispor de certo número de referências que permitem interpretar como jogo atividades que poderiam não ser vistas como tais por outras pessoas (adultas). Além disso, visto resultar de uma experiência lúdica, essa cultura é então produzida pelo próprio sujeito social que é a criança.

Em seus estudos, esse autor ${ }^{32}$ adverte para as implicações das mídias na constituição da cultura lúdica.

Alguns elementos parecem ter uma incidência especial a respeito da cultura lúdica. Trata-se hoje da cultura oferecida pela mídia, com a qual as crianças estão em contato: a televisão e o brinquedo. A televisão, assim como o brinquedo, transmite hoje conteúdos e às vezes esquemas que contribuem para a modificação da cultura lúdica que vem se tornando

\footnotetext{
31 Disponível em <http://www.aomestrecomcarinho.com.br>. Acesso: 27 de jul. de 2004.

32 Disponível em: <http://www.scielo.br/scielo.php?script=sci_arttext\&pid=S0102-25551998000200007>. Acesso: 27 de jul. de 2004.
} 
internacional. Mas, embora arriscando-me a repetir, eu diria que o processo é o mesmo. Barbie intervém no jogo na base da interpretação que a criança faz das significações que ela traz. De certa forma, esses novos modos de transmissão substituíram os modos antigos de transmissão oral dentro de uma faixa etária, propondo modelos de atividades lúdicas ou de objetos lúdicos a construir. Não estamos dizendo que o sistema antigo foi menos impositivo de forma alguma.

Apesar de não serem consumidores passivos dos conteúdos veículados pela tevê, e de serem submetidos a outros processos de socialização, as implicações da televisão nas culturas infantis no Brasil também refletem o fato de que essa mídia atinge em média 97,1\% dos lares brasileiros ${ }^{33}$. A abrangência que a televisão tem é tanta que o país concentra o $4^{\circ}$ maior mercado de tevê aberta do mundo. São mais de 100 milhões de aparelhos de televisão espalhados por todo o país ${ }^{34}$.

A educação escolar das crianças, nesse contexto de muitas contradições, tem diante de si um grande desafio. Pois, além dessa ação massiva da Indústria Cultural para crianças que as atinge diretamente devido à carência de uma medicação mais efetiva da escola e da família, não podemos perder de vista que no mundo em que vivemos hoje, se de um lado defende-se a democracia; de outro se nega a participação igualitária da maioria dos indivíduos, independente da categoria em que se inserem: crianças, adolescentes, jovens, adultos ou idosos. Em outras palavras, impera certo desequilíbrio entre o cidadão do mundo - cidadão globalizado - e o homem restrito ao seu próprio meio, impossibilitado não apenas de ver reconhecidos seus direitos, mas também de exercer a sua própria cidadania, já que a exclusão é tanta que ignora até mesmo que tem direitos. (BACCEGA, 1998).

Introduzida nesse contexto, à escola cabe a função de assegurar aos alunos saberes científicos que oportunizem uma melhor compreensão da realidade. Para isso, são necessários professores dotados de saberes que permitam uma prática pedagógica mediadora capaz de transformar as concepções alternativas, espontâneas, pouco refletidas de perceber e se apropriar da realidade, comumente apresentadas pelos alunos, em concepções mais críticas da realidade.

Para Garrido (2001), uma escola atenta à sua função social deve incentivar que seus professores desenvolvam práticas docentes que favoreçam e estimulem esse processo de desconstrução e reestruturação das formas de pensar e de compreender a realidade, deve

\footnotetext{
33 De acordo com pesquisa realizada pelo Programa Nacional de Conservação de Energia Elétrica (Procel), da Eletrobrás. A investigação foi desenvolvida entre dezembro de 2004 e julho de 2006, em 18 Estados brasileiros.

34 Uma nova TV com alta definição, mobilidade e interatividade. Disponível em:

<http://www.abert.org.br/D_mostra_clipping.cfm?noticia=15043>. Acesso em: 28/06/2006.
} 
proporcionar também aos pequenos outras maneiras de se relacionar e de dar sentido ao mundo que vivenciam.

Sensíveis a esses princípios referenciadores, uma prática docente mediadora, conforme vimos caracterizando, não pode desprezar as representações que os alunos cotidianamente trazem para o ambiente escolar. Afinal, ao oferecer um ambiente educativo rico em diálogo, reflexão e participação, o professor assegura às crianças condições para que possam "[...] tomar consciência de suas próprias atividades cognitivas, aprendendo a geri-la e aperfeiçoa-la." (GARRIDO, 2001, p. 126).

Compromissada com uma educação cidadã, a escola pode desempenhar um papel fundamental na promoção desse equilíbrio social apontado por Baccega. Para isso, dentre outras coisas, a escola precisa proporcionar aos seus alunos um processo educativo que também contemple uma educação midiática. Pois é ela que pode formar o cidadão, na medida em que tem a possibilidade de desenvolver a capacidade para interpretar e entender criticamente as informações à medida que ensina a inter-relacioná-las e transformá-las em conhecimento.

Em outras palavras, é na escola que a criança e o adolescente deverão ser formados não para a cidadania, mas na cidadania, condição indispensável para inserir-se dignamente na sociedade contemporânea. A respeito dessa situação, Citelli (2005) entende que mais que um direito, trazer os meios de comunicação - como o rádio, a tevê - e as tecnologias mais avançadas - como o computador - para a sala de aula é um caminho para a promoção da cidadania dos aprendizes.

Em um mundo em que o simbólico dá lugar ao signo, em que as mediações educativas tornaram-se pouco referenciais e em que as tecnologias midiáticas tornaram-se um parâmetro para a existir, adultos e crianças tiveram/têm seus imaginários transformados, o que implicou e ainda hoje implica em outras maneiras de ser, sentir, pensar, sociabilizar, lazer, ensinar e aprender. Consequentemente, emergem outros desafios epistemológicos para a construção do conhecimento. (GARRIDO, 2001).

Sobre a importância de a escola proporcionar essa educação midiática, MartinBarbero (2005, p. 62) faz o seguinte alerta:

O mais grave dos desafios que a comunicação propõe hoje à educação é que, enquanto os filhos das classes mais altas conseguem interagir com o novo ecossistema informacional comunicativo a partir da própria casa, os filhos das classes populares - cujas escolas não têm, em sua imensa maioria, mínima interação com o ambiente informático, sendo que para eles a escola é o espaço decisivo de acesso às novas formas de conhecimento - 
acabam excluídos do novo espaço laboral e profissional que a cultura tecnológica configura. Daí a importância estratégica que assume uma escola capaz, hoje, de um uso criativo e crítico dos meios audiovisuais e das tecnologias informáticas.

Faz-se necessária, então, a superação de uma cultura escolar baseada em uma lógica de estoque que nega aos alunos a condição de sujeitos sociais ativos, concebendo-os simplesmente como receptáculos dos saberes legítimos que supostamente detém o professor, o verdadeiro dono do saber. É preciso ultrapassar esse modelo de escola em que se perpetuam paradigmas tradicionais de ensino-aprendizagem, caracterizados por práticas diretivas, não participativas. Se pretendemos uma escola transformadora, socialmente inclusiva, ela deve ter por foco um processo educativo participativo, interativo que não privilegie não apenas os conteúdos das disciplinas do currículo, mas que considere o contexto em que ocorre o processo de ensino-aprendizagem: uma sociedade globalizada, complexa, indelevelmente marcada pela ação das tecnologias midiáticas. Nas palavras de Citelli (2005, p. 84): "Trazer os meios para a escola significa incorporar uma nova maneira de organizar a sociedade e reconhecer outras dinâmicas da cultura, agora marcadas por forte urbanização e distintas relações de tempo e espaço".

$\mathrm{Na}$ perspectiva de construirmos uma escola transformadora, que viabilize caminhos para alcançarmos o equilíbrio social indispensável ao exercício da cidadania, faz-se imprescindível que três objetivos básicos sejam contemplados pela educação escolar: primeiro, a formação de recursos humanos; segundo, a construção de cidadãos; e terceiro, o desenvolvimento de sujeitos autônomos. (HOPENHAYAN apud MARTIN-BARBERO, 1999).

Refletindo a respeito desses três objetivos propulsores de uma participação ${ }^{35}$ social mais efetiva, condição indispensável à prática da cidadania, Martin-Barbero (1999, p. 39) faz as seguintes considerações:

$\checkmark$ Quanto ao primeiro objetivo, a educação não pode dar as costas para as transformações no mundo do trabalho, para os novos conhecimentos que a produção mobiliza, para as novas figuras que, de forma acelerada, recompõem o campo e o mercado das profissões. Não se trata de amoldar a formação à adequação dos recursos humanos para a produção, mas a escola deve assumir os desafios colocados pelas inovações técnicoprodutivas e de trabalho quanto a novas linguagens e conhecimentos. Seria suicida a escola alfabetizar para uma sociedade cujas modalidades produtivas estão desaparecendo.

35 À luz dos estudos de Bordenave (1994), neste trabalho entendemos o conceito de participação como fazer parte, tomar parte ou ter/ser parte de algo. 
$\checkmark$ Em segundo lugar, a construção de cidadãos significa uma educação capaz de ensinar o mundo de forma cidadã, ou seja, capaz de criar jovens com mentalidade crítica, desajustadora da acomodação na riqueza e da resignação na pobreza; uma educação que remove a cultura política para que a sociedade não busque salvadores, mas gere formas de convívio e respeito para com as regras do jogo da cidadania, desde as leis de trânsito até o pagamento de impostos.

$\checkmark$ E, em terceiro lugar, a educação deve desenvolver sujeitos autônomos. Diante de uma sociedade que se massifica estruturalmente, uma sociedade que tende a homogeneizar até mesmo quando cria possibilidades de diferenciação, a possibilidade de ser cidadão é diretamente proporcional ao desenvolvimento de sujeitos autônomos, ou seja, pessoas livres tanto internamente quanto em suas decisões.

\title{
1.4 As infâncias contemporâneas, educação com, para e por meio de mídias e formação de professores
}

\author{
A constatação de que existem convergências e divergências entre \\ as culturas midiáticas e das escolas, não impede, contudo, que se busque, através de atitudes novas $e$ \\ desafiadoras, aqueles procedimentos de aproximação entre os dois sistemas e que contribua para \\ tornar mais eficaz a ação educativa. [...] trata-se de fazer com que o rádio, a televisão, o jornal, as \\ tecnologias digitais e informacionais ao mesmo tempo entrem nas salas de aula e delas sofram os \\ influxos que a atenção crítica e reflexiva de um saber academicamente sustentado e socialmente

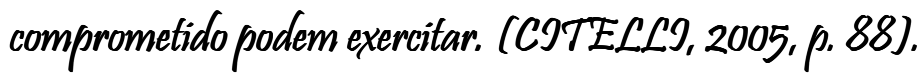

Esse diálogo urgente e necessário entre a cultura escolar e a cultura midiática no sentido da promoção de uma educação com, para e através dos meios de comunicação já há algum tempo tem sido objeto de estudo na academia. Assim, profissionais de diversas áreas do conhecimento, com diferentes enfoques e fundamentação teórica de pesquisa, investigam possíveis convergências, possibilidades de diálogo e divergências entre as áreas de educação e comunicação. Isso faz com que também uma variedade de nomes tentem abarcar com propriedade esse hoje considerado campo de investigação e intervenção que, por conta dessa diversidade de olhares, acaba sendo detentor de muitos nomes: "Educomídia”, "Mídia educativa”, "Educomunicação”, "Comunicação educativa”, ‘Educação midiática" etc.

Para Citelli (2005, p. 86), com referência nos estudos de Soares (1999) que trata das variáveis que são abarcadas pela pesquisa desenvolvida nessa área de convergência, existem basicamente quatro eixos de investigação nesse campo: Educação para a comunicação, Mediação tecnológica na educação, Gestão comunicativa, e Reflexão 
epistemológica. Nesta pesquisa, comungamos com outros que reivindicam a urgência de uma ação educativa, desenvolvida por meio de uma Pedagogia da Comunicação, e viabilizadora de uma educação com, para e por meio de mídias na escola. A implementação de uma ação educativa, conforme delineamos, deve oportunizar às crianças um processo de ensino-aprendizagem formal que permita em primeiro lugar que se desenvolva nelas um consumo mais vivencial, sensível e reflexivo daquilo que veem na tela da tevê; segundo, que assegure às crianças processos socializadores que as concebam como sujeitos sociais agentes, com condições e direito de participação tanto de seu processo educativo como da vida social.

Entendemos que essa educação deve ter início já na Educação Infantil que, "[...] como primeira etapa da educação básica, que tem como finalidade o desenvolvimento integral da criança até seis anos de idade, em seus aspectos físico, psicológico, intelectual e social, complementando a ação da família e da comunidade." (grifo nosso). Isso que preconiza a LDBEN atual (Lei de Diretrizes e Bases da Educação Nacional, 9394/96), no seu Art. 29, a respeito dos objetivos da Educação Infantil, constitui atualmente um grande desafio para os profissionais que atuam nesta modalidade de ensino, o que se justifica pelo fato de que além das habilidades inerentes ao espaço escolar, devem também educar as crianças com, para e por meio de mídias, pois é inegável que hoje, antes de virem para a escola, as crianças já estão "alfabetizadas" pelas imagens veiculadas nesses meios, em especial a televisão. (BUCCI, 2002).

Seguindo a mesma linha de pensamento, considera Condry (apud GONET, 2004, p. 35-36):

\begin{abstract}
A escola deve ensinar as crianças a utilizar a televisão, quer se trate de programas ou da publicidade. É necessário explicar-lhes que uso se pode fazer dela, dizer-lhes quando ela não serve para nada. Se elas compreenderem que a aquisição de bens materiais não é o alvo supremo da existência e que os valores pregados pelos programas e pelas publicidades televisivas estão em contradição com o que eles aprendem na escola, isso já será alguma coisa. Em vez de fazer como se a televisão não existisse, a escola deveria propor às crianças discutir programas e ideias, bons ou maus, que Ihes são apresentados. Ela deveria implementar programas pedagógicos que visassem a fazer das crianças telespectadores dotados de espírito crítico, e isto desde a mais tenra idade.
\end{abstract}

Para Gómez (2001), a despeito de ser comum entre os professores a crença de que a televisão não educa, mas que as crianças aprendem com ela, mesmo negando a legitimidade dessa mídia como condutora de um processo educativo, tal pensamento 
permite-nos inferir que há por parte dos professores o reconhecimento da ação mediadora da tevê na aprendizagem dos alunos.

Apesar de existirem algumas iniciativas no sentido de utilizar as mídias como recurso pedagógico nessa modalidade de ensino, uma educação com, para e por meio de mídias ainda é uma tarefa não assumida, ou pelo menos não assumida com a qualidade necessária pelos professores e outros profissionais da educação, postura perfeitamente compreensível, se considerarmos que, apesar de existir uma grande discussão a respeito da formação de professores no sentido de qualificar esses profissionais para contemplarem as necessidades formativas das novas demandas, como a educação midiática que reivindicamos, ainda hoje se opera uma formação tradicional que negligencia um processo educativo dessa ordem.

Desde bebês, as crianças consomem uma imensidade de experiências visuais, sonoras e táteis que sendo fontes de representação do mundo em que vivem, acabam tornando-se referenciais para compreendê-lo. Curiosamente, mesmo estando cientes de tal condição, "A linguagem audiovisual, muito presente no universo das crianças, não suscita atenção dos educadores comparativamente ao escrito e à comunicação verbal que são objeto de procedimentos privilegiados de aprendizagem". Essa indiligência docente em relação às possibilidades pedagógicas das produções audiovisuais deixa escapar momentos bastantes favoráveis ao jogo, à brincadeira e, ao aprendizado. (GONET, 2004, p. 53).

Segundo Fischer (2007, p. 295), há uma infinidade de argumentos plausíveis para que se desenvolva uma educação com, para e por meio de mídias na escola desde a Educação Infantil, pois além de as telas midiáticas serem caracterizadas em nosso tempo por uma extraordinária velocidade e instantaneidade, por muitas vezes incentivarem 0 consumo desenfreado e por legitimarem valores por vezes deturpados, nelas "[...] não só temos acesso a informações e imagens, mas ouvimos e lemos histórias transformadas em grandes feitos, marcados por uma adjetivação de excelência, onde tudo é "super", "extra", "mega"”. Dentre muitos exemplos de como isso ocorre, o autor enfoca "[...] o jovem jogador de futebol vindo da zona norte carioca torna-se um Ulisses brasileiro; a adolescente descoberta no meio rural gaúcho transmuda-se em modelo de grife e é batizada de deusa." (p. 296). Considerando esse quadro cotidianamente vivenciado, a compreensão da lógica desses discursos e a dinâmica da linguagem midiática que leva à sua construção, sem dúvida, devem ser objetos de estudo na escola, pois "[...] tais elementos fazem parte dos discursos de nossa época e são aprendidos pelas crianças desde que nascem, habitam suas vidas, participam da construção de suas subjetividades, transformam seus modos de aprender e de existir." (p. 296). 
Na opinião de Penteado (1991, 2002), há muitas implicações do consumo da programação da tevê na educação escolar das crianças, pois ao consumirem a programação da televisão e os produtos e serviços massivamente veiculados por conta dos interesses da Indústria Cultural:

Dadas as proporções da linguagem icônica e sonora, [...] a linguagem escrita (letreiros de filmes, rótulos e propaganda) fica reduzida, no texto televisivo, a insignificantes proporções. Embora já se saiba que as crianças em idade pré-escolar e que ainda não frequentam a escola são capazes de identificar algumas palavras, como por exemplo, Coca-cola, a partir do seu consumo televisivo, sabe-se também que o que se deu foi uma mera retenção da "imagem" da palavra através da exposição altamente repetitiva, e não o aprendizado de leitura do código escrito, que supõe muitas outras operações além da mera identificação da imagem da palavra (1991, p. 98).

Isso que nos mostra Penteado (1991) indica que a tevê exerce um imenso fascínio nas crianças e influencia também em seu processo educativo, pois essa mídia as atinge em seu ponto mais sensível, o olhar. Kehl (apud SOARES, 1996, p. 48) reforça essa indicação afirmando que:

\footnotetext{
O ser humano apreende a TV pelo olhar e o olhar é o primeiro aparato da apreensão libidinal do mundo; um aparelho psíquico que dá início às novas apreensões, até a construção da identidade pessoal (pela via das identificações), funcionando como antecipação das relações com o objeto. O olhar capta a imagem, antes mesmo que a palavra a nomeie.
}

Essa espécie de sedução pelo olhar que a mídia televisiva exerce sobre as crianças tem gerado reações bastante diversas no sentido da proteção da infância. Dentre essas, destacam-se iniciativas como as da ONG canadense TV-Turnoff Network, fundada em 1994, que desenvolve campanhas de mobilização social, como a Less TV, More Reading (Menos TV, Mais Leitura) e a TV-Turnoff Week (Semana da TV Desligada). Desde 1995, essas ações já mobilizaram mais de 20 milhões de pessoas em todo o mundo. No Brasil, o Instituto Alana criou a ONG "Desligue a TV" que tem dentre outros objetivos promover o debate sobre o excesso do uso da televisão nos lares brasileiros, refletindo sobretudo sobre o consumo infantil incentivado por esse meio. 


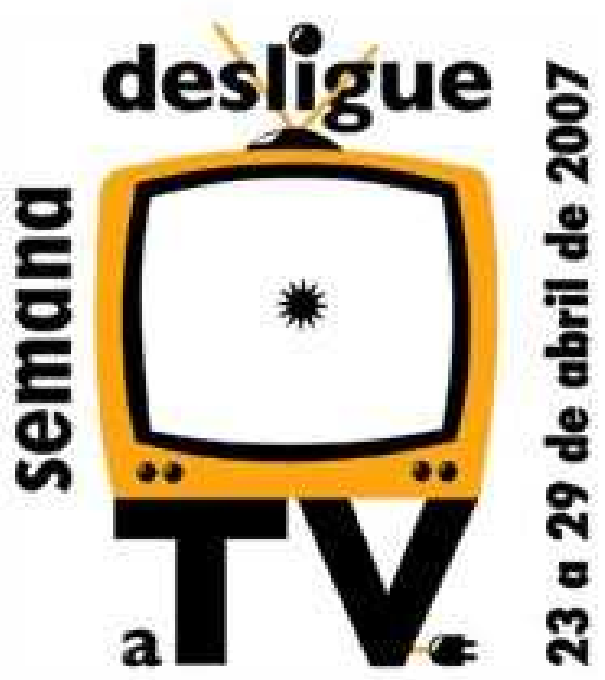

Figura 18: Imagem da Campanha Internacional Semana Desligue a TV 36 .

Importante dizer que, apesar da relevância de iniciativas dessa natureza, não será simplesmente privando as crianças de ver tevê, ou de ter acesso a qualquer outra mídia de apelo visual, que elas passarão a ser incólumes a essa característica da imagem potencializada pelas telas midiáticas.

Na perspectiva de Buckingham (2007, p. 245):

[...] o que precisamos discutir não é tanto se deveríamos proteger as crianças dos males que as mídias poderão infligir a elas, mas, ao contrário, como as mídias poderiam preparar as crianças mais efetivamente para as responsabilidades da cidadania adulta - ou mesmo habilitá-las a intervir nas decisões políticas que governam sua vida de criança (grifos do autor).

A carência de uma prática pedagógica que contemple uma educação midiática é facilmente compreensível quando levamos em consideração as concepções de infância que estão subjacentes às práticas pedagógicas dos professores que atuam na Educação Infantil. Pois, como refletem Micarello e Drago (2005, p. 133):

Estudos contemporâneos sobre a infância enfatizam que a criança é um sujeito social, que possui história e que, além disso, é produtora e reprodutora do meio no qual está inserida, atuando, portanto, como produtora de história e cultura. [...] Entretanto, um papel secundário relegado à criança - fundamentado numa imagem da criança como ser puro, sem consciência e sem voz nos processo sociais, políticos e econômicos, incapaz de opinar e de se expressar, imaturo para responsabilidades e sem direito de expor seus próprios desejos - ainda está presente nas práticas sociais e institucionais.

36 Disponível em: < http://www.desligueatv.org.br/>. Acesso em: 03/02/09. 
Essa realidade apontada por esses autores e cotidianamente observada em nossa prática docente, atuando em cursos de graduação (Pedagogia), pós-graduação e formação continuada de professores, é que nos leva a defender a importância de uma educação com, para e por meio de mídias, que tenha início já na Educação Infantil e que se desenvolva ao longo da formação escolar do sujeito, pois esta contribuirá significativamente para o desenvolvimento de habilidades que garantam ao indivíduo uma leitura sensível e reflexiva das imagens e do discurso dos meios de comunicação bem como a utilização dos recursos midiáticos na construção do conhecimento, base para uma sociedade mais participativa e democrática. "O ideal seria que os alunos não fossem apenas capazes de compreendê-los em profundidade (os meios), mas também de expressar-se por intermédio deles." (FERRÉS, 1996, p. 82).

As imagens e informações transmitidas pela tevê configuram e condicionam gradualmente as opiniões e os gostos das pessoas de uma maneira quase inconsciente. Uma hipótese do por que isso ocorre com as crianças, por exemplo, pode advir do fato de as crianças passarem mais tempo assistindo essa mídia do que fazendo qualquer outra atividade não escolar. Penteado (1991) afirma que "[...] esse fato já seria o suficiente para trazer a tevê e seus processos às considerações da escola" (p. 97).

Ao que nos parece, perante o mundo maravilhoso e dinâmico de imagens e sons da televisão e de outras mídias eletrônicas, como o computador e a internet, o ambiente escolar pode se tornar pouco interessante para as crianças. "Ao contrário da muitas vezes obstinada e triste realidade escolar, os filmes para crianças fornecem um espaço visual high tech, onde a aventura e prazer se encontram em um fantasioso mundo de possibilidade e numa esfera comercial de consumismo e comodismo." (GIROUX, 2004, p. 90).

Para Martín-Barbero (2000), os meios de comunicação proporcionaram à sociedade outros canais pelos quais circulam uma multiplicidade de saberes, consequentemente a escola deixou de ser o único espaço de acesso e legitimação do saber. Segundo esse autor, é também aí que reside o grande desafio da escola na contemporaneidade: manter-se atrativa e necessária aos educandos em uma sociedade que oferece múltiplos espaços de acesso ao saber.

De acordo com Fischer (1988), por um lado a criança gosta da tevê porque ela fala a sua linguagem, uma comunicação entrecortada, dinâmica, não linear, em mosaico. A criança é capaz de pular rapidamente de um assunto para outro, do mesmo modo que a ocorre na telinha. Um olhar mais atento permite verificar que, na telinha, passamos de um acontecimento trágico para um programa de humor, de um comercial de brinquedos para uma mensagem de um partido político.

Por outro lado, é importante destacar que em muitos casos esse gostar da telinha também é fruto da falta de opção de muitas crianças que, sendo obrigadas a permanecer 
enclausuradas no espaço de suas casas, muitas vezes mínimos e sem muitas opções de lazer e interação, acabam se limitando ao consumo da programação das mídias, principalmente da tevê (PONTES, 2005). Não podemos perder de vista a situação de muitas famílias que, vitimadas pela pobreza material, ainda fazem uso da velha "babá eletrônica", única companheira no cotidiano de várias crianças brasileiras.

Não é nenhum exagero quando Corsino (2005) chama a atenção para o fato de que um grande número de crianças que vive em áreas urbanas, de diferentes classes, que não frequentam a Educação Infantil, partilhando dessa maneira de outro tipo de exclusão:

Ficam dentro de casa, entre quatro paredes (sofrem toda a sorte de privação de um ambiente confinado, como a falta de contato com a natureza, movimentação contida etc.), com adultos ocupados em tarefas domésticas e trabalhos exercidos em casa, sem poder lhes dar atenção. Passam a maior parte do tempo sozinhas, sem crianças para partilhar as brincadeiras, assistem à televisão horas seguidas, os mesmos desenhos animados e acabam até tendo desejos semelhantes (p. 210).

O desafio apresentado à escola e aos educadores, e aqui incluímos a família também, é resumido por Kaplún (1999, p. 74) quando afirma que "[...] educar-se é envolverse em múltiplos fluxos comunicativos". Para o autor, quanto mais o professor proporcionar aos alunos situações que instiguem a trama das interações comunicacionais, mais educativa será sua prática pedagógica. Perante o exposto, a escola, inserida nessa outra realidade social, já não pode fugir à necessidade de uma educação midiática que, frente ao contexto ora vivenciado, legitima-se como uma responsabilidade social da escola.

Para Ferrés (1996), na experiência da televisão, os pais e educadores devem assumir o papel de mediadores, para ajudar seus filhos e alunos a compreender o que significa a experiência de ser telespectador e a interpretar com atenção o sentido dos programas. Trata-se de enriquecer a experiência de espectador, mas sem negá-la, de criar a possibilidade de uma leitura sensível e reflexiva das diferentes mídias, porém sem eliminar o prazer sensorial e emocional que as mídias audiovisuais proporcionam, especialmente às crianças.

Sobre os caminhos para atingir essa meta, indica Penteado (1991, p. 49): "É nos seus grupos que o indivíduo vai trabalhando as impressões, ideias, informações recebidas via TV; e é aí no embate de pontos de vistas discrepantes, no confronto de semelhantes visões e no encontro delas, que se vai apropriando da imagem que recebeu, a partir da qual elabora a sua imagem própria".

Os modus operandi estaria então na construção de saberes a partir da inter-relação das muitas informações acessibilizadas por meio das diferentes mídias, e não proibindo as crianças de consumirem um determinado meio de comunicação, como a tevê, a Internet e os videogames. Menosprezar ou até mesmo ridicularizar a programação que assistem, 
consomem, em nada contribui para a construção de um olhar mais sensível e reflexivo frente às mídias. Nas palavras de Lazar (1999, p. 98), "[...] poderíamos habituar as crianças desde a infância a assistir programas de qualidade. Mas para isso é necessário que os programas destinados às crianças sejam de qualidade. E nada nos permite supor que as crianças assistirão a esses programas e não outros". É preciso levar em conta os apelos dos mega grupos corporativos que, com suas máquinas multicoloridas, tornam a linha que separa ficção - realidade cada vez mais tênue; transformam a publicidade em necessidade; transformam todas as relações em relações mercantis, a exemplo do que ocorre na trama das novelas brasileiras.

Assim, pouco adianta os professores insistirem para que os pequenos pararem de consumir a programação das redes comerciais e que passem a consumir a programação das tevês educativas, quando nem mesmo os educadores assistem a esta programação, já que também eles sucumbem à programação massiva das redes comerciais de tevê e rádio. O enfrentamento desse problema surtirá efeito quando os professores abandonarem a estratégia falida da repressão e assumirem a condição de mediadores dos múltiplos fluxos de informação e comunicação que emergirem na sala de aula, inclusive aqueles que recorrentemente são alimentados pela programação televisiva. (GÓMEZ, 1997).

Outro fator que precisa ser levado em conta é que se as crianças consomem uma programação de baixa qualidade é porque também aprenderam isto, seja com outras crianças ou, como ocorre na maioria das vezes, com os próprios adultos. A formação de uma mentalidade sensível e reflexiva que assegure uma participação mais vivencial, sensível e crítica em relação ao consumo de mídia somente se dará quando desenvolvermos uma educação com, para e por meio de mídias nas escolas que garanta às crianças e jovens saberes para uma escolha consciente daquilo que querem ver na televisão. Ademais, vale atentar para o que considera Gómez (1997): "[...] o que as crianças aprendem fora da classe tem importância em sua aprendizagem formal escolar, motivo suficiente para tal vivência ter importância também em nossa prática (educativa escolar)." (p. 63).

Educar com, para e por meio de mídias constitui uma ação completamente diferente daquela que assiduamente encontramos em muitas escolas, nas quais, cientes da presença constante da tevê no cotidiano das crianças, os professores acabam desenvolvendo atividades rotineiras e reprodutivas, ou usando este meio apenas como uma ilustração do conteúdo previamente programado. Em outras palavras, o potencial pedagógico da televisão tem sido pouco explorado pelas escolas em tarefas que permitam ao aluno desenvolver um olhar sensível e reflexivo a respeito daquilo que ele vê diariamente na telinha dessa mídia. 
[...] enquanto o ensino discursa pelo âmbito do livro, o professor se sente forte, mas quando o mundo da imagem aparece, o professor perde o prumo, seu terreno se move, porque o aluno sabe muito mais e, a sobretudo, manejar muito melhor a linguagem da imagem do que o próprio professor. $E$, além disso, porque a imagem se deixa ler com a unilateralidade de códigos que a escola aplica ao texto escrito. (MARTIN-BARBERO, 1999, p. $29,30)$.

A respeito disso que denuncia Martín-Barbero (1999), Penteado (1991, 2002, 2003) afirma que não basta apenas a escola possibilitar o acesso a esses meios aos professores isto por si só não promove transformações significativas na prática pedagógica docente. Para superação dessa realidade, a autora assevera que é preciso contextualização, intenção pedagógica e planejamento, pois são esses elementos que possibilitarão explorar ao máximo o potencial pedagógico, educativo e riquíssimo da televisão.

Ao negligenciar a prática de uma educação midiática, Fischer (2007) alerta que as perdas são muitas, pois:

[...] estudar as imagens, os processos de produção de materiais audiovisuais, as formas de recepção e uso das informações, narrativas e interpelações de programas de televisão, filmes, vídeos, jogos eletrônicos, corresponderia, a meu ver, a práticas eminentemente pedagógicas e indispensáveis ao professor que atua nestes tempos. Isso porque há todo um trabalho de simbolização, no lugar daquele que imagina, planeja, produz e veicula filmes, novelas, telejornais, vídeos, assim como há um trabalho permanente de simbolização, no lugar daquele que se apropria do que vê ou ouve a partir das diferentes mídias. (p. 296).

Apesar de esses desencontros serem bastante recorrentes na prática pedagógica de muitos docentes, independente da esfera em que atuam - pública ou privada -, isto não quer dizer que hoje os professores sejam dispensáveis; pelo contrário: para dar conta dessa educação midiática eles continuam sendo personagens essenciais. Não mais como únicos detentores do saber, mas como mediadores da aprendizagem dos alunos. Aquele que educa no sentido de ensinar o educando a selecionar as informações relevantes para a construção de sua aprendizagem. (D’AMBRÓSIO, 2003).

$\mathrm{Na}$ condição de mediador da aprendizagem, o professor deve empenhar-se em colocar a cultura elaborada em diálogo e confronto com a cultura propagada pelas diferentes mídias. Nesse movimento dialético, os saberes construídos na escola ganham funcionalidade e relevância à medida que auxilia o aluno a "[...] decifrar contextualizar e questionar o imaginário da nossa realidade cotidiana e a entender e praticar suas várias linguagens." (GARRIDO, 2001, p. 126). 
Mediação pedagógica, neste exercício de pesquisa, é entendida como uma dimensão relacional - de interlocução - constitutiva do processo de aprendizagem. As relações que são travadas entre professores e alunos permitem construir e reconstruir o sentido de um conteúdo, um processo, abrindo desta forma espaço para novas relações do educando com os materiais de estudo, com o contexto sociocultural, com os professores, com os colegas, consigo mesmo e com o mundo em que vivem ${ }^{37}$.

Nessa perspectiva de desenvolver uma prática pedagógica mediadora, caracterizada dessa forma, a tevê possui um altíssimo potencial a ser explorado por esse outro professor de que carecemos:

Como educadores, é fundamental que se acompanhe a criança nessa
busca do conhecimento, nessa curiosidade viva e permanente diante do
mundo. Há uma infinidade de usos da TV num processo educacional.
Estudando como se faz TV, informando-se a respeito como os alunos
veem, os professores podem realizar ótimos debates, excelentes
encontros, podem estimular a busca de novas informações. E podem aos
poucos, compreender melhor a si mesmos, a sociedade e essa caixa
mágica que mistura sonhos, desejos e mentiras, refletindo um pedaço da
história que vivemos. (FISCHER, 1988, p. 61).

A questão que emerge quando consideramos essa realidade é o porquê de os professores da Educação Infantil e suas práticas ainda estarem tão distantes desta educação tão indispensável que é uma educação com, para e por meio de mídias na escola. Acreditamos que a resposta a tal pergunta tem a ver com a deficitária formação dos professores que atuam nessa modalidade de ensino. Pois, em pleno século XXI, a maioria dos cursos de formação de professores vem tratando com descaso e negligência aspectos cruciais da formação, como:

- O conceito cientificamente fundamentado de criança na contemporaneidade (ser biopsicossocial);

- O conhecimento sócio antropológico que possibilita uma melhor compreensão da complexidade da atual dinâmica social e da cultura contemporânea, que resultam nas diferentes infâncias que encontramos em nossas salas de aula;

- As implicações oriundas da ação das mídias na educação das crianças e na constituição das infâncias do nosso tempo.

Como bem lembra Fischer (1988, p. 61), é "[...] visível que também o professor precisa aprender a ver televisão, a analisar a TV a partir daquilo que ele gosta de ver, porque gosta, o que mais o prende na TV, o que a TV ensina, o que ele aprende com a TV". Esse deve ser o ponto de partida para a formação do professor como espectador crítico.

\footnotetext{
37 Conceito adaptado do glossário disponível no livro TV na escola e os Desafios de Hoje: tecnologias e educação: desafios e a escola, Módulo 1, $2^{\text {a }}$ edição.
} 
Vale enfatizar que, para lançarmos um olhar crítico sobre o mundo em que vivemos, é preciso antes de tudo conhecer esse mundo em seus muitos aspectos constitutivos.

Em conformidade com Fischer (1988), Gonet (2004, p. 51) adverte que o desenvolvimento de uma educação dessa natureza implica em um esforço de comunicação entre gerações e que, para isto, "[...] é preciso também considerar que o professor não está necessariamente bem colocado, bem formado, para abordar essas estas áreas novas num espírito construtivo". Para ser crítico é preciso antes conhecer, em toda a extensão da palavra. Quanto mais informações o professor tiver, mais terá condições de avaliar de forma crítica o mundo em que vive.

Uma análise mais cuidadosa dos currículos dos cursos de formação de professores e licenciatura nos leva a depreender que uma educação com, para e através dos meios de comunicação não é objeto de estudo da maioria deles. A exceção é o curso de Pedagogia, o qual a partir da década de 1990 passou a ter efetivamente um componente curricular que tenta suprir essa carência: Tecnologia Educacional ou Informática na Educação. Alguns, além desse componente curricular, apresentam também a disciplina Educação e Comunicação, mas é muito raro isto ocorrer.

A despeito da existência dessas disciplinas no curso de Pedagogia, consideramos pouco apropriado afirmar que habilidades para o uso pedagógico das mídias na prática docente são efetivamente construídas e praticadas pelos docentes. Um dos fatores que concorrem para isso é que comumente a atenção dessas disciplinas volta-se apenas para as tecnologias informáticas, desprezando as possibilidades pedagógicas que podem ser exploradas em outras mídias, como a tevê, por exemplo. Outro fator que contribui para o pouco aproveitamento dessas disciplinas é que elas costumam ocorrer de forma bem pontual: ou são extremamente teóricas, negligenciando aos professores em formação experiências práticas no exercício de uma pedagogia da comunicação midiática; ou são exclusivamente práticas, em geral realizadas em um laboratório de informática. Tanto em uma situação como em outra, fica patente a carência de um processo formativo propiciador de um diálogo entre teoria e prática, que proporcione procedimentos didáticos coerentes com a meta de uma educação com, para e por meio de mídias.

A superação desse problema consiste então no desenvolvimento de um processo de formação que, além de dotar o professor de saberes referentes ao conteúdo, permita estabelecer críticas e/ou manusear com habilidade sofisticadas tecnologias midiáticas. De acordo com Fischer (2007, p. 296), uma formação adequada deveria possibilitar ao docente "[...] apanhar cada produto midiático em sua concretude histórica, comunicacional, mercadológica, política, e também como material que é produzido e veiculado segundo um 
determinado aparato técnico que, por si mesmo, também produz efeitos em nós". A tevê é um bom exemplo disso.

De acordo com Libâneo (2006), a resolução de grande parte dos problemas que afligem a formação de professores não implica simplesmente em uma mera reformulação dos cursos de Pedagogia, responsável pela formação daqueles que irão atuar na primeira etapa da Educação Básica. Para ele, o caminho para uma formação mais adequada dos profissionais que atuarão na educação atual consiste em as instituições de ensino superior serem mais sensíveis às necessidades das demandas formativas que vêm da escola, sobretudo das escolas públicas, onde as carências são ainda maiores.

A carência de uma formação pedagógica que contemple as novas demandas escolares, como a educação midiática a que reivindicamos neste trabalho, torna-se ainda mais exacerbada se considerarmos aquela recebida pelos professores que atuam na Educação Infantil. Conjeturamos dessa maneira por sabermos que mesmo desempenhando uma atividade indispensável para o desenvolvimento de qualquer nação, historicamente, no que se refere ao Brasil, essa modalidade de ensino ficou a reboque de outros níveis de ensino, como o ensino fundamental e o ensino médio.

\footnotetext{
A formação do educador infantil permanece uma questão periférica e são vagas as referências e estudos especiais e exercícios informais na prática para aqueles que viriam a atuar com a criança de 0 a 6 anos. A exigência para a contratação de um profissional recorre a aptidões especiais como a dedicação à criança e a disponibilidade do profissional. (KISHIMOTO, 2001, p. 101).
}

A título do que havia ocorrido na Europa do século XVIII, onde surgiram as primeiras instituições de Educação Infantil com a função de cuidar dos filhos das operárias, que foram convocadas a suprir as demandas da Revolução Industrial; aqui no Brasil, apesar de estas instituições só despontarem no século XIX, os motivos que levaram a isto não foram diferentes. Com base nos estudos de Buckingham (2007, p. 22), verificamos que no contexto europeu as escolas foram criadas como espaço legítimo para crianças, assim essas foram recolhidas das ruas e fábricas, onde antes coabitavam com os adultos, e restringidas ao espaço escolar. Em decorrência disso: "[...] uma série de novas instituições e agências sociais buscaram supervisionar seu bem-estar, de acordo com um ideal doméstico bastante ligado à classe média, voltado assim para garantir a 'riqueza da nação'”.

O propósito de cuidar somado ao caráter filantrópico das primeiras instituições que despontaram em nosso país fizeram com que o único pré-requisito para desempenhar a função fosse, desde o início, dispor de tempo e "saber cuidar" de crianças. 
Somente no final dos anos 1980 é que esse cenário começou a tomar novos rumos. Foi a partir desse momento que o governo brasileiro passou a ser pressionado a assumir seu compromisso, sua responsabilidade conforme determinado na Constituição da República Federativa do Brasil de 1988:

Art. $6^{\circ}$ - São direitos sociais: a educação, a saúde, [...] a proteção à maternidade e à infância, a assistência aos desamparados, na forma desta Constituição".

Art. 208 O dever do Estado com a Educação será efetivado mediante garantia de: IV - atendimento em creche e pré-escola às crianças de zero a seis anos de idade;

Art. 211 - A União, os Estados, O Distrito Federal e os Municípios organizarão, em regime de colaboração, seus sistemas de ensino. II - Os Municípios atuarão, prioritariamente, no Ensino Fundamental e na Educação Infantil.

Art. 227 - É dever da família, da sociedade e do Estado assegurar à criança e ao adolescente, com absoluta prioridade, o direito à vida, à alimentação, à educação, ao lazer, à profissionalização, à cultura, à dignidade, ao respeito, à liberdade e à convivência familiar e comunitária, além de colocá-los a salvo de toda a forma de negligência, discriminação, exploração, violência, crueldade e opressão.

A Constituição de 1988 foi o primeiro de uma série de documentos que, em seu conjunto, legaram ao Brasil uma das legislações mais modernas em relação à infância. Além disso, asseguraram à criança na nação brasileira seu reconhecimento enquanto sujeito social de direitos. Dentre as contribuições de cada um desses documentos, os autores destacam que: a constituição de 88 garantiu a Educação Infantil como direito das crianças e das famílias; a LDBEN de 1996 asseverou a esta modalidade de ensino a condição de primeira etapa da educação básica; já o Plano Nacional de Educação de 2001 e o ECA de 1990 legitimaram os direitos legais das crianças e adolescentes. (MICARELLO; DRAGO, 2005).

Em consonância com isso, Pinazza (2007) afirma que na década de 1990, ao serem sancionados, esses documentos legais também deram maior visibilidade à Educação Infantil e, consequentemente, aos profissionais que atuam nessa modalidade de ensino, especialmente aqueles que desenvolvem atividades docentes.

Ao frisar os professores, afirma que foi somente a partir desse momento que eles, depois de quase um século, tiveram legalmente garantido um estatuto próprio. 
O reconhecimento da especificidade do trabalho com a criança de 0 a 6 anos, sobretudo, a partir das disposições da Constituição Federal de 1988; no estatuto da Criança e do Adolescente de 1990 e na Lei de Diretrizes e Bases da Educação Nacional (LDBEN) de 1996, reflete-se na concepção de formação e profissionalização de professores da educação infantil. (PINAZZA, 2007, p. 22).

Sobre a formação dos profissionais da Educação Infantil, Kishimoto (2001) afirma que a despeito de os documentos já sinalizarem a necessidade de os profissionais terem formação em nível médio ou superior, foi somente com a definição da Educação Infantil como primeira etapa da Educação Básica, legalizada pela Lei 9394/96 (LDBEN), que se passou a ter parâmetros de nível de formação adequada a ser exigida a estes profissionais.

\begin{abstract}
A formação de docentes para atuar na educação básica far-se-á em nível superior, em cursos de licenciatura, de graduação plena, em universidades e institutos superiores de educação, admitida como formação mínima para o exercício do magistério na Educação Infantil e nas quatro primeiras séries do Ensino Fundamental, a oferecida em nível médio, na modalidade Normal (Lei Federal n. 9.394/96, artigo 62) (grifo nosso).
\end{abstract}

Mais que legitimar os cursos de magistério superior como formação mínima para o exercício da docência na Educação Infantil, Kishimoto (2001) chama a atenção para o fato de também nessa lei termos estipulados os princípios básicos que deveriam nortear a formação dos profissionais da Educação Básica:

\begin{abstract}
A formação de profissionais da educação, de modo a atender aos objetivos dos diferentes níveis e modalidades de ensino e às características de cada fase do desenvolvimento do educando, terá como fundamentos:

I - a associação entre teorias e práticas, inclusive mediante a capacitação em serviço;

II - aproveitamento da formação e experiências anteriores em instituições de ensino e outras atividades" (Lei Federal n. 9.394/96, artigo Art. 61).
\end{abstract}

A LDB instituiu que o período compreendido entre 1997 e 2007 seria considerado a década da educação. Assim, ao final desse período, somente seriam admitidos para a educação básica, profissionais habilitados em nível superior ou formados por treinamento em serviço. Porém, o Decreto no 3.554, de 7 de agosto de 2000, revogou essa indicação. Assim, passou-se a ter como referência: "§ 2 A formação em nível superior de professores para a atuação multidisciplinar, destinada ao magistério na educação infantil e nos anos iniciais do ensino fundamental, far-se-á, preferencialmente, em cursos normais superiores".

Mesmo com a desobrigação da formação superior como requisito indispensável para docência na Educação Infantil, é inconteste que esses documentos legitimaram uma série de melhorias à formação dos professores desta modalidade de ensino. A despeito disso, 
poucas foram as mudanças substanciais e transformadoras na formação dos professores dessa modalidade de ensino no nosso país. Pois, para além do cuidar, uma verificação da prática pedagógica de muitos professores que atuam na Educação Infantil atual mostra ora uma ênfase nos aspectos assistenciais, ora no caráter pedagógico, quase sempre restrito à mera reprodução de saberes prontos.

Frente a tal situação, consideramos bastantes pertinentes as indagações de Micarello; Drago (2005, p. 134): "[...] onde fica a criança como sujeito social? Sua história, seu saber, sua identidade, que espaço ocupam nas políticas públicas voltadas à infância? Que espaço tem ocupado a criança como sujeito histórico-cultural nas políticas de formação dos professores de educação infantil?".

Ainda no que se refere aos problemas na formação dos professores para atuação nessa modalidade de ensino, Cerisara (2002) alerta que, com a promulgação da Lei de Diretrizes e Bases da Educação em 1996, tivemos a emergência de dois problemas. Um relativo à qualidade da "formação" e outro decorrente das cobranças geradas pela nova lei. Nas palavras dessa autora:

[...] pouco ou quase nada acerca da especificidade da educação infantil têm sido contemplado (nos cursos de formação), prevalecendo uma concepção de trabalho que transporta de cima para baixo os chamados conteúdos escolares acabando por submeter as creches e pré-escolas a uma configuração tipicamente escolar. Além disso, o governo delega a essas professoras a responsabilidade por sua formação, sem assumir como sua a tarefa de fornecer as condições objetivas para que elas se profissionalizem. (p. 05).

Essa situação acaba convertendo-se em angústias para o professor, pois se de um lado há uma série de cobranças no que concerne à formação de professores, pouco é oferecido pelo poder público no sentido de motivar esse profissional a investir em sua formação profissional. No Brasil, mesmo somando 15\% dos docentes da Educação Básica, os profissionais que atuam na Educação Infantil são os que recebem os menores salários e têm a pior formação inicial. Desse montante, 54,3\% têm formação apenas no Ensino Médio; $42,9 \%$ têm formação no ensino superior ou pós-graduação; e 2,8\% ainda estão na condição de leigos. Quanto aos salários, enquanto um professor de Ensino Médio ganha, em média, $R \$ 1.390,00$ por jornada e um de Ensino Fundamental recebe $R \$ 873,00$, o professor de Educação Infantil limita-se a receber em média apenas $\mathrm{R} \$ 661,00{ }^{38}$

Mesmo com essas condições pouco animadoras, incontáveis desafios são paulatinamente postos ao trabalho docente. Atualmente, a vivência em uma sociedade cada

38 Segundo dados da pesquisa Professores do Brasil: impasses e desafios realizada pelas professoras Bernadete Gatti e Elba de Sá Barreto. Esses resultados foram divulgados pela Organização das Nações Unidas para a Educação, a Ciência e a Cultura - UNESCO em outubro de 2009 - (Revista Nova Escola, Nov., 2009). 
vez mais complexa, faz com que surjam "[...] novas perspectivas em relação ao ensinar/aprender que consideram que há uma construção de significações (afetos e conhecimentos) pela criança desde o nascimento, mediada por parceiros adultos mais experientes" (KISHIMOTO, 2001, p. 104), o que implica em uma formação de mais qualidade ainda.

No contexto sociocultural da escola, Libâneo (2006, p. 170) elenca uma série de fatores que hoje atingem diretamente o cotidiano dessa instituição, os quais precisam ser trabalhados no processo de formação inicial e continuada do professor. Dentre esses, convém destacar:

[...] a intensificação da urbanização que [...] provoca a ampliação da diversidade social e cultural dentro da escola; o impacto dos meios de comunicação na vida escolar e na aprendizagem dos alunos; mudanças nos processos internos de aprendizagem dos alunos; fragilidade das formas de organização e gestão da escola em meio a mudanças abruptas na organização curricular [...]; dificuldades do professorado em adequar-se a mudanças, acentuadas com a falta de domínio de conteúdos e metodologias das disciplinas; perplexidade diante de problemas ligados à violência, ao uso de drogas, à sexualidade precoce dos alunos, ao controle da disciplina em classe. (grifo nosso).

Registre-se aqui que se o que está em questão é garantir "o desenvolvimento integral da criança até seis anos de idade, em seus aspectos físico, psicológico, intelectual e social, complementando a ação da família e da comunidade," 39 (Grifo nosso), considerando as palavras de Libâneo (2006), uma ação educativa que assegure às crianças a participação de seu processo de ensino-aprendizagem, que as conceba como sujeitos sociais agentes e que proporcione um olhar sensível e reflexivo sobre as mídias, são medidas urgentes e necessárias.

Partindo disso, para dar conta da realidade experienciada pelas crianças do nosso tempo, a Educação Infantil, com suas políticas e práticas pedagógicas, precisa assumir um papel "[...] sistematizado nas normativas atuais que traz consigo não apenas uma nova visão de criança, mas também uma nova concepção de profissional” (KISHIMOTO, 2001, p. 104). Pois, o que espera dos profissionais que vão atuar nessa modalidade é que "[...] seja capaz de organizar o espaço, o tempo, os materiais, os agrupamentos de crianças e propor atividades que promovam as interações de modo desafiador." (MACHADO apud KISHIMOTO, 2001, p. 105).

Uma condição indispensável para se suprir as expectativas da sociedade tanto em relação à qualidade da Educação Infantil quanto da formação dos professores que atuam

39 LDBEN (9394/96), na Seção II, no título Da Educação Infantil, especificamente no Artigo 29, a respeito do que compete à educação infantil. 
neste nível de ensino é que além da formação inicial e de melhores condições profissionais e de trabalho, aos professores seja também garantido um constante processo de formação continuada. Pois, é incontestável que "[...] o planejamento, a organização, a execução, o acompanhamento, a avaliação do trabalho e a atenção individual às crianças exigem profissionais [...] com sensibilidade, formação inicial consistente e em constante atualização e reflexão a respeito da sua prática." (CORSINO, 2005, p. 215).

Para Kramer (2002), dentre as muitas dimensões que devem constituir a formação dos profissionais de Educação Infantil, uma boa formação cultural faz-se imprescindível. Segundo ela, por meio das diversas manifestações artísticas, como a literatura, a música, o cinema, o teatro, a pintura, as artes plásticas em geral, as leituras, o professor deve oportunizar às crianças experiências que potencializem a essência humana das crianças, levando-as além da dimensão didática, a refletirem sobre os sentidos da vida, o configuração do cotidiano vivenciado e a ressignificação desse.

Apesar disso que adverte Kramer (2002), o longo dos anos, o imaginário foi visto com descrédito por ser entendido como representação acrítica da realidade, sobretudo por ser constituir por "[...] representações contaminadas pelos desejos e necessidades ou pelas representações e crenças dos indivíduos ou grupos." (GARRIDO, 2001, p. 127).

Essa condição herdada de nossa tradição racionalista tem seus impactos diretos no espaço escolar que, conforme Garrido (2001, p. 127), "[...] não tem trabalhado o imaginário. Privilegiando a aprendizagem das habilidades intelectuais e dos conteúdos.", desprezando assim as possibilidades e as potencialidades pedagógicas dele. Isso explica, por exemplo, o porquê de muitos professores ainda conceberem as artes, a música, as narrativas de ficção, a poesia, as literaturas etc., apenas como formas/mecanismos proporcionadores de prazer, de diversão. O que legitima também a negação do potencial dessas manifestações para o processo de construção do conhecimento.

\footnotetext{
As concepções de valor moral e as explicações que as crianças dão para a realidade que as circunda também não são trazidas para a sala de aula. Produtos de uma visão intuitiva e ingênua, são ignoradas pelo professor, a quem cabe substituí-las por valores éticos abstratos e por conhecimentos científicos. (GARRIDO, 2001, p. 128).
}

De certa maneira, é também com certo menosprezo que os conteúdos que as crianças consomem de mídias como a televisiva são concebidos pelos professores. Deixa-se escapar a inescapável condição de consumidor de mídias dos alunos, bem como a relevância que a escola tem em ensina-lo a aprender a olhar a programação televisiva de maneira mais sensível e reflexivo, condição indispensável para tornar-se um leitor crítico do mundo em que está inserido. 
É também a negação da força das representações que emergem em sala de aula, do poder comunicacional e criador que têm e das contribuições que podem trazer para o processo de ensino aprendizagem que nos ajudam a compreender o que faz com que:

Quando a criança fala dos seus programas de TV preferidos, quando fala de seus personagens prediletos ou daqueles que mais a amedrontam ou desgostam, fala de suas inquietações, de seus desejos, de seus temores, de seus preconceitos, de seus sonhos e daquilo que a oprime. Fala de si mesma e de sua vida, de como se sente em seu ambiente familiar, junto aos colegas e amigos. Seu interior é projeto nesses objetos, que se transformam em representações de seu mundo interior. (GARRIDO, 2001, p. 128).

Essa preocupação com uma melhor formação cultural do professor como condição indispensável para uma prática pedagógica mais coerente com as demandas emergentes das escolas, em especial as públicas, onde geralmente as carências são maiores, também encontra ressonância na obra de Fischer (2007, p. 298), para quem muitas são as possibilidades e os benefícios quando o professor é dotado de uma formação nesse sentido:

[...] ampliar as possibilidades de estabelecer relação, de ligar um trecho de Chico Buarque e uma cena de Pedro Almodóvar, por exemplo; ou versos de Cecília Meireles a uma cena de desenho animado fora da grande mídia; perguntar-se a respeito o nome da apresentadora virtual Eva Byte a respeito da tecnologia digital que não abre mão da "realidade"; realizar pesquisa de audiência, feita por alunos adolescentes, com crianças da mesma escola que eles frequentam, sobre o que veem na televisão todos os dias; produzir um novo roteiro para os mesmos personagens de uma telenovela, quem sabe apoiando-se na leitura de um conto de Guimarães Rosa ou Machado de Assis. Por que não? As possibilidades são infinitas. (p. 298).

Ao afirmar que existem múltiplas possibilidades de trabalho quando se detém um repertório cultural amplo, Fischer (2007, p. 298) também alerta ser factível o desenvolvimento de um saber-fazer resultante da ousadia dos pares que atuam no processo educativo, principalmente do professor. "A ampliação do repertório pode configurar-se inclusive como o exercício de outras formas de recepção e apropriação dos próprios materiais cotidianos, presentes na mídia e fartamente consumidos por alunos e professores." $\mathrm{Na}$ sociedade midiática na qual estamos inseridos, caminhar nessa perspectiva implica em um exaustivo e rico exercício da percepção do cotidiano, especialmente aquele retratado nas telas das mídias, fontes inesgotáveis de informações oportunizadoras de novos conhecimentos.

Um olhar mais atento a respeito dos processos formativos na atualidade permite perceber a emergência de alguns arranjos curriculares com iniciativas nessa perspectiva indicada por Kramer (2002) e Fischer (2007). Quanto ao ponto de partida para isso, apesar de não haver um consenso, acreditamos que deveria sempre ser considerado o fato de que 
o professor, antes de assumir a condição de profissional da educação, é um ser humano, uma pessoa, um cidadão que tem seus conceitos, suas teorias, suas ideias, suas crenças, seus sentimentos. A respeito dessa prerrogativa, adverte Kishimoto (2001, p. 106): "A identidade profissional está assim associada à identidade pessoal. Dessa forma, crenças, valores, projetos de vida são elementos importantes quando tratamos de formação, uma vez que se exprimem na qualidade do trabalho desses profissionais".

Quando o que está em pauta são os saberes teóricos e metodológicos relativos ao uso das mídias em sala de aula com uma intenção pedagógica, como defendemos aqui neste trabalho, deve-se questionar antes qual a percepção que esses profissionais têm da mídia na sua própria experiência de vida na educação das crianças. Desvelar quais as concepções deles em relação aos meios de comunicação, especialmente a tevê na aprendizagem das crianças.

\begin{abstract}
O ensino é uma prática social, não só porque se concretiza na interacção entre professores e alunos, mas também porque estes actores reflectem a cultura e contextos sociais a que pertencem. A intervenção pedagógica do professor é influenciada pelo modo como pensa e como age nas diversas facetas da sua vida. (LANGFORD apud SACRISTÁN, 1995, p. 66).
\end{abstract}

Outro ponto que precisa ser considerado em relação aos profissionais da educação é que estes também se constituem profissionais no dia a dia de sua prática; afinal, como bem afirmou Tardif (2002, p. 57), "[...] se uma pessoa ensina durante 30 anos, ela não faz simplesmente alguma coisa, ela faz também alguma coisa de si: sua identidade carrega marcas de sua própria atividade, e uma boa parte de sua existência é caracterizada por sua atuação profissional". Como consequência, esse profissional adquire seu ethos, suas próprias ideias, suas funções, seus interesses.

Para Tardif (2002), diferente do que se imagina, não é exclusivamente na universidade que o professor aprende tudo o que precisa para exercer sua prática docente; sua prática resulta em grande parte de saberes construídos a partir de fontes bastante diversificadas, não apenas daqueles conhecimentos construídos no processo de formação inicial, nos espaços da academia:

Ao longo de sua história de vida pessoal e escolar, supõe-se que o futuro professor interioriza certo número de conhecimentos, de competências, de crenças, de valores, etc., os quais estruturam sua personalidade e suas relações com os outros (especialmente com as crianças) e são reatualizados e reutilizados, de maneira não reflexiva, mas com grande convicção, na prática de seu ofício. (TARDIF, 2002, p. 72). 
Assim constituídos, pensamos ser bastante plausível que para muitos professores a tevê não represente uma aliada de sua atividade docente - já que, em sua prática diária, figure apenas como um meio de lazer. Porém, como condenar tal postura se não houver uma formação (inicial ou continuada) que explore as possibilidades pedagógicas dessa e de outras mídias audiovisuais?

Nesse contexto, em que de um lado as crianças consomem excessivamente as programações das diferentes mídias e que de outro os professores dão pouca atenção para a ação socializadora desses meios, as tecnologias midiáticas representam um desafio cultural para a escola, pois evidenciam a cisão existente entre a cultura com base na qual os professores ensinam e aquela outra com a qual os alunos embasam sua aprendizagem. (MARTÍN-BARBERO, 2003).

É certo que o enfrentamento de tal problema deveria ter início com reformas nas políticas de formação inicial de professores. Porém, enquanto não encontramos vontade política para isso, estamos convictos de que é preciso certa dose de ousadia por parte da escola e seus docentes. Dentre as possibilidades, estão aí os programas e projetos de formação continuada em serviço, muitas vezes, desenvolvidos pelos próprios profissionais que atuam na instituição, em grupos de estudos, comunidades de aprendizagem, por meio da leitura de textos provenientes de pesquisas acadêmicas, livros que abordam a temática, vídeos educativos, filme, pesquisas em sites da Internet, socialização de projetos desenvolvidos com e pelos alunos da escola etc.

É preciso o desenvolvimento de uma formação ampla que garanta ao professor de Educação Infantil conhecimentos (teóricos e práticos) a respeito do momento sócio-histórico em que vivemos: um mundo complexo, contraditório e em constante mutação. (KISHIMOTO, 2001). Isso poderia concorrer para a ampliação do olhar do professor até que haja um entendimento de que a tevê também pode colaborar, e muito, para o desenvolvimento das crianças, tanto para o seu lazer saudável como para o desenvolvimento de um olhar vivencial, sensível e reflexivo a respeito do mundo que experienciam.

Seguindo essa linha de raciocínio, Singer e Singer (2007, p. 92) defendem que, à medida que o consumo da programação televisiva é somado com práticas de leitura, momentos de discussão e debate familiar, currículos escolares compromissados com o pensamento crítico, a tevê passa a representar um poderoso mecanismo de enriquecer a experiência de aprender, já que oferece-nos a possibilidade de observar o mundo como um mosaico multifacetado, passível de múltiplas possibilidades de leitura.

O entrecruzamento das indicações até então apresentadas permitem-nos depreender que tevê pode assumir duas funções na formação cultural dos indivíduos: uma 
primeira que tem a ver com uma ação deformativa (responsável pela divulgação e inculcação de ideologias - dominantes - para/na consciência dos espectadores); e uma segunda que tem uma ação formativa, que consiste no uso deste meio de comunicação para divulgação de informações e de esclarecimentos potencializadores da construção de conhecimentos. (ADORNO, 2000).

No Brasil, mesmo sendo uma concessão pública, o compromisso primeiro da TV aberta comercial, dentre os legalmente definidos - informar, entreter e educar - não é educar, mas sim entreter; o que mais uma vez justifica a necessidade e relevância de uma mediação pedagógica desenvolvida por parte dos professores, pois, como assevera Gómez (2001, p. 63), “Toda la televisión, todas las televisiones 'educan' aunque no se lo propongan".

A importância dos professores reside também em serem estes os profissionais que cotidianamente atuam com as crianças no trabalho com a construção de conhecimentos, conforme afirma Giroux (2004, p. 105), "[...] não pode haver pedagogia cultural sem práticas culturais que explorem as possibilidades de diferentes formas de arte popular que revelem 0 talento dos alunos.". Em outras palavras, instigá-los a exercitar as muitas possibilidades de ler e refletir sobre o cotidiano além do que veem nas telas das mídias. "[...] estudantes não deveriam meramente analisar a representação da cultura popular transmitida pela mídia eletrônica - devem também estar aptos a dominar as habilidades e tecnologia para produzila. Isso significa fazer vídeos, músicas e outras formas de produção cultural." (p. 105).

Para isso, as escolas de Educação Infantil devem constituir-se como espaços de respeito e valorização da criança pequena. Espaços onde seja assegurada a expressão de suas formas de pensar, onde ela "[...] possa sentir e se expressar livremente, um lugar de convivência, de múltiplas interações e de abertura para o mundo, em que tenha acesso a diversas produções culturais, espaço de humanização e contribuição para justiça social e para a igualdade." (CORSINO, 2005, p. 216).

A construção de uma escola e de uma prática pedagógica dessa natureza implica no desenvolvimento de outras formas de socialização e participação diferentes daquelas geralmente encontradas nos espaços educacionais, marcadas por práticas meramente reprodutivas, diretivas que estão longe de conceber a criança como ser social, agente, ativo capaz não apenas de consumir as culturas dos adultos, mas também de transformá-las, de ressignificá-las e produzir as suas próprias culturas, as culturas infantis.

O contexto social, político, econômico e cultural no qual as infâncias contemporâneas são vivenciadas também requerem da escola outras formas de socialização do mundo. Isso porque as crianças, hoje, dispõem de outros espaços, meios e formas de acesso a 
informações e saberes que antes estavam restritos ao espaço escolar. Na sociedade atual, as crianças, em sua maioria, vivenciam processos de socialização cada vez mais diversificados, o que consequentemente colabora para que precocemente elas dependam, cada vez menos, de uma idade adequada, ou do auxílio dos pais ou mesmo da escola, para receberem informações e assim formarem suas opiniões a respeito dos mais diversos assuntos.

Conforme Lazar (1999), esse processo de diversificação das formas de socialização na infância foi impulsionado principalmente pela tevê. Segundo essa pesquisadora, a tevê oportuniza, nos seus múltiplos canais, facilmente acessíveis via controle remoto, uma quantidade infinita de informações que, por vezes, acabam vindo de encontro àquilo que aprenderam no seu meio familiar e/ou escolar.

Ao nos referirmos à necessidade de outras formas de socialização, que concorram para uma participação social mais ativa da criança, à luz dos estudos de Lazar (1999, p. 100), concordamos que esta deve se constituir em "[...] processo social pelo qual os indivíduos aprendem e interiorizam valores, crenças, conhecimentos, normas da sociedade em que vivem. [...] trata-se do processo graças ao qual o indivíduo se torna membro do seu grupo". Assim, para além das rotinas rotineiras que geralmente caracterizam as atividades escolares infantis, nas quais, muitas vezes, as crianças são concebidas como meras coadjuvantes, o processo de socialização o qual pensamos ser o ideal deve concebê-las como atores sociais e sujeitos agentes. Isso ocorre em virtude disso se caracterizar como um "[...] processo complexo e dinâmico que integra a influência de todos os presentes no meio ambiente e exige a participação ativa da criança." (BELLONI, 2007, p. 58).

Uma prática pedagógica pautada em um processo de educação escolar, como apresentado anteriormente por Lazar (1999) e Belloni (2007) oferecerá à criança uma leitura mais sensível, reflexiva e plural do grupo social, da sociedade, do mundo no qual ela está inserida. Sendo respeitada, garantida e potencializada sua condição de sujeito agente e ativo do processo, a criança também terá a oportunidade de olhar as mensagens oriundas das mídias de forma mais atenta.

Se é bem verdade que as mídias não substituem a intersubjetividade das crianças, sua criatividade ou autonomia, é preciso, porém, não esquecer que, no mínimo, estas máquinas maravilhosas fornecem conteúdos (imagens, símbolos, valores, modelos, representações) de que as crianças se apropriam e que elas reelaboram, criando suas culturas de pares, contribuindo, assim, para a reprodução da cultura de suas sociedades (BELLONI, 2007, p. 61). 
A escola de Educação Infantil, empenhada em promover processos de socialização potencializadores de práticas educativas cidadãs, poderá explorar as múltiplas possibilidades de socialização facultadas pela tevê que, conforme Girardello (1998, p. 162), em si não representam nenhum mal às crianças. Segundo essa pesquisadora, se essa mídia tem algum efeito positivo ou negativo no desenvolvimento das crianças, isto é decorrente "[...] de seus conteúdos e linguagens, do contexto da recepção e da qualidade geral da vida da criança - física, afetiva e poética - não podendo ser isolados dos demais processos socioculturais". Isso reafirma a necessidade de uma mediação pedagógica que possibilite um olhar sensível, vivencial e reflexivo sobre esse meio que, diariamente, representa o mundo e sua diversidade.

A importância da ação mediadora do professor também se justifica devido à íntima relação que muitos programas de televisão, voltados para crianças, têm com produtos e serviços alardeados por eles, tanto nos intervalos comerciais como no decorrer do próprio programa (merchandising). O agravante dessa condição cotidianamente observada na tevê (aberta e a cabo) é que os brinquedos, os acessórios, os games etc., tematicamente relacionados aos programas televisivos, estimulam acima de tudo a imaginação imitativa das crianças, o que acaba inibindo a imaginação criativa, que é um dos principais constituintes das culturas infantis (SINGER e SINGER, 2007, p. 80). Seguindo essa linha de raciocínio, pode-se deduzir que a mediação pedagógica faz-se imprescindível para o desenvolvimento da criatividade da criança que passa boa parte de sua infância diante da tela da tevê.

Ainda com Singer e Singer (2007, p. 93), aprendemos que "[...] a televisão, se usada com moderação, pode proporcionar-nos experiências que têm a possibilidade de inspirar nossa vida de fantasias e de imaginação para elevarmo-nos para além do aqui e agora". Por tanto, atuando na condição de mediador, diante de um desenho animado não comercial, por exemplo, o professor pode assegurar condições para que a criança crie personagens originais, use símbolos imaginários, invente sentimentos, diálogos e histórias que extrapolem as fronteiras, os limites da narrativa observada na telinha da televisão.

Podemos listar incontáveis benefícios oriundos de uma prática pedagógica dessa natureza, mediadora e compromissada com uma Pedagogia da Comunicação favorável a uma educação com, para e por meio de mídias:

[...] ajudar as crianças a aprenderem a usar a mídia como um instrumento para o seu próprio desenvolvimento, a serem usuários críticos e inteligentes dos vários meios de comunicação [...] é o melhor investimento. Elas precisam explorar as melhores possibilidades que a mídia pode oferecer, ao mesmo tempo em que também se protegem dos efeitos negativos ou potencialmente prejudiciais, simplesmente aprendendo a ser seletivas e 
conscientes e a 'ler' todas as formas de mídia. (ANGELES-BAUTISTA, 2002, p. 312).

Para Gómez (1997, 2009) e outros pesquisadores como Martin-Barbero (2001), Fischer (2007), Citelli (2000a), Soares (1996), Penteado (1999, 2002), Ferrés (1996), Belloni (2007), Buckingham (2007), Girardello (2003), dentre outros, é na qualidade da mediação pedagógica que reside a possibilidade de se construir efetivamente uma educação midiática compromissada com a cidadania e a efetiva participação social dos indivíduos.

\begin{abstract}
É preciso exercer explicitamente uma mediação que oriente a aprendizagem dos estudantes fora da aula, que permita recontextualizá-la, sancioná-la sob diversos critérios éticos e sociais, permitindo aproveitar o que de positivo oferecem os MCM, capitalizando para a escola a informação e as demais possibilidades que esses meios trazem. (GÓMEZ, 1997, p. 63).
\end{abstract}

A participação das crianças nos seus contextos diários tem pela frente grandes obstáculos a serem suplantados. Um deles, talvez o mais importante, é a necessidade de recuperação investigativa do professor sobre a vivência de sua própria infância, seus desejos, brincadeiras, jogos, significações atribuídas aos fatos, suas relações com pares e adultos, suas descobertas e suas "verdades" infantis.

A comparação dessa experiência vicária infantil dos docentes com a infância que seus alunos vivenciam hoje, e a reflexão sobre o papel da escola e de sua relação pedagógica com as infâncias atuais, são essenciais para a percepção das mudanças ocorridas no decorrer dos tempos entre estas duas gerações, e para transformações nas práticas da Educação Infantil. Tal exercício, se praticado desde a formação inicial, abriria caminhos para outras concepções de infâncias mais abrangentes, para uma compreensão mais apropriada da sociedade complexa vivenciada, e das novas demandas sociais que exigem uma formação escolar das crianças mais ajustada às necessidades emergentes do mundo atual.

Novas concepções essas que se constroem na intracomunicação do professor consigo mesmo; na intercomunicação do professor com seus pares e seus alunos; na transcomunicação do professor com os "múltiplos e diferentes mundos" representados pelas mídias e influenciadores da sociedade atual. Enfim, é na participação direta com e de seus alunos que o processo de ensino-aprendizagem se realizará, que a experiência da criança com o exercício da cidadania se efetivará, desde a escola de Educação Infantil.

Reivindicar o direito a uma participação mais efetiva da criança no espaço e nas práticas pedagógicas escolares não é nenhuma novidade em um momento em que diversas 
dimensões do discurso pedagógico têm exaustivamente mostrado seu descontentamento em relação a isto, porém, conforme denuncia Quinteiro (2005), este desrespeito à criança, seu silenciamento e não participação na sociedade atual resulta, sobretudo, das culturas escolares ora vigentes. Nas palavras dessa pesquisadora: "[...] a tomada de decisões por parte dos estudantes no nível das políticas educacionais ou no nível da organização pedagógica, não tem apoio explícito, tampouco, encontra-se contemplada na cultura da escola." (p. 02). O que leva a isso pode ser compreendido sem dificuldade quando indagamos sobre as concepções de infância e de criança predominantes entre os adultos que atuam no espaço escolar: crianças são seres incompletos, imaturos, não têm juízo, não têm condições de ajudar a decidir coisa alguma.

Subjacente a essa cultura que execra a voz ativa das crianças, subsiste a crença de que "As crianças não são adultos, portanto não podem ter acesso às coisas que os adultos definem como 'suas' e que acreditam serem os únicos capazes de compreender e controlar. [...] é negado às crianças o direito de autodeterminação." (BUCKINGHAM, 2007, p. 29). Dessa maneira, a concepção de infância que ao longo dos anos vem se perpetuando é caracterizada essencialmente pela falta, pela negação, "[...] atua nesse sentido como supressora de poderes das crianças. Assim, nos diferentes lugares em que convivem, e isto inclui o espaço escolar e os ambientes de mídia, os interesses da criança somente são levados em conta e talvez respeitados quando um adulto argumenta em seu nome.

Ao ser negada a participação sociocultural e ativa da criança, nega-se também a sua condição de cidadão, o seu direito de exercício da cidadania. A respeito dessa situação, considera Buckingham (2007, p. 244) que:

Mais uma vez, lidamos aqui com uma área da vida "adulta" da qual as crianças têm sido largamente excluídas. [...] também têm sido impedidas de se envolver nas decisões políticas que influenciam áreas centrais na sua vida. As políticas que lhe dizem respeito diretamente - em áreas como educação, bem-estar familiar e ofertas de lazer - são geralmente traçadas sem grandes esforços sem consultar ou registrar a visão das crianças. De modo geral, as políticas são conduzidas sobre as cabeças delas. É como se a maturidade política só começasse quando a infância chegasse ao seu final, em termos jurídicos ou biológicos. (p. 244).

Em uma sociedade em que os fluxos de informação e comunicação tornam o cotidiano cada vez mais complexo e dinâmico, garantir a participação direta das crianças nas tomadas de decisão coletivas, especialmente quando estas as envolvem diretamente, acima de tudo, implica em garantir os primeiros passos no exercício da cidadania, já na infância.

Foi partindo desse princípio que em seus estudos Bernstein (1996) reivindicou a ampliação dos direitos da criança na escola, pois, além do direito à realização pessoal 
(individual - confiança), por meio do qual realizam a compreensão sensível, reflexiva e cognitiva do mundo e descobrem novas possibilidades; o direito à inclusão social, intelectual, cultural e social (interativo - autonomia), que permite a cada criança ser autônoma no interior da respectiva comunidade, sendo nela aceita e acolhida. Esse autor reivindica um terceiro direito que deve ser garantido à criança, o direito à participação na prática (social - prática cívica) e nas decisões que envolvem uma coletividade.

Para Quinteiro (2002), esse silenciamento das vozes infantis é uma realidade observada não apenas nas escolas, onde em nome das relações pedagógicas culturalmente estabelecidas a participação da criança é didatizada e banalizada. A pesquisa voltada a compreender a infância e as culturas infantis também sofre influência dessa cultura que nega aos pequenos o direito à voz. Isso é tão latente que mesmo na atualidade, quando desponta uma quantidade de estudos a respeito das culturas infantis, muito ainda se ignora a respeito delas porque "[...] pouco se conhece [...] porque pouco se ouve e pouco se pergunta às crianças [...]. Há ainda resistência em aceitar o testemunho infantil como fonte confiável e respeitável". (p. 21). Consequentemente, tanto no cotidiano escolar como na pesquisa relacionada à infância, o olhar continua centrado na perspectiva da cultura do adulto, o que relega a participação efetiva da criança.

Essa íntima relação entre as concepções historicamente construídas de infância, e as formas de conceber e efetivar a socialização e a participação da criança no espaço educacional, seria um álibi bastante plausível para eximir a escola e os professores de qualquer responsabilidade a respeito dos limites estipulados para a socialização e a participação das crianças nas decisões referentes à escola, como aquela que apenas põe em prática conceitos construídos e perpetuados ao longo dos tempos da escola com sua dinâmica, metodologia e rotinas. Mas, agindo dessa forma, contribui simplesmente para a manutenção da condição passiva legada à criança.

Assim denuncia Buckingham (2007, p. 20):

\begin{abstract}
A escola [...] é uma instituição social que efetivamente define e constrói o que é ser criança - e uma criança de uma determinada idade. A separação pela idade biológica em vez de pela 'habilidade', a natureza altamente regulamentada da relação professor e aluno, a organização do currículo e do horário das atividades cotidianas, o processo de avaliação - todos servem de diferentes maneiras para reforçar e naturalizar pressupostos particulares a respeito do que as crianças são ou devem ser.
\end{abstract}

Uma educação escolar com, para e por meio de mídias em muito pode contribuir para a superação desse quadro que segrega as crianças à condição de sujeitos passivos, tanto na escola como na sociedade. 
Para isso, carecemos primeiro de um processo de formação que assegure ao professor saberes que possibilitem o entendimento de que "[...] 'a criança' não é uma categoria natural ou universal, determinada simplesmente pela biologia." Sendo assim, "[...] o significado de 'infância' está sujeito a um constante processo de luta e negociação, tanto no discurso público (por exemplo, na mídia, na academia ou nas políticas públicas) como nas relações pessoais, entre colegas e familiares." (BUCKINGHAM, 2007, p. 19).

Partindo dessa linha de raciocínio, apresentada por esse autor, parece-nos razoável afirmar que talvez o grande entrave para a construção de uma prática educativa participativa e midiática resida justamente nas concepções de infância legitimadas, sobretudo no processo de formação inicial dos professores. Com base nos estudos de Miranda (1986), depreendemos que as principais correntes pedagógicas estudadas, por vezes as únicas, compactuam da mesma ideia em relação à infância, tanto a Pedagogia Tradicional como a Pedagogia Nova difundem a noção de natureza infantil. Partindo desse suposto, mesmo concebendo "[...] a criança como um ser pleno para a auto-realização de cada etapa do desenvolvimento (p. 129)", e que contribua decisivamente para a construção de saberes mais adequados sobre a criança, a Pedagogia Nova "[...] não escapa de uma visão naturalista e biológica da infância, desconsiderando a condição histórico-social da criança." (p. 129).

Superar essa legitimação de uma concepção naturalista, universal da infância que supõe a igualdade de todas as crianças e propaga uma concepção abstrata de criança, já no processo de formação inicial, seria o primeiro passo em busca de garantir ao professor saberes para o desenvolvimento de processos de socialização que valorizassem a participação ativa das crianças, respeitadas em sua condição de ser social agente, produtor de cultura.

Um segundo passo seria resgatar o caráter dialético e dialógico do processo de ensino-aprendizagem por meio de uma Pedagogia da Comunicação, no sentido de oportunizar espaços de comunicação e interação tanto entre professores e alunos, como entre os próprios professores e entre os próprios educandos, potencializando o diálogo entre pares. Esse caminho é apontado por Penteado (1991, 2002, 2006) quando, com base nos estudos de Paulo Freire, fala-nos de uma prática pedagógica possibilitadora e potencializadora de ricas formas de socialização e participação ativa dos alunos, uma Pedagogia da Comunicação.

Em seu legado, ao mencionar a uma Pedagogia da Comunicação, Freire (1996, p. 25) se refere a uma ação educativa que seja capaz de "[...] atuar sobre a realidade social para transformá-la, ação que é interação, comunicação, diálogo. Educador e educando, os 
dois seres criadores libertam-se mutuamente para chegarem a ser, ambos, criadores de novas realidades".

Para alcançar tais objetivos, Porto (1998, p. 47-48) aponta três aspectos que devem ser considerados quando se busca desenvolver uma prática educativa fundamentada em uma Pedagogia da Comunicação:

$\checkmark$ A importância do prazer, da fruição e do envolvimento emocional na aprendizagem;

$\checkmark$ Os envolventes valores, modelos de conduta, carga artística que o espetáculo televisual apresenta, especialmente aos adolescentes, que vivem inúmeros problemas existenciais característicos desta faixa etária na construção de sua identidade;

$\checkmark$ A escola como um espaço cultural-educativo onde tal exposição possa ser revista, examinada e reelaborada, com vistas a contribuir para a construção de conhecimentos significativos para o desenvolvimento do raciocínio e para a formação da personalidade.

Para essa pedagogia, as mídias e seus discursos, principalmente a televisiva, são manifestações culturais passíveis da construção e da elaboração de conhecimentos sobre elas. Nesse processo, a utilização mecânica, automática e linear desses meios deve dar lugar a uma prática dialógica de construção de saberes, superando assim práticas tradicionais de ensino e aprendizagem. Assim, a Pedagogia da Comunicação "[...] não é uma pedagogia sobre os meios de comunicação. É uma pedagogia que estabelece comunicação escolar com os conhecimentos, com os sujeitos, considerando os meios de comunicação. Dialoga-se com os meios e suas linguagens, em vez de falar dos meios" (PORTO, 1998, p. 29), o que por si só exige outra postura do professor, que deve assumir a condição de mediador de aprendizagem.

Penteado (2006) reconhece não ser tarefa fácil trabalhar uma prática pedagógica dessa natureza, porém defende que ao comprometer-se com a construção de conhecimentos viabilizadores da cidadania dos seus alunos, o professor terá na Pedagogia da Comunicação recursos orientadores para sua prática docente. Dentre as possibilidades efetivas para tanto, Penteado (2006, p. 122) chega à seguinte conclusão:

Ao colocar em discussão junto aos alunos um problema, indagando, ouvindo e acolhendo as opiniões e considerações feitas, por mais divergentes que se apresentem, e expondo a sua visão do problema e a importância de sua focalização na escola, estará dando o primeiro passo dentro de uma metodologia comunicacional de ensino. 
O segundo passo rumo a uma metodologia comunicacional é motivar, instigar, desafiar os alunos a aprender o conteúdo trabalhado pelo professor. Em síntese, é possível dizer que, ainda, para Penteado (1999, 2002, 2006), a escola é essencialmente um espaço de comunicação, o que faz com que toda ação educativa seja também uma ação comunicativa. Assim, "ensino é comunicação". Nas palavras da autora, "não qualquer tipo de comunicação. Mas comunicação dialógica. Não meramente reprodutora, mas elaboradora do conhecimento." (1991, p. 112).

A compreensão e a manutenção do espaço da sala de aula como um lugar de diálogo e participação são condições indispensáveis para a efetivação da educação escolar enquanto um processo de ação/interação das crianças com o mundo exterior (BELLONI, 2007 , p. 113) - mundo esse que apresenta suas estruturas simbólicas e seu cotidiano profundamente marcados pela presença constante das mídias telemáticas e digitais.

No exercício da Pedagogia da Comunicação, o professor deve atentar para os seguintes aspectos:

[...] dar lugar à manifestação dos sujeitos educandos, desenvolverem sua competência linguística, propiciar o exercício social através do qual se apropriarão dessa ferramenta indispensável para sua elaboração conceitual. Em lugar de confiná-los a um mero papel de receptores, é preciso criar condições para que eles mesmos gerem mensagens próprias, pertinentes ao tema que estão aprendendo. (KAPLÚN, 1999, p. 73).

Em seus estudos a respeito dos processos de socialização infantil na cultura mediática que ora vivenciamos, Belloni (2009, p. 140-141) elenca quatro objetivos a serem atingidos para se compreender o papel das mídias na educação escolar das crianças:

$\checkmark \quad$ Ir além da análise dos discursos, do estudo de contextos (social, político e econômico) e da crença em abordagens clássicas e milagrosas;

$\checkmark$ Abrir as fronteiras entre os campos e tentar integrar estudos multi e interdisciplinares que possam dar conta da heterogeneidade e complexidade da infância e dos processos de socialização, onde atuam com intensidade e características diferentes elementos naturais e sociais, entre os quais, como um novo elemento complicador, a tecnologia, especialmente as TIC ou mídias;

$\checkmark$ Pôr em prática efetivamente a dupla hermenêutica das ciências sociais, realizando estudos que sejam também ocasiões de reflexão para as crianças e os adolescentes, bem como para os pesquisadores e educadores, numa perspectiva de mídia-educação;

$\checkmark \quad$ Integrar o estudo das mídias, como dispositivo essencial nos processos de socialização das novas gerações, a partir de uma perspectiva de mídiaeducação, isto é, considerando-os em dupla dimensão de objetos de estudo 
e como ferramentas pedagógicas já atuantes na vida cotidiana de todos em todas as esferas da vida social.

Uma ação nesse sentido, como indicada por Belloni (2009), exige do professor um minucioso planejamento das ações comunicativo-educacionais, sem o que, a ação formadora da escola por meio e com as diferentes mídias será pouco produtiva. Afinal, "[...] trazer os meios para a escola significa incorporar uma nova maneira de organizar a sociedade e reconhecer outras dinâmicas da cultura", que também é atingida pela ação da Indústria Cultural. (CITELLI, 2004, p. 84).

Por planejamento entende-se neste trabalho "[...] a organização processual de uma ação que possibilite visualizar e orientar o seu desempenho, rumo aos alvos pretendidos." (PENTEADO, 2002, p. 54). Concebido dessa maneira, o planejamento tem como elementos norteadores a finalidade, a realidade e um plano de ação, concebidos e considerados indispensáveis para a construção de uma educação com, para e por meio de mídias na escola.

Fundamentados por uma Pedagogia da Comunicação e desta organização de intencionalidades que constitui o planejamento, o professor terá em suas mãos condições adequadas para libertar-se do nível do "como e com o que fazer", que é um mecanismo ligado ao conteúdo e que geralmente leva à acomodação, e avançará para a condição "o que fazer e para que fazer", que é sobremaneira mais movente. Seguindo essa linha de pensamento, Vasconcelos (2000) concebe o planejamento como um mecanismo de integração do indivíduo com o contexto social e cultural em que está inserido. Dessa forma, dentro de um processo teórico-metodológico, intenta a realização de práticas articuladas, o que está em consonância com os fundamentos e métodos da Pedagogia da Comunicação na medida em que esta é constituída pelo agir comunicacional:

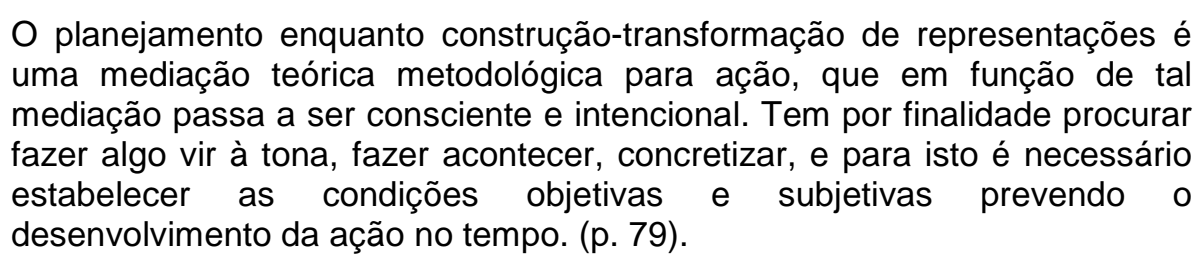

Enveredar por esses caminhos implica em romper com modelos tradicionais de planejamento em que sem informações imprescindíveis, como quem são efetivamente os sujeitos do processo educativo mediado pelo professor, o ato de planejar limita-se a cumprir uma burocracia pouco produtiva para a realização da prática educativa. Caminhar rumo a uma Pedagogia da Comunicação implica compreender o planejamento como um mecanismo a ser construído não somente pelo professor, mas na interação com os seus 
alunos, de forma processual e caracterizada pelo "[...] agir comunicacional que reconhece as interferências sociais e culturais nos processos de comunicação escolar." (PENTEADO, 2002, p. 43).

Ao construir saberes viabilizadores de uma ação educativa baseada em uma Pedagogia da Comunicação, o professor tem em suas mãos a possibilidade de contribuir para a construção de um novo projeto de sociedade. Formará sujeitos dotados de criticidade e criatividade que, no consumo das tecnologias midiáticas, sobretudo a televisiva, sejam capazes de desenvolver um olhar mais vivencial, crítico e reflexivo que possibilite a ressignificação das mensagens e conteúdos veiculados pelas mídias, a partir de seu contexto de recepção. 


\section{CAPÍTULO II}

\section{Metodologia}

\section{1- Título da pesquisa}

A educação das infâncias na sociedade midiática: desafios para a prática docente.

\section{2 - Problema de pesquisa}

Vivemos em uma sociedade globalizada, complexa, caracterizada por uma severa economia liberal, e indelevelmente marcada pela ação das mídias. Nessa sociedade, a grande exposição da criança às mídias massivas, em especial a televisiva, contribui decisivamente para a socialização em um mundo onde paradoxalmente a valores edificadores de uma sociedade justa, democrática e cidadã acabam dando lugar à alienação, à acomodação, ao ensimesmamento e ao consumo exagerado.

Munida de recursos tecnológicos como imagem, som, cores vibrantes e dinamicidade de movimento, não há como negar que hoje a televisão não apenas tem implicações no processo de ensino-aprendizagem escolar das crianças, mas é também constitutiva da própria infância contemporânea.

Essa realidade parece não muito clara aos professores que atuam na Educação Infantil. Na maioria das vezes, as práticas educativas com e para mídias em sala de aula transitam de práticas pontuais, que apenas cumprem as rotinas do currículo escolar, à quase negligência, quando a presença socializante dos meios de comunicação massivos da sociedade tecnológica é praticamente desconsiderada.

Frente a esse quadro, e considerando o descompromisso comumente manifestado pela TV com a educação das crianças e adolescentes, uma ação educativa escolar mediadora que oportunize às crianças já na Educação Infantil, uma relação sensível, vivencial, reflexiva e participativa com, para e através de mídias, sobretudo a televisiva, constitui uma ação indispensável na perspectiva de uma formação cidadã que viabilize a participação social de todos os indivíduos. 
Uma prática pedagógica fundamentada em uma Pedagogia da Comunicação que oportunize uma educação com a para mídias que tenha início já na Educação Infantil ainda esbarra em fatores como: uma concepção de infância ainda muito restrita à perspectiva biopsicológica comportamental que nega à criança a condição de sujeito social ativo produtor de cultura; uma limitação na percepção dos docentes a respeito da ação das tecnologias midiáticas, em especial a tevê, na educação das crianças; uma formação inicial e continuada de docentes que tem dificuldades em contemplar as atuais necessidades formativas das demandas que emergem da sociedade contemporânea.

\section{3 - Perguntas norteadoras}

Tal problematização encaminha-nos às seguintes perguntas de pesquisa:

1. Qual a concepção de infância dos professores de Educação Infantil?

2. Como esses compreendem possíveis influências da tevê, dentre outras mídias, na aprendizagem das crianças?

3. Que fundamentos teórico-metodológicos podem propiciar uma educação com e para mídia na Educação Infantil?

4. Como esses saberes teóricos podem contribuir para o desenvolvimento de metodologias que viabilizem uma educação nesse sentido?

5. De que forma uma educação com e para mídias pode contribuir para o exercício da cidadania das crianças?

\section{4 - Objetivo Geral}

Temos por objetivo geral nesta pesquisa delinear saberes que possibilitem a construção de um conhecimento pedagógico (teórico-metodológico) que promova uma educação com e para mídias na Educação Infantil, tendo em vista: iniciar as crianças em uma relação mais vivencial, sensível e reflexiva no consumo de mídias, sobretudo a televisiva; introduzi-las já nesse nível de ensino, de forma participativa, no exercício da cidadania já nas vivências escolares; com base na Pedagogia da Comunicação, promover um processo de formação continuada de professores da Educação Infantil no sentido de 
uma educação midiática; refletir a respeito da produção de conhecimentos necessários à formação inicial de professores.

\section{5 - Objetivos específicos}

São objetivos específicos deste trabalho:

1. Averiguar as concepções de infância dos professores da Educação Infantil.

2. Fazer um levantamento de como os professores da Educação Infantil compreendem possíveis influências da televisão na aprendizagem das crianças.

3. Investigar os principais hábitos de consumo da programação televisiva das crianças da Educação Infantil.

4. Promover juntamente com os professores da Educação Infantil a realização de atividades pedagógicas com a televisão na escola, e verificar as compreensões elaboradas por eles daí decorrentes.

\section{6 - Instrumentos para a coleta de dados}

Para a efetivação da coleta de dados e realização desta pesquisa, fizemos uso de quatro instrumentos:

a) Um questionário semi-estruturado recorrente com 35 questões abertas e fechadas que foi utilizado para registrar informações referentes às concepções dos sujeitos da pesquisa sobre a infância e sobre possíveis influências da tevê na aprendizagem das crianças. (anexo 3)

b) Um roteiro de entrevista semi-estruturado com perguntas que permitiam reforçar aquelas feitas no questionário, registrando os dois momentos, antes e depois da ação formadora vivenciada por este pesquisador junto com os professores sujeitos dessa pesquisa (Pesquisa Intervenção). (Mesmas perguntas apresentadas no questionário) 
c) Diário de bordo do professor-pesquisador (instrumento docente) para o registro pelos docentes das atividades realizadas em sala de aula com as crianças, e referentes aos encontros formativos característicos da pesquisa-intervenção.

d) Diário de bordo do pesquisador-pesquisador constitui-se enquanto um instrumento de registro das observações realizadas durante os encontros característicos da pesquisa-intervenção.

e) Registros fotográficos, em áudio e em vídeo de algumas atividades realizadas com o professor e com as crianças.

\section{7 - Delimitação do local e dos sujeitos da pesquisa}

A realização da ação pesquisadora-educativa ocorreu em uma escola municipal de Educação Infantil - Emei - da Cidade de Campinas, interior de São Paulo. Neste trabalho a identificaremos como Emei A, visto estar associada a mais duas escolas (Emei B e Emei C) que compõem um Centro Integrado de Educação Infantil - Cimei, localizado naquela área. A Emei A está localizada na região dos DICs - Distrito Industrial de Campinas. Atende à população daquela região e de áreas adjacentes ao DIC 4, bairro de periferia da referida cidade. Os sujeitos da pesquisa são duas professoras que atuam na Educação Infantil dessa escola juntamente com suas classes, compostas em média por 22 alunos. 40

\section{8 - Procedimentos para a coleta de dados}

Organizamos a ação pesquisadora em duas fases distintas, mas que se complementam constituindo um todo.

$\mathrm{Na} 1^{\text {a }}$ fase, a coleta de dados foi feita por meio de um instrumento (questionário) que foi construído pelo pesquisador com auxílio de sua orientadora de pesquisa. Esse instrumento foi aplicado pela $1^{\underline{a}}$ vez no primeiro encontro de formação $(E F)^{41}$ do referido Centro Integrado de Educação Infantil - Cimei, realizado no dia 29/04/2008 na Emei B, que igualmente compõe esse centro ${ }^{42}$. Naquele momento, solicitamos que as duas professoras

\footnotetext{
40 Por uma questão ética, optamos por não identificar o nome da escola nem dos sujeitos envolvidos na pesquisa. Assim, os nomes utilizados são fictícios e têm a função de situar o leitor desse trabalho de pesquisa.

41 Conforme denominação adotada pela Rede Municipal de Educação de Campinas.

42 Optamos por descrever mais precisamente nos itens 2.9 e 2.10. Lócus da pesquisa e caracterização dos sujeitos, respectivamente.
} 
da escola escolhida levassem o questionário para casa e respondessem as questões apresentadas, que visavam coletar as concepções de infância daquelas professoras da Educação Infantil e como elas compreendiam possíveis influências das mídias na aprendizagem das crianças. Caso tivessem dúvidas, essas seriam discutidas no retorno do instrumento ao pesquisador. Uma semana depois, as professoras pesquisadoras trouxeram o questionário parcialmente respondido, já que haviam tido dificuldade com algumas perguntas. Em conjunto, passamos, então, todas as perguntas do questionário fazendo a recorrência do instrumento que no momento assumiu a função de roteiro de entrevista. Essa etapa da pesquisa ainda se estendeu por mais um encontro para que todas as dúvidas suscitadas pelas perguntas fossem sanadas, facilitando com isso uma expressão mais precisa do pensamento das docentes.

$\mathrm{Na}$ segunda fase da pesquisa, a coleta de dados se efetivou no período de abril de 2008 a junho de 2009, somando um total de 31 encontros de formação (pesquisa-ensino), constituindo um processo de formação continuada. Foram organizados registros de dados coletados em observação direta e indireta do cotidiano escolar das professoras; registros feitos nos diários de bordo (do pesquisador e das professoras pesquisadoras); registros fotográficos e em áudio e vídeo, feitos pelo pesquisador professor, de algumas atividades realizadas nos momentos de observação, de entrevistas recorrentes, que foram gravadas, transcritas literalmente, respeitando as características do discurso oral, e reapresentadas às professoras pesquisadoras para que verificassem se era realmente aquele o seu real posicionamento em relação às perguntas apresentadas. Esse instrumento foi aplicado no início da pesquisa (diagnóstico, anterior à realização da pesquisa-ensino) e foi aplicado novamente durante e no final desse processo (posterior à formação realizada no contexto da pesquisa ensino).

\section{9 - Natureza da pesquisa}

Chegar a uma definição precisa sobre a abordagem adequada para a realização de uma pesquisa na área de humanidades geralmente não é tarefa fácil, afinal, no campo das ciências humanas, a pesquisa acadêmica caracteriza-se como: "[...] uma ação investigativa de fenômenos ou conceitos, problematizados de maneira teoricamente referenciada pelo pesquisador, e da qual se espera ou uma confirmação da teoria já existente, ou um acréscimo, ou mesmo uma superação." (PENTEADO, 2008, p. 04). 
Assim, para facilitar a escolha, optamos por começar revisitando alguns conceitos relacionados à pesquisa científica. O primeiro deles foi o de metodologia. De acordo com Minayo (1999), metodologia consiste no caminho percorrido pelo pesquisador para atingir sua meta.

Importante atentar que mesmo munidos de informações conceituais, na busca pela construção de outros conhecimentos por meio da pesquisa, muitas vezes, aprendemos que além das regras estabelecidas pelo método científico que nos referencia, temos que estar preparados para, a partir da criatividade, da imaginação, da objetividade e da persistência, buscar novos caminhos quando aqueles que havíamos planejado já não nos conduzem ao ponto que almejamos chegar. Caminhos que nos levem à descoberta de "novos" procedimentos reflexivos e sistemáticos, controlados e críticos, que nos permitam descobrir novos fatos e dados, relações ou leis, a respeito nossos sujeitos e/ou objetos de estudo. (ANDER-EGG, apud MARCONI; LAKATOS, 2001).

Seguindo essas pistas, para chegar até aqui, um dos nossos referenciais foi a obra de Lüdke; André (1986) Pesquisa em educação: abordagens qualitativas. Nesta obra, encontramos subsídios para trilhar nossos caminhos referendados por uma abordagem qualitativa. A respeito desse tipo de abordagem, as autoras citadas, baseadas na obra de Bogdan; Biklen (1982), apresentam cinco características principais da pesquisa qualitativa:

A primeira característica apresentada por Lüdke; André (1986, p. 11) dá conta de que "[...] a pesquisa qualitativa tem o ambiente natural como fonte direta de dados e o pesquisador como seu principal instrumento". Nesse sentido, indicam que a realização do trabalho de campo é fundamental posto que seja nessa etapa da investigação que o pesquisador terá contato direto com o ambiente, com a situação que está sendo investigada. Condição indispensável para que possa compreender as características constitutivas do ambiente, do grupo, da comunidade os quais investiga.

Nas palavras das autoras:

\begin{abstract}
A justificativa para que o pesquisador mantenha um contato estreito e direto com a situação onde os fenômenos ocorrem [...] é a de que estes são muito influenciados pelo seu contexto. Sendo assim, as circunstâncias particulares em que um determinado objeto se insere são essenciais para que se possa entendê-lo. Da mesma maneira as pessoas, os gestos, as palavras estudadas devem ser sempre referenciadas ao contexto onde aparecem. (p. 11).
\end{abstract}

A segunda característica tem a ver com a coleta de dados, a qual, segundo as autoras, deve ser predominantemente descritiva. Essa característica serve de alerta para o fato de que todos os dados da realidade referentes ao objeto e/ou aos sujeitos da pesquisa são relevantes ao pesquisador, "[...] que deve, assim, atentar para o maior número possível 
de elementos presentes na situação estudada, pois um aspecto supostamente trivial pode ser essencial para a melhor compreensão do problema que está sendo estudado." (p. 11 e 12).

Segundo Martins (2004, P. 52), a descrição nas pesquisas realizadas nas ciências humanas constitui um recurso básico que deve ser considerado no início de qualquer processo de investigação nessa área, visto que:

As ciências humanas não são, portanto, uma análise daquilo que o homem é na sua natureza, mas, antes, porém, uma análise que se estende daquilo que 0 homem é, na sua positividade (vivendo, falando, trabalhando,envelhecendo e morrendo), para aquilo que habilita este mesmo homem a conhecer (ou buscar conhecer) o que a vida é, em que consiste a essência do trabalho e das leis, e de que forma ele se habilita ou se torna capaz de falar.

A terceira característica considerada por Lüdke; André (1986, p. 12) considera que para a abordagem qualitativa, a preocupação com o processo é maior do que com o produto. Em outras palavras, as autoras afirmam que o pesquisador ao investigar um problema deve focar seu interesse em "[...] verificar como este problema se manifesta nas atividades, nos procedimentos e nas interações cotidianas.".

Essa característica serve de alerta ao pesquisador para que esse não se deixe entusiasmar com os resultados parciais ao ponto de perder o foco do todo que investiga. Assim, durante o processo de investigação, os resultados emergentes devem ser tomados como etapas do processo de investigação.

A quarta característica da abordagem qualitativa dá conta de que "[...] o significado que as pessoas dão às coisas e à sua vida são focos de atenção especial pelo pesquisador" (LÜDKE; ANDRÉ, 1986, p. 12). Analisando essa característica, observamos que essa constitui um grande desafio ao pesquisador posto que este deverá registrar as "perspectivas dos sujeitos investigados" diante das questões que estão sendo enfocadas. Os benefícios dessa ação para a prática da pesquisa consistem em: "Ao considerar diferentes pontos de vista dos participantes, os estudos qualitativos permitem iluminar o dinamismo interno das situações, geralmente inacessível ao observador externo." (p. 12).

A quinta e última característica, mas não menos importante que as demais, indica que "[...] a análise dos dados tende a seguir um processo indutivo" (p. 13), ou seja, ao realizar pesquisa que opte por abordagem qualitativa, o pesquisador não deve centrar seus esforços em encontrar as evidências que irão comprovar a sua hipótese pré-estabelecida. É na análise dos dados que as abstrações se formam e se consolidam, comprovando ou não a hipótese levantada.

O fato de não existirem hipóteses ou questões específicas formuladas a priori não implica a inexistência de um quadro teórico que oriente a coleta e 
a análise dos dados. O desenvolvimento de um estudo aproxima-se a um funil: no início há questões ou focos de interesse muito amplos, que no final se tornam mais diretos e específicos. O pesquisador vai precisando melhor esses focos à medida que o estudo se desenvolve. (LÜDKE; ANDRÉ, 1986, p. 13).

Em síntese, pode-se depreender das pesquisas qualitativas que, ao recorrermos a esse mecanismo do exercício da pesquisa, devemos nos preocupar basicamente com a análise e a contextualização do(s) sujeito(s) em estudo em uma realidade dinâmica, complexa e de múltiplas interações.

Com base nessas características das pesquisas qualitativas delineadas por Lüdke; André (1986), para atingir os objetivos propostos nesta pesquisa, optamos por fazer uso das possibilidades investigativas da Pesquisa-intervenção na modalidade de pesquisa-ensino, no desenvolvimento de um processo de formação continuada de professores da Educação Infantil. Nessa abordagem metodológica e investigativa, a ideia de ensino se junta à prática da pesquisa para produzir uma relação entre teoria e prática em que não há precedência de uma em relação à outra, mas um constante movimento que faz com que os resultados sejam invariavelmente convertidos em processos. Isso assegura uma dimensão essencialmente política, além de educativa, condição efetivada no desenvolvimento das atividades de campo.

Um trabalho de pesquisa-intervenção não tem como propósito a busca de conhecimento e positivação/otimização das estruturas estabelecidas, mas a viabilização de movimentos de desnaturalização de instituições que atravessam o processo educacional, como pedagogia, infância, normalidade e disciplina, sendo, portanto, potencializadora da produção de outros modos de subjetivação na formação acadêmica. (ROCHA, 2008, p. 482).

A opção pela Pesquisa-ensino como referencial para esta pesquisa se deu por essa estar em consonância com os objetivos e os movimentos que buscamos efetivar neste trabalho. Assim, ao indagar as concepções de infância dos professores e o que esses pensam a respeito das possíveis influências das mídias, principalmente a televisiva, na aprendizagem das crianças da Educação Infantil, uma abordagem que nos permite suspeitar dos lugares prontos e problematizá-los pareceu-nos muito convidativa. Além disso, afora nossos interesses acadêmicos e de formação pessoal, almejávamos também contribuir com a formação dos professores implicados na pesquisa.

Focalizada no processo de ensino-aprendizagem escolar, a Pesquisa-ensino concebe o processo de ensino-aprendizagem como um processo de caráter social que se realiza na relação que se estabelece entre professores e alunos com o conhecimento (PENTEADO, 2008c).

Sendo um fenômeno social, na modalidade pesquisa-ensino, esse processo apresenta as seguintes características: 
$\checkmark$ O pesquisador e o objeto de pesquisa são seres humanos e portanto sociais, e de comunicação, dotados de objetividade, de subjetividade e de capacidade de significação;

$\checkmark$ Enquanto tal, são orientados em suas ações docentes, discentes e de pesquisa, no caso aqui focalizado, por desejos, móveis da ação;

$\checkmark$ E desse modo dispõem de capacidade suficiente para efetuarem análises e avaliações de suas ações que permitem o discernimento dos desejos que impulsionam suas ações, das possibilidades e dos limites delas. (PENTEADO, 2008c, p. 03).

Além de debruçar-se sobre o processo de ensino-aprendizagem, outra condição bastante favorável para escolhermos tal modalidade de investigação consiste no fato de que nessa abordagem o pesquisador professor e os sujeitos envolvidos na prática da pesquisa (professor pesquisador) são sujeitos ativos que compartilham a ação da construção do conhecimento.

Sendo assim, faz parte do trabalho de pesquisa a análise das implicações do pesquisador com as instituições em jogo no campo da investigação:

[...] as práticas que constituem o social e os referenciais que the dão sentido vão se produzindo concomitantemente, uma vez que o conhecimento e a ação a respeito da realidade são constituídos no curso da pesquisa de acordo com as análises e decisões coletivas, dando à comunidade participante uma presença ativa no processo. (ROCHA, 2006, p. 169).

Ao ter como base o suposto de que ensinar e comunicar são ações indissociáveis, outro aspecto da modalidade Pesquisa-ensino que vem ao encontro de nossas perspectivas com este trabalho é a sua abordagem do ser humano, que é concebido como um ser social, nessa condição, também um ser de comunicação, um comunicador midiático, visto também atuar como suporte de veiculação, propagação de informação. (PENTEADO, 2008c).

Desse modo, faz-se "[...] importante a análise da história dos grupos, da política educacional, dos projetos e práticas constituintes na/da escola como também das próprias relações do coletivo em pesquisa - análise das implicações." (ROCHA, 2006, p. 171). Inserido em tal contexto, o pesquisador não é exterior ao campo da pesquisa, ele está sempre implicado nesse.

$\mathrm{Na}$ Pesquisa-ensino, a produção de conhecimento e de práticas se dá em um mesmo movimento. "O conhecimento se constrói, assim, entre o saber já elaborado e incorporado nos pressupostos do pesquisador e o fazer enquanto produção contínua que organiza a ação investigativa". (ROCHA, 2006, p. 169). O pesquisador então sabe que intervém, que intercede, necessariamente, no campo pesquisado.

Nessa intercessão poderão ser produzidos novos sentidos, pois é o momento em que: 
[...] o docente pesquisador do ensino básico conta com a assessoria teórica de pesquisadores professores universitários, e estes têm a oportunidade de se aproximarem vivencialmente do fenômeno estudado, pelas relações comunicacionais que mantém com os sujeitos do fenômeno de pesquisa no ensino básico. (PENTEADO, 2008c, p. 6).

Diversa de outras abordagens metodológicas, os fundamentos da Pesquisa Intervenção negam a possibilidade de neutralidade da presença do pesquisador na pesquisa de campo. Consideram ainda que por tratar-se de uma construção compartilhada de conhecimentos, os saberes do pesquisador não devem ser privilegiados frente àquilo que sabem os pesquisadores participantes. A forma de abordagem da pesquisa intervenção põe em questão a relação sujeito-objeto de conhecimento e mostra-nos que ambos se caracterizam no mesmo processo.

Parâmetros como os de verdade, neutralidade, objetividade, universalização de saberes são questionados e as mudanças que se processam ao longo da/na pesquisa, implicam em transformações também dos sujeitos envolvidos e das práticas estabelecidas quer para a população participante na pesquisa, quer para os pesquisadores. (ROCHA, 2006, p. 169).

Fundamentada em bases como a indissociável relação entre o pensamento e a ação e a construção do conhecimento compartilhado resultante de um comprometimento político e ético, a Pesquisa-ensino caracteriza-se essencialmente por seu caráter político. Além disso, deve também constituir-se como uma proposição de ação transformadora que, potencializada pela atuação conjunta do pesquisador com o grupo social investigado (quando sujeitos, pesquisadores participantes), estabeleça uma intervenção de ordem micropolítica.

Caracterizada dessa forma, a Pesquisa-ensino tem no fluxo dos discursos emergentes no trabalho de campo um rico arsenal de elementos a serem analisados. $\mathrm{Na}$ prática da Pesquisa-ensino é comum que os sujeitos participantes narrem suas histórias a partir de uma experiência vivenciada, que é, ao mesmo tempo, singular e coletiva. Nesse movimento, esses fluxos de discursos eclodem na construção discursiva de saberes compartilhados sobre a produção subjetiva de cada um, mecanismo essencial para compreensão do todo.

Assim, neste tipo de análise, sentimentos, pensamentos, ideias soltas, na Pesquisa Intervenção são considerados dispositivos importantes de análise. Tal característica faz essa abordagem ideal para a observação das formas de produção de conhecimento que ocorrem entre crianças, jovens e adultos. "Nesse tipo de pesquisa o informante fornece dados para a construção do conhecimento ao mesmo tempo em que aprende sobre o fenômeno pesquisado e gera conhecimentos." (PENTEADO, 2007, p. 124). 
Ao partir de uma situação idealizada, a Pesquisa Intervenção tem por objetivo gerar conhecimentos práticos, úteis e acionáveis, o que faz com que seja uma metodologia potencializadora de uma nova relação entre indagar e agir, já que a própria indagação já se constitui como ação e como uma nova relação entre os sujeitos implicados nos processos de ensino/investigação.

\subsection{0 - Lócus da pesquisa}

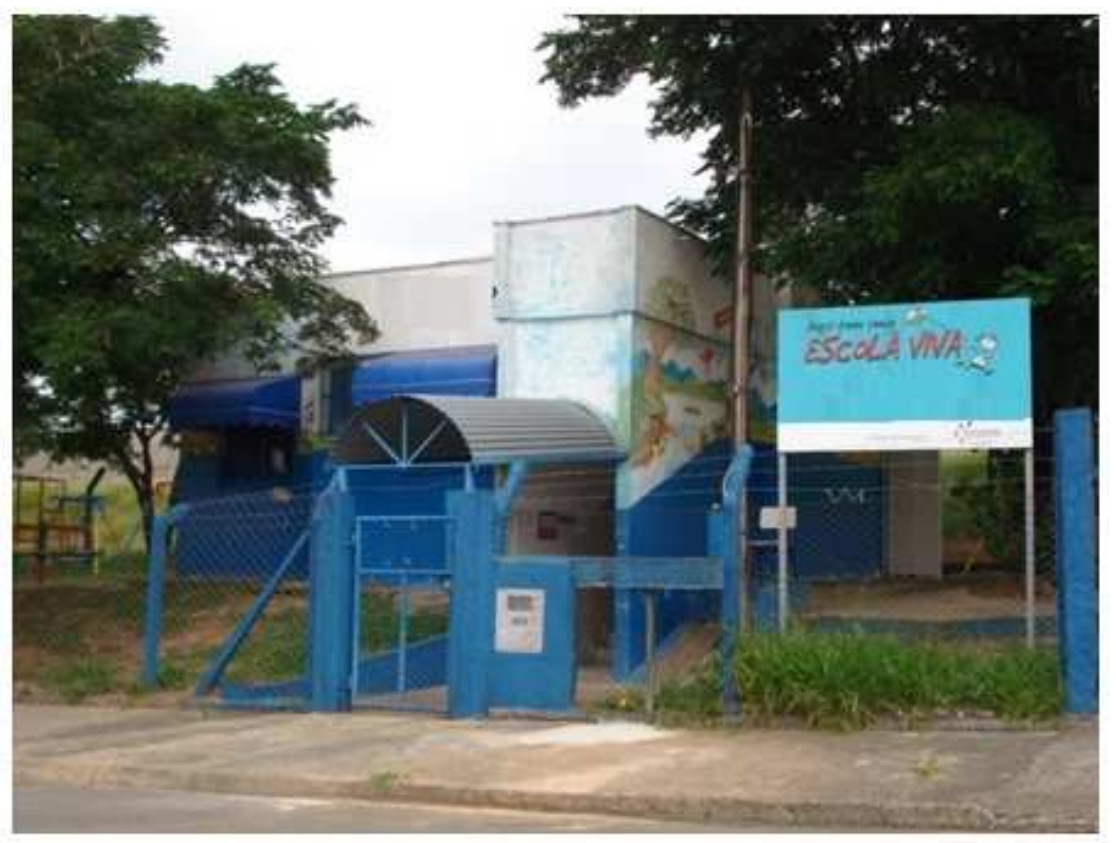

Figura 19: Emei A, instituição onde foi realizada a pesquisa. ${ }^{43}$

A escola selecionada para a realização desta foi uma escola municipal de Educação Infantil da cidade de Campinas-SP, Emei A. A escolha dessa instituição de ensino para a realização deste exercício de pesquisa se deu por uma série de fatores, os quais elencamos a seguir.

Em primeiro lugar, mesmo ciente de que as dificuldades seriam maiores, nosso desejo era trabalhar com uma instituição de ensino pública, afinal foi nessa esfera que nos formamos professor, que desenvolvemos nossa prática e que agora nos dava a oportunidade de retornar a essa esfera, na condição de pesquisador-professor;

Em segundo, o fato de essa instituição de ensino estar localizada em uma periferia relegada da cidade de Campinas, na região dos DIC's ${ }^{44}$, especificamente no bairro DIC IV.

\footnotetext{
43 Fotos 19 - acervo do pesquisador.

${ }^{44}$ Distrito Industrial de Campinas.
} 
Uma região onde muitos moradores, e isso também inclui as crianças da escola, além de padecerem com a privação de bens essenciais, como moradia própria, ruas asfaltadas, serviços adequados de água e esgoto, serviços de saúde eficaz e outras carências advindas da falta de vontade política dos governos, sofrem com o preconceito de morar em uma região "mal vista" pela sociedade campineira; 45

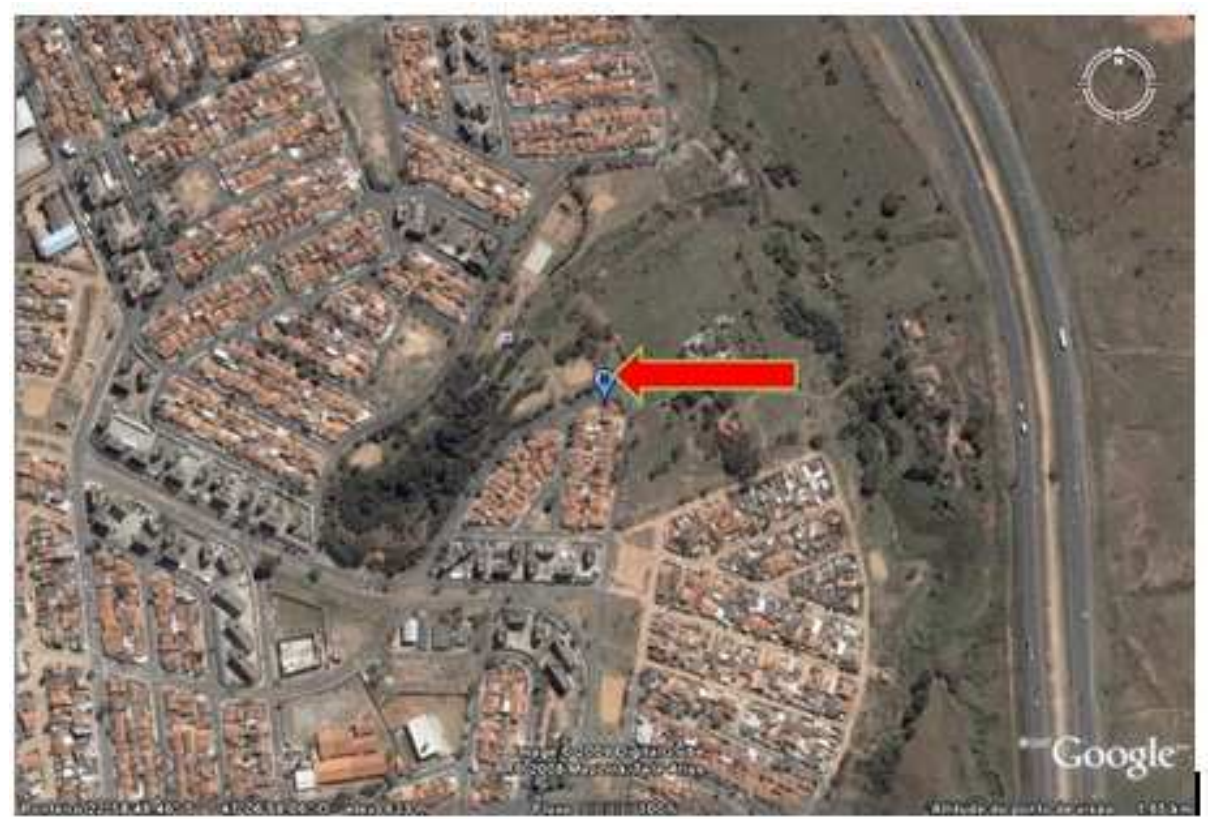

Figura 20: Imagem aérea de localização da área onde se encontra a escola investigada. 46

Em terceiro lugar, a possibilidade de acesso, permanência e logística na referida escola, concedida tanto por parte da direção como das professoras que atuam na escola (anexos 1 e 2), condição indispensável para realização da pesquisa;

Em quarto lugar, nosso contentamento em poder colaborar com a formação continuada de toda aquela comunidade escolar, já que além das professoras com quais iria trabalhar efetivamente, acordamos com a Direção que colaboraríamos, igualmente, com os encontros de formação (EF) trazendo profissionais da aérea de educação para socializar saberes com aquele grupo escolar. ${ }^{47}$

Por último, mas não menos importante, a possibilidade de termos como sujeitos colaboradores crianças que convivem com muitas exclusões. Exclusões que, em muitos casos, não se limitam às mídias eletrônicas como os computadores, a Internet, mas até

\footnotetext{
45 Além do preconceito por tratar-se de uma área de periferia, é também nos DICs que se concentra a principal zona de baixo meretrício da cidade mencionada.

46 Fonte: 〈http://www.google.com/intl/pt-PT/earth/index.html>

${ }^{47}$ Ao longo do ano colaborei em dois momentos com os encontros de formação, um deles encontra-se registrado no item caracterização dos sujeitos, o outro será registrado na análise de dados.
} 
mesmo o acesso a mídias massivas, como a tevê. O que nos pareceu no momento, um grupo social ideal para os nossos propósitos de pesquisa.

A Emei pesquisada é uma escola pública de Educação Infantil mantida pela Prefeitura Municipal de Campinas. É uma das três unidades que compõem o Centro Integrado Municipal de Educação Infantil - Cimei $X$ - localizado naquela região. Além da Emei $A$, como doravante identificaremos nosso lócus de pesquisa, o referido Cimei é constituído por mais uma unidade no DIC V (Emei B) e outra no DIC IV, (Emei C). Todas as três unidades funcionam em dois períodos, manhã e tarde, compreendendo um horário de funcionamento das $7 \mathrm{~h} 30 \mathrm{~min}$ às $16 \mathrm{~h} 30 \mathrm{~min}$. Todas atendem ao agrupamento III, o qual delega à escola a obrigação de atender a crianças que estejam em idades de 3, 4, 5 e 6 anos.

O Cimei X responde à administração da Naed - Núcleo de Ação Educativa Descentralizada que contempla a região sudoeste da cidade. Além da Naed sudoeste, a Secretaria Municipal de Educação de Campinas conta com mais quatro, uma na zona leste, outra na zona noroeste, uma na norte, e a que abarca a zona sul do município.

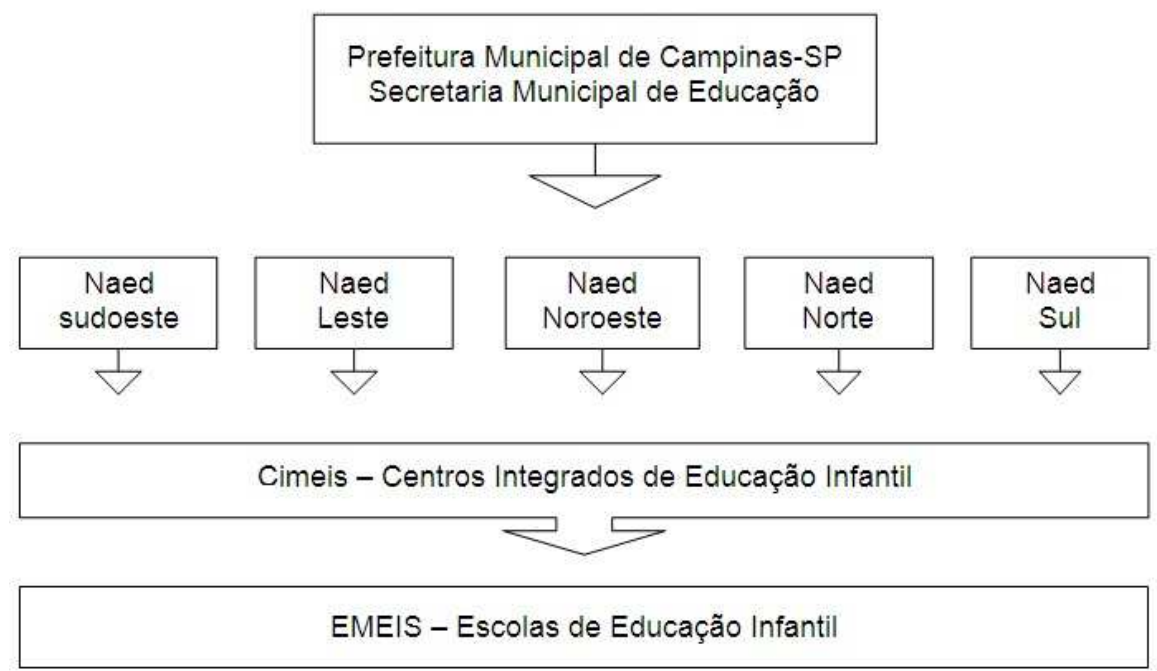

Figura 21: Organograma da ação administrativa da Secretaria Municipal de Educação de Campinas-SP.

Em 2004, a Prefeitura Municipal de Campinas concentrava 150 unidades de Educação Infantil - entre Creches e Emeis. A soma desse conjunto de instituições dava à Rede a capacidade de atender 28,6 mil crianças de 0 a 6 anos. No ano de 2008, a Prefeitura deu início a um projeto que pretende edificar 15 novas unidades de ensino denominadas "Nave Mãe". As futuras escolas de Educação Infantil de Campinas contemplam em sua estrutura salas de aula, sala multiuso, área administrativa, enfermaria, pátio coberto, refeitório, cozinha, sanitários para funcionários e para as crianças. Além disso, devem também dispor de espaço para oferecer aulas de cursos profissionalizantes e da EJA (Educação de Jovens e Adultos). O objetivo dessa empreitada da administração pública 
municipal de Campinas é ofertar nos próximos anos 8 mil vagas às crianças da Educação Infantil, eliminando assim o déficit quantitativo e, posteriormente também o déficit qualitativo. 48

O Cimei X conta com uma Diretora Educacional e uma Orientadora Pedagógica, ambas com graduação em Pedagogia. A Diretora além da graduação em Pedagogia é graduada em Letras e tem mestrado em Linguística Aplicada. A Emei B dispõe de seis professoras efetivas, todas com Magistério Médio e Pedagogia, algumas com especialização lato sensu. A Emei $C$ conta com duas professoras, ambas efetivas e com Magistério Médio e Pedagogia; uma delas cursa doutorado em Educação. Já a Emei A, lócus desta pesquisa, tem em seu quadro duas professoras efetivas e uma substituta; as duas efetivas têm Magistério Médio e Pedagogia, uma delas faz especialização em Educação Infantil, a substituta tem Magistério Médio e é formanda do curso de Pedagogia (curso concluído no final do ano de 2008).

Além do pessoal docente, cada uma das unidades que compõem o Cimei X, conta apenas com mais três funcionários: uma Servente, uma Merendeira e um Vigilante. 49

Muitas limitações caracterizam a estrutura física da Emei $A$, todas elas justificadas pelo prédio não ter sido projetado para ser uma escola, menos ainda uma escola de Educação Infantil. A unidade escolar funciona em um protótipo de apartamento popular adaptado, composto por pequenos cômodos: uma cozinha, um refeitório, uma sala que serve de secretaria, sala de tevê e vídeo e biblioteca, uma sala de aula, uma área onde as crianças guardam as mochilas, escovam os dentes e guardam os brinquedos e jogos, e um único banheiro que atende a toda a comunidade escolar, inclusive as crianças.

Vale registrar ainda que a escola não dispõe de condição alguma de receber crianças que tenham alguma limitação física, não possui rampas, banheiro adaptado, máquina de Braille...

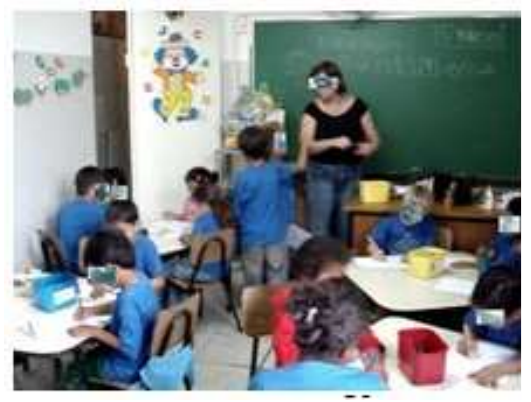

Figura 22: Sala de aula. 50

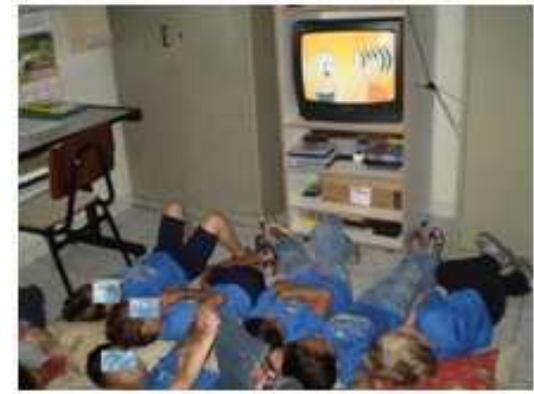

Figura 23: Secretaria, TV, vídeo e

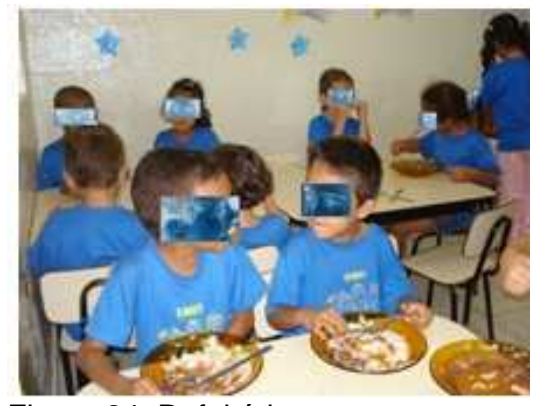

Figura 24: Refeitório.

\footnotetext{
48 Conforme registrado no site da Secretaria Municipal de Campinas acessado em 31 de agosto de 2004 <http://www.campinas.sp.gov.br/smenet/noticias/noticia_2004_08_31.htm> e em 13 de novembro de 2008 <http://www.campinas.sp.gov.br/smenet/noticias/noticia_2008_11_13.htm>.

49 Conforme informações disponíveis no Projeto Político Pedagógico do CMEI 24 relativo ao ano de 2007, o referente ao ano de 2008 não havia sido homologado pela Rede.
} 

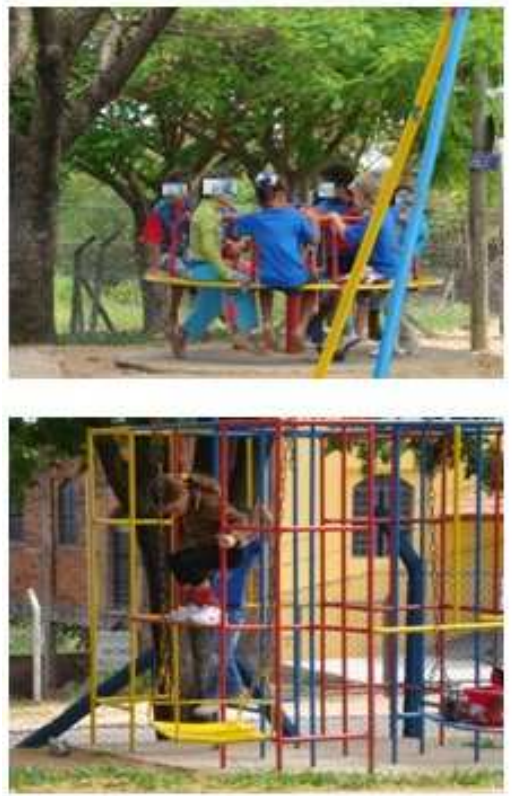

Figura 25 e 26: Playground.

biblioteca.

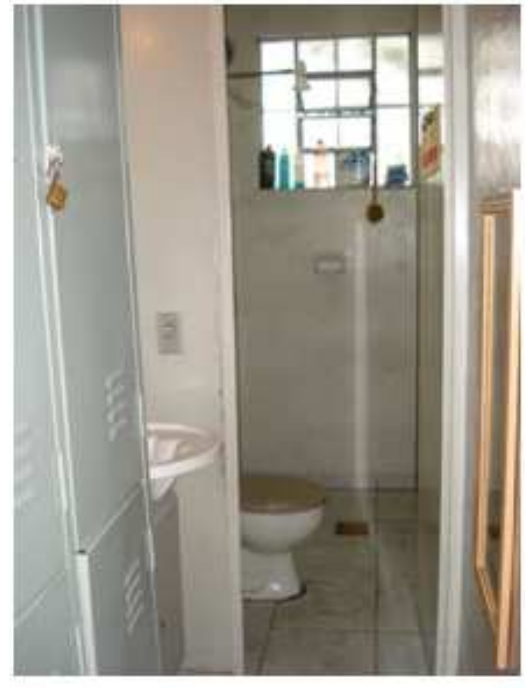

Figura 27: Banheiro coletivo para todos os sujeitos que circulam pela escola (crianças, professores, funcionários...).
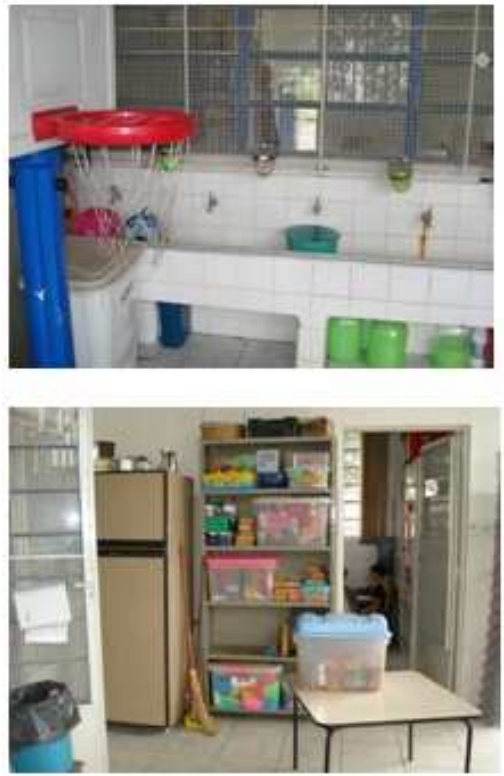

Figura 28 e 29: área onde escovam os dentes e guardam as mochilas.

No espaço externo, do lado direito, há uma área cimentada arborizada onde as crianças brincam, fazem atividades e apresentações aos pais em dias de festa, atrás da escola, há uma caixa de areia, e de ambos os lados da escola ficam os brinquedos do playground. Dentre as muitas reclamações das professoras em relação à estrutura física da escola, essa disposição dos brinquedos do parque é uma das que mais incomoda, pois o fato de não conseguirem visualizar todas as crianças enquanto brincam acaba fazendo com que deixem de presenciar muitos incidentes e acidentes que ocorrem durante as brincadeiras no parque.
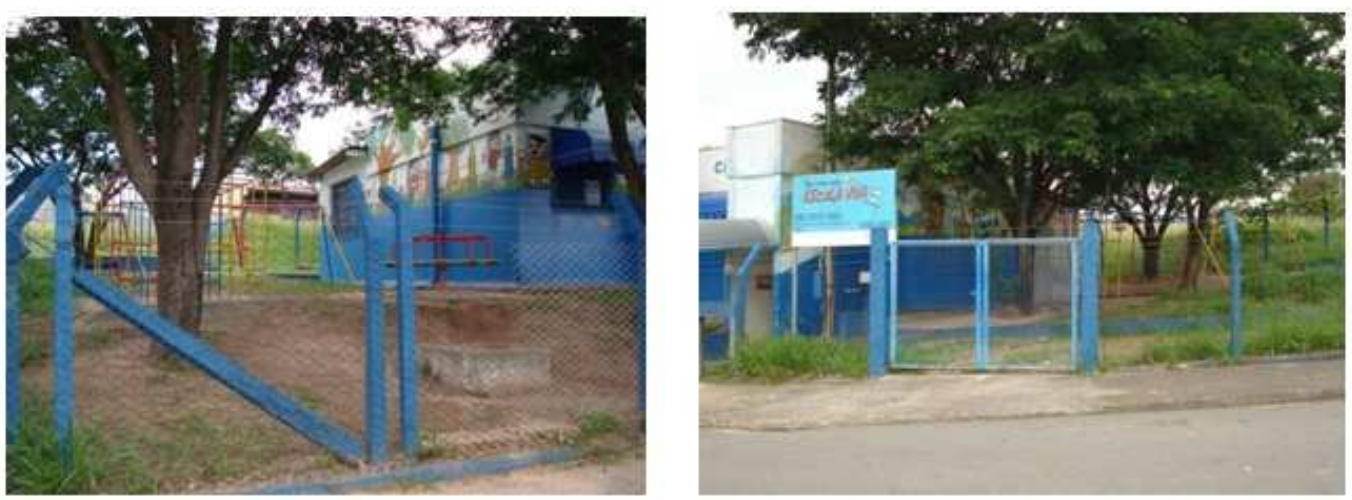

Figuras 30 e 31: Disposição do playground, escola cercada por um alambrado. ${ }^{51}$

\footnotetext{
${ }^{50}$ Fotos 22 a 29 - acervo do pesquisador.
}

51 Fotos 30 a 31 - acervo do pesquisador. 
Percebemos também que essa dificuldade enfrentada pelas professoras no dia-a-dia escolar, em relação à disposição do parquinho, é agravada em virtude de a escola não contar com um muro, mas apenas um alambrado. Essa condição possibilita que pessoas que passam pela rua, nos momentos de atividades externas, tenham contato com as crianças, até mesmo sem que as professoras vejam. Consideramos esse registro importante, afinal são consideráveis os índices de violência nessa região da cidade.

Outro aspecto da estrutura que também causa desconforto é o mato alto encontrado na lateral esquerda e nos fundos da escola, o qual além de servir de refúgio para insetos e até mesmo animais peçonhentos, também representa um risco para a comunidade escolar.

Em relação a equipamentos eletrônicos de uso no cotidiano educacional, foco de interesse desta pesquisa, a escola conta com apenas um computador com acesso à Internet discada que serve única e exclusivamente para o uso pessoal das professoras, da secretaria e de outros funcionários que trabalham na escola. As crianças não têm acesso a esse equipamento. Dispõe também de um aparelho de som, que permanece na sala de aula, um vídeo cassete, uma televisão e um aparelho de DVD que ficam na sala multiuso da secretaria. $O$ fato de haver apenas um exemplar de cada um desses aparelhos dificulta em muito o trabalho das professoras, pois quando um desses equipamentos "quebra", a burocracia, a carência de recursos financeiros aliada à necessidade de suprir apenas coisas mais urgentes faz com que meses sejam necessários para efetuar o conserto. Um registro dessa situação ocorreu logo que chegamos à escola. De acordo com relatos das professoras, naquele momento o aparelho de DVD estava no conserto. Quando perguntamos quando ficaria pronto, elas recordaram que da última vez havia levado três meses para consertar.

Essa escassez de espaço que caracteriza a Emei A é também observada na Emei C, a qual dispõe de condições físicas semelhantes às observadas na Emei A. Isso implica em que, apesar de as professoras dessas duas instituições de ensino desenvolverem seu horário de trabalho docente individual (TDI) 52 no mesmo local onde trabalham, sejam obrigadas a se deslocar para a Emei $B$, que dispõe de um espaço um pouco maior, isso ocorre todas as vezes que o Cimei realiza uma reunião coletiva (com as três unidades), como ocorre por exemplo com os TDC - trabalho docente coletivo. Também por conta dessa carência de espaço e por reunir um número maior de classes, a Direção do Cimei concentra suas atividades administrativas e de gestão pedagógica apenas na Emei $B$, realidade também verificada em relação ao trabalho de Orientação Pedagógica.

\footnotetext{
52 Horário remunerado, oportunizado exclusivamente aos professores efetivos da Rede, o qual o professor deve cumprir na escola desenvolvendo atividades relativas a sua prática pedagógica. Conforme nomenclatura adotada pela Rede Municipal de Educação de Campinas - SP.
} 
A Emei $\mathrm{A}$ atende à comunidade do próprio DIC IV e de áreas adjacentes. Conforme levantamento realizado em 2007 pela própria unidade de ensino, o grupo social que tem seus filhos matriculados nessa unidade de ensino apresenta as seguintes características: $66 \%$ não são de Campinas (migrantes de outras cidades); $64 \%$ das mães desenvolvem atividades profissionais fora do lar, enquanto $36 \%$ limitam-se ao serviço doméstico; em relação às práticas de leitura, $1 \%$ do grupo afirmou não ler, $3 \%$ indicaram leituras diversas, $11 \%$ leem gibis, $38 \%$ são leitores da bíblia, e $47 \%$ disseram que leem jornais e revistas.

\subsection{1 - Caracterização dos sujeitos}

As características dos sujeitos da pesquisa também em muito interferiram na escolha da escola, afinal, diverso do que encontrava nas outras unidades do Cimei, A Emei A dispunha de uma profissional com mais de 10 anos de formada, professora pesquisadora 1 (Pro.1) ${ }^{53}$, e uma ainda em formação, professora pesquisadora 2 (Pro.2), condição temporal e profissional estas bastantes instigantes para nosso projeto de pesquisa.

Além disso, consideramos também o fato de naquele momento nenhuma delas ter outra formação inicial completa, além da graduação, outra condição que consideramos favorável, já que estaria lidando com os saberes teóricos construídos na graduação; desse modo, o processo formativo que propúnhamos poderia ser mais bem avaliado em seus efeitos.

Outro aspecto propício foi a receptividade e a acolhida de ambas as professoras, especialmente da que já estava formada há mais de 10 anos. Foi visível sua reação favorável quanto a participar da pesquisa, ainda mais quando soube que pela natureza da pesquisa adotada, pesquisa-intervenção, ela também seria pesquisadora de sua prática. Sentiu-se tão instigada que já naquele momento queria saber detalhes quando começariam nossos encontros, como seriam as atividades...

Com o intuito de conhecer melhor nossas companheiras de jornada investigativa pedagógica, elaboramos um roteiro com 35 perguntas abertas e fechadas coerentes com os objetivos da pesquisa. Esse foi aplicado no dia 29 de abril de 2008, quando o Cimei X realizou sua primeira reunião pedagógica do ano de 2008, oportunidade na qual fomos apresentados à comunidade escolar interna, especialmente ao grupo de professores.

\footnotetext{
53 Para efeito de organização, a partir deste ponto do trabalho identificaremos essa professora como Pro.1e a outra professora como Pro.2.
} 
Naquela ocasião, estavam reunidas uma diretora educacional, uma orientadora pedagógica, seis funcionárias de apoio (três serventes e três merendeiras) e o corpo docente, composto por onze professoras. Após a palavra da Direção, os informes e os professores do Cimei apresentarem seus projetos para o ano de 2008, fomos convidados a apresentar com mais propriedade nosso trabalho de pesquisa, ressaltando nossos interesses acadêmicos na investigação e a contribuição que legaria à Emei escolhida e ao Cimei $X$ como um todo. Também nesse momento, legitimando o combinamos com a Direção, palestramos sobre o nosso tema de pesquisa, posteriormente passamos a palavra à Professora Dra. E. G. G., a qual dialogou com o grupo sobre o tema "A creche como instituição educativa". A professora Dra. E. G. G. é especialista em avaliação na Educação Infantil e, que naquele momento, colaborou conosco falando a respeito dessa temática. ${ }^{54}$

Refletindo sobre nosso primeiro encontro, vemos o quanto isso foi providencial, afinal esclareceu ao grupo que diverso das experiências que haviam tido com pessoas que passaram por lá em busca de dados para suas pesquisas, embasados pela metodologia da pesquisa intervenção, também estávamos lá para colaborar, para dialogar, para aprender com cada um e com o grupo.

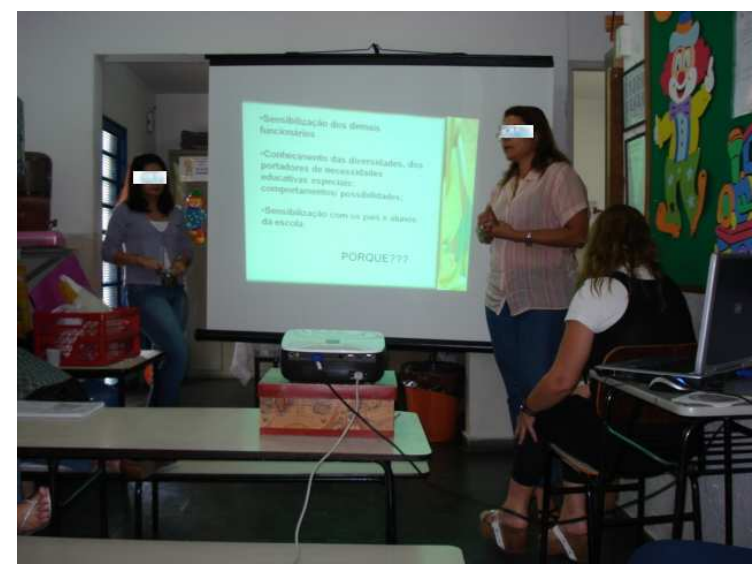

Figura 32: 1e encontro de formação pedagógica do Cimei X. Professores apresentando seus projetos. (acervo do pesquisador). 55

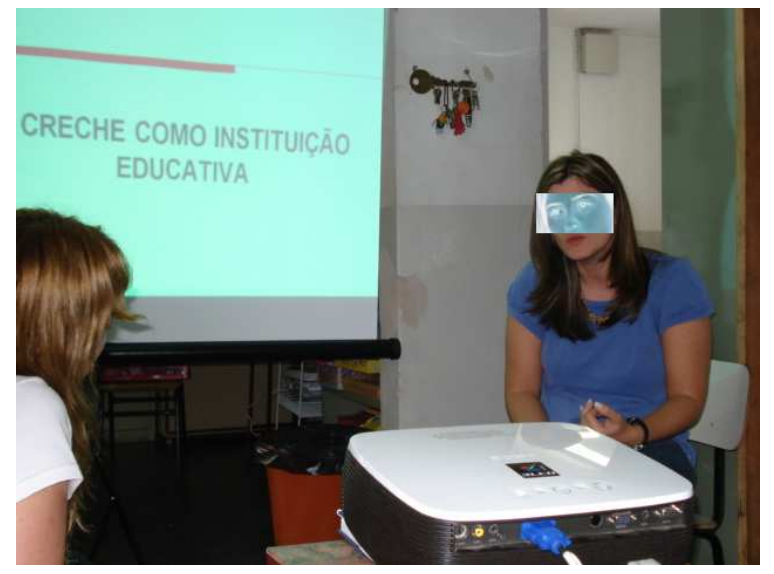

Figura 33: Conversa com a Profa . Dra. E. G. G. (acervo do pesquisador).

\footnotetext{
54 Ao longo do ano de 2008, além dessa primeira colaboração nos encontros de formação do grupo, fui convidado a participar apenas em mais dois momentos. Isso ocorreu por conta de o grupo ter elegido outras prioridades para esses encontros, como acréscimos culturais: idas a teatros, cinemas, museus (em Campinas e São Paulo)... Os registros destes outros encontros, inclusive fotográficos apresentaram futuramente no capítulo de análise de dados, visto esses terem ocorrido no decorrer da pesquisa de campo.

${ }^{55}$ Fotos 31 a 35 - acervo do pesquisador.
} 


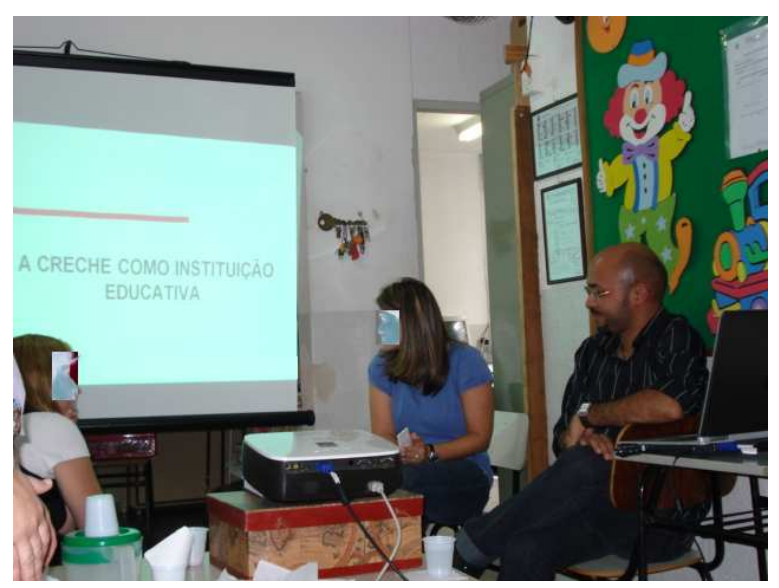

Figura 34: Conversa com este pesquisador. (acervo do pesquisador).

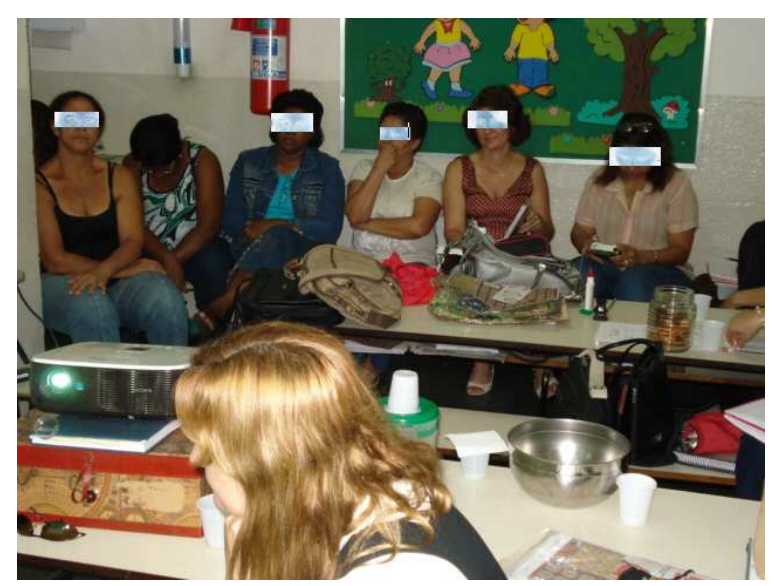

Figura 35: Alguns membros da Comunidade escolar do Cimei X. (acervo do pesquisador).

Após essa atividade, finalmente tivemos a oportunidade de um momento com nossas companheiras de pesquisa, quando marcamos para responder às perguntas do questionário. Com o intuito de não deixar escapar aquela empolgação, perguntamos às professoras pesquisadoras Pro.1 e Pro.2 se elas aceitariam levar o instrumento e respondêlo em casa, assim teriam mais tempo e ficariam mais à vontade para responder. Em um primeiro momento ficamos temerosos com medo de nos deparar com respostas prontas, simuladas, porém, como haveria uma entrevista recorrente, resolvemos apostar.

Ir ao DIC IV sozinhos, já que da última vez estávamos na companhia da professora Dra. E. G. G., fez com que nos deparássemos com nossos próprios preconceitos, pois foi nesse momento que percebemos claramente que mesmo que de forma velada, também estávamos surpresos em ver que os DICs não eram todo aquele mar de miséria e violência que a mídia campineira, dia a pós dia, mostrava. Essa constatação em muito contribuiu para que também nos permitíssemos ver além daquilo que estava construído em nosso imaginário a respeito da vida e das pessoas que moravam nos DICs.

Assim teve início nosso primeiro encontro na Emei $A$, onde fomos bem recebido por todos, inclusive pela professora pesquisadora Pro.1 que já estava lá à nossa espera, cheia de dúvidas, incertezas a respeito do que havia dito no questionário. Segundo ela, as questões sugeridas fizeram com que ela se auto avaliasse que colocasse em questão saberes que até então considerava ter todo o domínio. Foi assim que demos início à leitura das perguntas e respostas e que efetivamos a recorrência do questionário, agora em forma d entrevista, nas questões em que havia dúvida pedimos que a professora pesquisadora, Pro.1, fosse assinalando com um $\mathrm{X}$, para que posteriormente pudéssemos repensar as considerações feitas dando à pergunta uma resposta mais fiel ao seu modo de pensar. 
Nesse momento fomos colocando em cheque se aquilo que havia dito era o que realmente acreditava em relação ao questionamento feito. À medida que percebia que ela tinha mais algo a dizer, pedíamos que fosse registrando com uma caneta de cor diversa daquela que havia usado para responder às questões da primeira vez. Da mesma maneira que procedemos com a professora pesquisadora Pro.1, fizemos com a professora pesquisadora Pro.2, que chegou um tempo depois, também com algumas dúvidas, mas bem mais tranquila que a professora pesquisadora Pro.1. Dentre os motivos de sua tranquilidade, suspeitávamos que a Pro.2 não estivesse tão envolvida com pesquisa quanto a primeira professora.

Foi dessa forma que conhecemos um pouco mais as professoras pesquisadoras participantes deste trabalho, em um primeiro momento sabendo a respeito suas vidas pessoais, formação e trajetória docente; em um segundo momento, sabendo um pouco mais sobre o que pensavam a respeito de questões relevantes da pesquisa, como a infância, a aprendizagem das crianças, a ação das mídias no cotidiano infantil...

A Pro. 1 está em uma faixa etária compreendida entre os 36 e 40 anos, é casada, tem dois filhos adolescentes, tem renda familiar entre 8 a 10 salários mínimos, o que no nosso país lhe garante uma condição social de classe média ${ }^{56}$. Ela fez Magistério Médio, é formada em Pedagogia e, no decorrer da pesquisa ensino, deu início a um curso de especialização (lato sensu) em Educação Infantil (concluído em março de 2009). Atua no magistério da Educação Infantil há mais de 7 anos, é professora efetiva da Rede Municipal de Campinas, o que Ihe dá certa estabilidade e alguns direitos, como o de cursar uma pósgraduação em uma universidade pública custeada pela Rede e ter um horário de trabalho docente individual remunerado. Apesar de locomover-se em seu próprio carro até o local de trabalho, não reside muito distante da escola.

Em sua residência tem acesso a diversos meios de informação, como jornais, tevê, telefone celular, revistas, livros, rádio, computador e Internet, meios de comunicação de acesso típicos da classe média. A professora pesquisadora assiste de uma a três horas de TV todos os dias no período da noite. No seu dia-a-dia, para manter-se informada utiliza os seguintes meios de comunicação: livros, como exemplo citou o último que leu "Por uma cultura da infância"57; revistas; jornais diários como "Diário do Povo" e "Jornal Já", dois exemplares da mídia impressa popular de Campinas; telejornais, como "Jornal Nacional" e "Jornal Regional da Campinas"; e Internet, não citando nenhum site em especial.

\footnotetext{
56 De acordo com o Atlas da Nova Estratificação Social do Brasil - Classe Média - Desenvolvimento e Crise que considera inclusas nessa faixa os grupos sociais que ganham entre $\mathrm{R} \$ 2.275$ e $\mathrm{R} \$ 25.200$. Disponível em $<$ http://lists.indymedia.org/pipermail/cmi-saoluis/2006-December/1218-ri.html >. Acesso em :-13 dez., 2008,

57 Obra das professoras e pesquisadoras Ana Lucia Goulart Faria; Zélia de Brito Fabri Demartini,e Patrícia Dias Prado, Autores Associados, 2002. Um das leituras obrigatórias de um curso que fazia na Faculdade de Educação da Unicamp, custeado pela rede.
} 
A professora pesquisadora Pro. 2 tem idade compreendida entre 21 e 25 anos, é solteira, não tem filhos e mora com os irmãos. Fez Magistério Médio e no ano de 2008 era concluinte do curso de Pedagogia de uma faculdade privada da cidade de Campinas. Atua há pouco tempo no magistério da Educação Infantil, entre um e três anos. Na rede municipal é professora substituta, tendo durante a realização da pesquisa, em 2008 , realizado provas do concurso público da Rede e sido aprovada. O fato de não ser efetiva na Rede exclui a professora pesquisadora de muitos benefícios, como o horário de trabalho docente individual remunerado, por exemplo. Sua renda familiar também é de classe média, variando entre 5 e 7 salários mínimos. Em sua residência tem acesso a mídias como tevê, revistas, livros, rádio, telefone celular, computador e Internet. A professora pesquisadora Pro.2 assiste a programação televisiva entre 4 e 5 dias por semana, somando um total que varia entre 3 e 5 horas por semana, geralmente no período da noite.

Para manter-se informada, no seu cotidiano faz uso dos seguintes meios de comunicação: livros, como o "Afetividade e práticas pedagógicas" 58, por exemplo; jornais impressos, como o "Correio Popular" de Campinas; telejornais, como o "Jornal Nacional", "Jornal da Globo" e "Jornal Regional de Campinas"; sites da Internet, a exemplo do UOL; e também informa-se ouvindo programas de rádio.

A professora pesquisadora Pro.2, na Educação Infantil, não esconde seu desejo em trabalhar em creches e com bebês, para ela trabalhar com as crianças de colo é de um imenso prazer. Já a professora pesquisadora Pro.1 prefere trabalhar com as crianças maiores, diz sentir falta da interlocução com os pequenos, de observar o desenvolvimento das crianças, especialmente no que se refere à linguagem deles.

58 Livro de Sérgio Antônio da Silva Leite, Casa do Psicólogo, 2006. 


\section{CAPÍTULO III}

\section{Sobre os dados recolhidos}

\subsection{Circunstâncias e finalidades da coleta de dados}

A educação é permanente não porque certa linha ideológica ou certa posição politica ou certo interesse econômico 0 exijam. A educação é permanente na razão, de um lado, da finitude do ser humano, de outro, da consciência que ele tem de finitude. Xas ainda, pelo falto de, ao longo da história, ter incorporado à sua natureza não apenas saber que vivia mas saber que sabia e, assim, saber que podia saber mais. $\mathcal{A}$ educação e a formação permanente se fundam ai. (FRETRE, 1997, p. 20).

Esta pesquisa se insere no contexto daquelas que buscam, nas culturas escolares instituídas e vivenciadas pelos profissionais da educação, elementos que permitam perspectivar possibilidades de superação de problemas que afligem os processos de formação docente, tanto aqueles desenvolvidos pelas instituições de ensino superior (faculdades, centros universitários e universidades), compreendidos como processos de formação inicial, como aqueles que caracterizam uma formação permanente, e que geralmente ocorrem nos locais de atuação desses profissionais, especialmente nas escolas. Esses processos devem ser caracterizados essencialmente pela troca de experiências e pela partilha de saberes, o que constitui esses espaços como ambientes de formação mútua, em que cada professor é chamado a desempenhar, simultaneamente, os papéis de formador e formando, visto que, em conjunto com seus pares e seus alunos, ora pode assumir a condição de "ensinante", ora a de "aprendente." (NÓVOA, 1997).

Esse segundo processo de formação será mencionado aqui como formação continuada. Optamos por essa nomenclatura, dentre muitas outras, seguindo a indicação da declaração de Genebra, de 1996 (PERRENOUD, 2000). Estamos cientes de que a obrigatoriedade de uma formação continuada não está restrita à profissão docente. Desde as últimas décadas do século $\mathrm{XX}$, e mais ainda neste século, esse processo se tornou um caminho sem volta em todas as áreas, palavra de ordem na maioria das profissões. No caso das escolas, por exemplo, esse processo também abarcaria outros profissionais da educação, como os diretores, os orientadores educacionais, os supervisores pedagógicos e 
os administradores escolares. Porém, fiéis ao nosso objetivo de trabalho, centraremos nossos esforços especificamente na formação continuada dos professores.

Outro fator que nos leva a restringir nosso foco de interesse e análise é a convicção de que, diversamente dos outros profissionais da educação, a formação docente não se limita apenas aos espaços que formalmente são oportunizados pelas administrações escolares. Conscientemente ou não, para se constituírem docentes, os professores buscam subsídios teóricos e metodológicos nos mais diversos espaços. Nessa diversidade, merece especial atenção a escola, sobretudo aquela em que o professor atua, pois conforme Nóvoa (1997), dois elementos são essenciais para a formação docente, o próprio indivíduo em si, que precisa assumir a função de sujeito agente, e a escola, como um lugar legitimado do crescimento profissional e permanente do professor.

Também o próprio objetivo da formação continuada está em perfeita sintonia com aquilo que reivindicamos nesta pesquisa: uma formação pedagógica que possibilite, por meio de uma Pedagogia da Comunicação, oportunizar uma educação com e para as mídias às crianças da Educação Infantil, e que se estenda ao longo da vida discente. Afinal, a formação continuada se configura como um processo que visa oportunizar aos profissionais da educação discussões sobre teorias e metodologias atuais, emergentes, e, a partir disto, propor "novas formas" de ensinar e aprender que contribuam efetivamente para a ressignificação de teorias e práticas que se fazem necessárias para a melhoria da ação pedagógica na escola e da educação como um todo (NÓVOA, 1995a; PERRENOUD, 2000).

Considerando o contexto histórico brasileiro, os processos de formação continuada tiveram início por aqui já na década de 1980; porém, somente na década seguinte se efetivaram, de fato e de direito, práticas relevantes para a constituição da formação docente. Ao longo da trajetória histórica e sócio-epistemológica desse outro processo de formação, uma grande diversidade de tendências e concepções de educação e de sociedade, emergentes da realidade brasileira, tem gerado também diferentes tendências na formação continuada de professores. Dentre os muitos processos formativos desenvolvidos, há uma tendência latente de formar professores em serviço com base em uma orientação teóricoconceitual crítico-reflexivo.

Tomando-se por base essa orientação, que institui a prática reflexiva como principal referência para a formação docente continuada, não se pode deixar escapar também o princípio de que este processo deve efetivar-se em serviço, em períodos e horários adequados à realidade docente, de forma que se respeite a "profissionalidade" docente, evitando assim que a formação continuada se torne sinônimo de "opressão continuada".

Esclarecer esses aspectos significa caminhar no sentido de renunciar, romper com a ideia de que a formação continuada de professores deve ser apenas um processo de 
atualização que possibilita o acesso a informações científicas, didáticas, psicopedagógicas descontextualizadas da prática pedagógica do professor, para assumir uma concepção de formação que consiste em construir conhecimentos teóricos e metodológicos sobre a prática docente, a partir de vivências e reflexões críticas.

Ao insistirmos em realizar as atividades de pesquisar e ensinar, aspectos que caracterizam nossa natureza de pesquisa (pesquisa-ensino), no âmbito da formação continuada, isto se também justifica por concordarmos com D’Ambrósio (2003), quando adverte que o professor, como todo indivíduo inserido na dinamicidade acelerada da sociedade midiática em que vivemos, igualmente, tem conhecimentos limitados, sabe pouco, e, por mais que ele conclua seu curso superior, que se torne um profissional da educação, mesmo assim continuará sabendo pouco. Para ele, o fato de experienciarmos uma profusão cada vez maior de informações no cotidiano faz com que o conhecimento se desenvolva muito mais rapidamente do que se possa imaginar. Isso faz com que, mesmo inserido em um processo de formação inicial, a formação docente praticada pelas instituições de ensino superior atenda a um currículo essencialmente teórico, com conteúdos pré-determinados, descontextualizados com a realidade ora vivenciada, na maioria das vezes, inviabilizando que os saberes emergentes do cotidiano, do aqui e agora, sejam trabalhados na formação de professores. Assim, conforme D’Ambrósio (2003, p. 75): "Cinco anos depois de aprender algo, a gente sabe muito menos em relação ao que se passa hoje e ao novo conhecimento".

Especificamente no que se refere a uma formação pedagógica viabilizadora de uma Pedagogia da Comunicação, capaz de oportunizar aos alunos uma educação com e para as mídias, o problema que aponta D’Ambrósio (2003) torna-se mais complexo ainda. A impressão que fica é que estamos frente a um ciclo vicioso, pois, de acordo com Penteado (2007, p. 100):

[...] professores dessas escolas também foram formados em escolas do mesmo tipo, onde a produção do conhecimento e a pesquisa em ensino ou se encontravam ausentes, ou debilmente desenvolvidas; a didática do processo de ensino/aprendizagem era tratada de forma fragmentada e descontextualizada; os diferentes tipos de textos midiáticos, de forte efeito pedagógico, presentes no processo de socialização, eram ignorados ou rejeitados.

A superação desse quadro, conforme ensina essa pesquisadora, implica em reconhecer as condições em que os processos de formação se efetivam; compreender, por exemplo, que o contexto histórico vivenciado pelos professores durante sua formação inicial não é o mesmo da escola atual, já que outras são as demandas, as necessidades, os desafios experienciados pelos discentes. Isso implica, sobretudo, que as culturas e as 
práticas docentes também sejam repensadas, ressignificadas. Daí a relevância inconteste da formação continuada para a formação docente, principalmente no sentido de uma Pedagogia da Comunicação, de uma educação com e para as mídias na escola, uma vez que as mídias eletrônicas aí estão, e vieram para ficar, e cada vez mais são acessadas, admiradas e consideradas, especialmente por crianças e jovens, cuja socialização vem sendo significativamente pautada por elas, especialmente pela televisão.

Nessa perspectiva, a formação dos profissionais da educação para atender às novas demandas escolares exige mudanças significativas nos processos de formação inicial e/ou continuada, transformações que envolvem repensar conceitos como aprender, ensinar, habilidades, competências, tempos e espaços de aprendizagem. Além disso, esses processos também não podem mais se limitar a teorias que não dão conta de promover a aprendizagem escolar, que precisa ser vista como processo ativo e construtivo, que envolve o educando em sua totalidade, em seus fatores cognitivos, afetivos e sociais, e inclui os aspectos intuitivos, imaginários e criativos como implicações a serem consideradas. "[...] torna-se necessário preparar o professor para utilizar pedagogicamente as tecnologias na formação de cidadãos que deverão produzir e interpretar as novas linguagens do mundo atual e futuro." (SAMPAIO e LEITE, 2001, p. 15).

Trabalhada dessa maneira, a formação passa a operacionalizar-se em um processo permanente em que formação inicial e continuada se complementam, proporcionando ao professor um estado de constante formação, uma característica bastante valorizada na atual sociedade midiática, como afirma Lévy (1999).

$\mathrm{Na}$ concepção de Freire (1979), faz-se necessária uma 'formação permanente' também chamada de 'formação continuada' (NÓVOA, 1992), cujas ideias de formação valorizam o conhecimento do professor e, por meio de um processo interativo/reflexivo, buscam contribuir para uma análise de o próprio fazer pedagógico.

Conforme assinala Nóvoa (1992), nessa perspectiva de uma formação continuada, educar/formar fundamenta-se em três eixos estratégicos: a pessoa do professor e sua experiência; a profissão e seus saberes; e a escola e seus projetos.

Nas palavras desse pesquisador:

A formação não se constrói por acumulação (de cursos de conhecimento ou de técnicas), mas sim através de um trabalho de reflexão crítica sobre práticas e de (re)construção permanente de uma identidade pessoal. Por isso é tão importante investir na pessoa a dar estatuto ao saber da experiência (NÓVOA, 1992, p. 38).

Assim como Nóvoa (1992), Kramer (1994) também alerta para a relevância da prática escolar para a aquisição de saberes construídos na vivência do cotidiano pessoal e 
profissional. Segundo essa pesquisadora, esse é um movimento que acontece dentro de um contexto historicamente construído, permeado pelas tensões sociais de cada época e pela interação de cada sujeito com estes fatores.

Como podemos ver, o processo de formação docente, para Nóvoa (1992), não se limita apenas ao crescimento pessoal e ao aperfeiçoamento profissional, mas tem a ver também com a transformação da cultura escolar, que inclui a implementação e a consolidação de práticas participativas e de gestão democrática. Ele defende a ideia de que "[...] os professores precisam assumir-se enquanto produtores de sua formação [...] e essa formação passa por processos de investigação, diretamente articulados com as práticas educativas." (NÓVOA, 1992, p. 28).

Essa necessidade de uma formação continuada apontada por Nóvoa (1992) e Freire (1979), a partir de 1996, também passou a ser indicada no texto da Lei de Diretrizes e Bases da Educação Nacional (Lei Federal no 9.394/96), sancionada pelo então presidente da república Fernando Henrique Cardoso em 20 de dezembro de 199659. No Título VI, que trata Dos Profissionais da Educação, defende-se a seguinte postura:

"Art. 61 A formação de profissionais da educação, de modo a atender aos
objetivos dos diferentes níveis e modalidades de ensino e as características
de cada fase do desenvolvimento do educando, terá como fundamentos:
I a associação entre teorias e práticas, inclusive mediante a
capacitação em serviço;
II aproveitamento da formação e experiências anteriores em instituições
de ensino e outras atividades (BRASIL, 1996)

Em seus estudos, Belloni (1999) aponta um caminho bastante razoável para atender às exigências formativas dessa lei, bem como para o enfrentamento das novas demandas escolares. Para ela, a formação do educador hoje deve perpassar por três dimensões intimamente imbricadas umas às outras:

Pedagógica: relativa às concepções epistemológicas, dentre as quais destacamos as teorias construtivistas e sócio interacionistas;

$\checkmark$ Didática: referente à formação específica do professor, em uma das áreas do conhecimento;

$\checkmark$ Tecnológica: a qual abrange as relações entre tecnologia e educação, na utilização proficiente dos meios disponíveis, na avaliação e seleção de vídeos, softwares, tecnologias digitais e outros materiais técnico-educacionais, bem como na elaboração de estratégias de uso destes meios.

Em última instância, uma atuação eficaz dos profissionais de ensino no sentido de atender às novas demandas emergentes, sobretudo na perspectiva de uma educação com e

59 Na LDBEN 9394/96 (Lei de Diretrizes e Bases da Educação Nacional), no título "Dos profissionais da educação", podemos observar pelo menos três artigos destinados a fundamentar a formação inicial e continuada de professores, os artigos 61, 63 e 67. 
para as mídias, além de conhecimentos teóricos, didáticos, metodológicos e técnicos, carece também de estar contextualizada com o dia a dia vivenciado, com o tempo presente, o aqui e agora, em que estão inseridas a escola e os sujeitos que nela se encontram e vivenciam as relações próprias do processo de ensinar e aprender. (SACRISTAN, 1995; NÓVOA, 1995a, 1995b, 1998a, 1998b; FREIRE, 1999; PIMENTA, 1999; PERRENOUD, 2000; PENTEADO, 2002).

Feitas tais considerações, neste nosso exercício de pesquisa, partindo do princípio de que o processo de formação inicial e o processo de formação continuada devem, acima de tudo, constituírem-se enquanto processos complementares, nos tópicos a seguir, registramos parte do nosso esforço de contribuir para a melhoria destes processos. Para isso, por meio de nossa pesquisa empírica em uma escola pública de Educação Infantil e da colaboração de duas professoras-pesquisadoras, buscamos alcançar possibilidades de superação de obstáculos apontados/sugeridos pelas próprias professoras e também frutos de nossas observações do cotidiano escolar, e reflexões conjuntas e individuais sobre ele, vivenciadas no decorrer destes processos.

\subsection{Quadro descritivo dos encontros realizados durante a pesquisa}

\begin{tabular}{|c|c|}
\hline 1 encontro: & $\begin{array}{l}\text { Apresentação do pesquisador-professor e e professoras- } \\
\text { pesquisadoras. Entrega do questionário. }\end{array}$ \\
\hline 2 encontro: & $\begin{array}{l}\text { Reflexões relativas ao questionário: concepções de infância, mídia, } \\
\text { aprendizagem infantil e prática docente. }\end{array}$ \\
\hline 3ㅇ encontro: & $\begin{array}{l}\text { Discussão a respeito da relação do homem com a natureza e a } \\
\text { cultura. (Texto: A Cultura, Marilena Chauí). }\end{array}$ \\
\hline $4^{\circ}$ encontro: & $\begin{array}{l}\text { O homem como consumidor e produtor de cultura: culturas de adultos } \\
\text { e culturas da infância. (Texto: Os saberes das crianças e as } \\
\text { interações na Rede, Sandra Marlene Barra e Manuel Jacinto } \\
\text { Sarmento, 2008). }\end{array}$ \\
\hline 5 encontro: & $\begin{array}{l}\text { História, crianças, culturas infantis e mídias. (Vídeo: Crianças, Regina } \\
\text { Casé; texto: Cultura lúdica, Gilles Brougere). }\end{array}$ \\
\hline 6 encontro: & $\begin{array}{l}\text { Culturas docentes e educar na sociedade contemporânea (Animação: } \\
\text { Zoom - memorial de professor). }\end{array}$ \\
\hline $7^{\circ}$ encontro: & $\begin{array}{l}\text { Educação das crianças na sociedade contemporânea. Folclore e } \\
\text { imaginação. (Telas de Pieter Brueghel). }\end{array}$ \\
\hline 8ㅇ encontro: & $\begin{array}{l}\text { Imagem e representação: do mundo editado à edição do mundo. } \\
\text { Semiótica e representação. (Telas de Vincent Van Gogh e }\end{array}$ \\
\hline
\end{tabular}




\begin{tabular}{|c|c|}
\hline & apresentação ilustrativa em PowerPoint). \\
\hline 9e encontro: & $\begin{array}{l}\text { EF - Encontro de Formação Coletivo com professores das três } \\
\text { Emeis. Tema: Letramento e Educação Infantil, professor M. Sc. J. L. } \\
\text { M., convidado do pesquisador. }\end{array}$ \\
\hline 10 encontro: & $\begin{array}{l}\text { Culturas da infância, cultura lúdica e Educação Infantil. (Texto: Dos } \\
\text { folguedos à diversão digitalizada, Elza Dias Pacheco). }\end{array}$ \\
\hline 11ㅇe encontro: & $\begin{array}{l}\text { Culturas infantis e Indústria Cultural. Mercantilização da Infância. } \\
\text { (Apresentação em PowerPoint). }\end{array}$ \\
\hline 12ㅇe encontro: & $\begin{array}{l}\text { Educação, comunicação e tecnologias na escola: por uma pedagogia } \\
\text { da comunicação. (Apresentação em PowerPoint). }\end{array}$ \\
\hline 13ㅇe encontro: & $\begin{array}{l}\text { Planejamento e elaboração da sequência didática com a animação } \\
\text { Maria Flor. (Apresentação em PowerPoint). }\end{array}$ \\
\hline 14ㅇe encontro: & $\begin{array}{l}\text { Desenvolvimento da sequência didática com a animação Maria Flor. } \\
\text { (Conversa na roda e desenhos). }\end{array}$ \\
\hline 15e encontro: & $\begin{array}{l}\text { Desenvolvimento da sequência didática com a animação Maria Flor. } \\
\text { (Teatro filmado). }\end{array}$ \\
\hline 160 encontro: & $\begin{array}{l}\text { Apresentação do longa-metragem Kiriku e a feiticeira; socialização do } \\
\text { vídeo com as crianças, desenvolvendo as atividades da sequência } \\
\text { didática desencadeadas pela animação Maria Flor (produzida pelo } \\
\text { pesquisador-professor e pela professora-pesquisadora). }\end{array}$ \\
\hline 17을 encontro: & $\begin{array}{l}\text { Apresentação de algumas produções feitas com as crianças durante } \\
\text { o ano, na última reunião de pais e mestres do ano. }\end{array}$ \\
\hline 18ㅇ encontro: & Festa do Papai Noel. \\
\hline 19e encontro: & $\begin{array}{l}\text { Socialização com a Pro.1 e a coordenadora pedagógica da escola do } \\
\text { texto apresentado no nosso exame de qualificação (24/03/09), com } \\
\text { apresentação de um roteiro de atividades a serem desenvolvidas no } \\
1^{\circ} \text { semestre de } 2009 \text {. }\end{array}$ \\
\hline 20ํencontro: & $\begin{array}{l}\text { Socialização das atividades desenvolvidas pela professora no } \\
\text { período anterior à retomada dos trabalhos da pesquisa em 2009: } \\
\text { desenvolvimento da sequência didática com o desenho animado A } \\
\text { moda amarela. }\end{array}$ \\
\hline 21ㅇe encontro: & $\begin{array}{l}\text { Segunda recorrência das perguntas respondidas no questionário } \\
\text { apresentado às professoras no início da pesquisa. }\end{array}$ \\
\hline 22 encontro: & $\begin{array}{l}\text { Planejamento e elaboração da sequência didática com a reportagem } \\
\text { do telejornal "Hoje" a respeito da alimentação e desenvolvimento das } \\
\text { crianças, e com o desenho animado do personagem Chico Bento }\end{array}$ \\
\hline
\end{tabular}




\begin{tabular}{|c|c|}
\hline & (Maurício de Souza) "Aqui na roça é diferente". \\
\hline 23ㅇe encontro: & $\begin{array}{l}\text { Desenvolvimento da sequência didática com a reportagem do } \\
\text { telejornal "Hoje" a respeito alimentação e desenvolvimento das } \\
\text { crianças, e com o desenho animado "Aqui na roça é diferente". (As } \\
\text { crianças assistiram ao filme, conversaram a respeito e produziram } \\
\text { uma pirâmide alimentar com recortes de revistas). }\end{array}$ \\
\hline 24ํecontro: & $\begin{array}{l}\text { A professora, sob a orientação do pesquisador-professor, criou uma } \\
\text { roleta e pastas individuais para as crianças estudarem os bichos que } \\
\text { apareceram no filme do Chico Bento; cada criança fez sua roleta e } \\
\text { ilustrou sua pasta. }\end{array}$ \\
\hline 25e encontro: & $\begin{array}{l}\text { Reflexões a respeito dos aspectos positivos e negativos das } \\
\text { atividades realizadas pela professora com as crianças no encontro } \\
\text { anterior. Discussão sobre as múltiplas possibilidades de socialização. } \\
\text { Planejamento e elaboração da sequência didática com o desenho } \\
\text { animado "O Pica-pau" (escolhido pelas próprias crianças). }\end{array}$ \\
\hline 26e encontro: & $\begin{array}{l}\text { Desenvolvimento da sequência didática com o desenho animado "O } \\
\text { Pica-pau": conversa e desenho. }\end{array}$ \\
\hline 27을 encontro: & $\begin{array}{l}\text { Desenvolvimento da sequência didática com o desenho animado "O } \\
\text { Pica-pau": construção de um jogo de regras com as ações positivas e } \\
\text { negativas do personagem Pica-pau. }\end{array}$ \\
\hline 28ㅇe encontro: & $\begin{array}{l}\text { Desenvolvimento da sequência didática com o desenho animado "O } \\
\text { Pica-pau": construção de um jogo de regras com as ações positivas e } \\
\text { negativas do personagem Pica-pau. }\end{array}$ \\
\hline 29encontro: & $\begin{array}{l}\text { EF - Encontro de Formação Coletivo com professores das três } \\
\text { Emeis. Tema: As ciências no cotidiano e a Educação Infantil, } \\
\text { professora M. Sc. R. Ap. de F., convidada do pesquisador-professor. }\end{array}$ \\
\hline 30e encontro: & Terceira e última recorrência do roteiro de perguntas. \\
\hline 31ํe encontro: & Avaliação e encerramento das atividades de pesquisa. \\
\hline
\end{tabular}

Cabe ressaltar que, ao nos propormos a vivenciar o cotidiano da Emei $A$, nos colocando também na condição de colaboradores, por algumas vezes, mesmo tendo sido previamente planejados, os encontros de pesquisa-ensino acabaram assumindo outras funções. Isso ocorreu devido ao fato de que, acima do controle dos processos que buscávamos operacionalizar, colocamos a condição de observadores, perguntadores que buscam registrar e refletir sobre o cotidiano experienciado. 


\section{3 - Natureza dos encontros e procedimentos de análise}

Os encontros de pesquisa ocorreram no período de abril de 2008 a junho de 2009, previamente agendados, uma ou duas vezes por semana de acordo com a disponibilidade horária e organizacional das professoras. O grupo se encontrava exclusivamente na escola e no horário de trabalho docente individual da Pro.1, compreendido entre $11 \mathrm{~h} 30 \mathrm{~min}$ até por volta das $13 \mathrm{~h}$. Nossos encontros ocorriam geralmente no refeitório, por vezes na sala de aula ou no pátio.

Procurávamos cumprir o calendário da escola, assim, não nos encontramos nos períodos de férias e recesso das professoras. Para efeito de análise, os dados recolhidos nesses 31 encontros realizados foram organizados em cinco eixos temáticos, os quais apresentamos resumidamente no organograma a seguir, e mais detalhadamente no quarto capítulo deste trabalho.

O intuito de não utilizar categorias de análise e sim eixos temáticos justifica-se devido à multiplicidade e à complexidade dos dados coletados, o que para nós pareceu mais adequado, visto os eixos possuírem um caráter mais aberto que as categorias. Com isso, também buscávamos liberdade para estabelecer movimentos que contemplassem toda a diversidade das informações oriundas dos questionários, fotografias, diários de bordo, filmagens, documentos, entrevistas etc.

Uma ressalva importante, alguns encontros acabaram assumindo/abarcando outros temas, mesmo iniciados com um objetivo previamente definido e um roteiro planejado. Isso justifica o porquê de na análise alguns encontros acabarem compondo dois ou mais grupos temáticos.

\begin{tabular}{|l|l|}
\hline $\begin{array}{l}\text { Encontros de } \\
\text { embasamento teórico } \\
\text { e metodológico }\end{array}$ & $\begin{array}{l}\text { Aqui concentramos os encontros de formação continuada } \\
\text { em que oportunizamos o acesso à reflexão teórica sobre saberes } \\
\text { científicos, a Pedagogia da Comunicação e os processos de } \\
\text { educação com e para mídias. }\end{array}$ \\
\hline $\begin{array}{l}\text { Encontros de } \\
\text { construção de } \\
\text { pedividades } \\
\text { (sequências } \\
\text { didáticas) }\end{array}$ & $\begin{array}{l}\text { Nos encontros deste grupo buscamos exercer uma prática } \\
\text { pedagógica fundamentada nas teorias trabalhadas nos encontros } \\
\text { do grupo anterior, assim concentramos atividades de preparação } \\
\text { das sequências didáticas com as professoras e o desenvolvimento } \\
\text { delas com as professoras-pesquisadoras e as crianças, as } \\
\text { reflexões e as constatações realizadas pós-atividade. }\end{array}$ \\
\hline
\end{tabular}




\begin{tabular}{|l|l|}
\hline $\begin{array}{l}\text { Encontros de } \\
\text { avaliação de } \\
\text { atividades }\end{array}$ & $\begin{array}{l}\text { Nos encontros elencados neste grupo, nosso intuito foi } \\
\text { estabelecer processos avaliativos de três naturezas: avaliação } \\
\text { diagnóstica, avaliação processual e, por último, avaliação final. }\end{array}$ \\
\hline $\begin{array}{l}\text { Encontros de } \\
\text { socialização das } \\
\text { atividades de } \\
\text { pesquisa e } \\
\text { intervenção }\end{array}$ & $\begin{array}{l}\text { Atendendo a uma disposição da natureza da pesquisa } \\
\text { operacionalizada (pesquisa intervenção) e da modalidade eleita } \\
\text { para a coleta e a análise de dados (pesquisa ensino), neste grupo } \\
\text { concentramos os encontros em que fizemos a devolutiva dos } \\
\text { processos desenvolvidos às professoras, à comunidade escolar e } \\
\text { aos pais. }\end{array}$ \\
\hline $\begin{array}{l}\text { Encontros de } \\
\text { integração e } \\
\text { confraternização }\end{array}$ & $\begin{array}{l}\text { Neste grupo apresentamos alguns encontros que mesmo } \\
\text { permitiram conhecer melhor as dinâmicas da escola lócus da } \\
\text { pesquisa: aniversários, festas temáticas, datas comemorativas. }\end{array}$ \\
\hline
\end{tabular}

